Canadian Science Publishing

Canadian Journal of Earth Sciences Revue canadienne des sciences de la Terre

\title{
Slipstream: an Early Holocene Slump and Turbidite Record from the Frontal Ridge of the Cascadia Accretionary Wedge off Western Canada and Paleoseismic Implications
}

\begin{tabular}{|r|l|}
\hline Journal: & Canadian Journal of Earth Sciences \\
\hline Manuscript ID: & cjes-2014-0131.R1 \\
\hline Manuscript Type: & Article \\
\hline Date Submitted by the Author: & $01-$ Apr-2015 \\
\hline Complete List of Authors: & $\begin{array}{l}\text { Hamilton, T.S.; Camosun College, Chemistry and Geoscience } \\
\text { Enkin, Randolph; Geological Survey of Canada, } \\
\text { Riedel, Michael; Geological Survey of Canada, } \\
\text { Rogers, Garry; Geological Survey of Canada, } \\
\text { Pohlman, John; U.S. Geological Survey, } \\
\text { Benway, Heather; Woods Hole Oceanographic Institution, }\end{array}$ \\
\hline Keyword: & $\begin{array}{l}\text { Cascadia Subduction Zone, paleoseismology, 14C age model, British } \\
\text { Columbia, megathrust earthquake }\end{array}$ \\
\hline
\end{tabular}

\section{SCHOLARONE}

Manuscripts 


\section{Slipstream: an Early Holocene Slump and Turbidite Record from the Frontal \\ Ridge of the Cascadia Accretionary Wedge off Western Canada and Paleoseismic}

\section{Implications}

T. S. Hamilton ${ }^{1}$, Randolph J. Enkin ${ }^{2}$, Michael Riedel ${ }^{2}$, Garry C. Rogers ${ }^{2}$, John W. Pohlman ${ }^{3}$, and Heather M. Benway ${ }^{4}$

1) Dept. of Chemistry and Geoscience Camosun College 3100 Foul Bay Rd.

Victoria, B.C. V8P 5J2

Canada

2) Geological Survey of Canada - Pacific

P.O. Box 6000

Sidney, B.C. V8L 4B2

Canada

3) U.S. Geological Survey

Woods Hole Coastal and Marine Science Center 384 Woods Hole Rd.

Woods Hole, MA

USA

4) Woods Hole Oceanographic Institution

Woods Hole, MA 02543-1539

U.S.A.

Corresponding Author: Randy Enkin, P.O. Box 6000, Sidney, B.C. V8L 4B2, Canada telephone: 250-363-6431, fax: 250-363-6565, e-mail: renkin@nrcan.gc.ca 
Abstract: Slipstream Slump, a well-preserved $3 \mathrm{~km}$ wide sedimentary failure from the frontal ridge of the Cascadia accretionary wedge $85 \mathrm{~km}$ off Vancouver Island, Canada, was sampled during CCGS Tully cruise 2008007PGC along a transect of five piston cores. Shipboard sediment analysis and physical property logging revealed 12 turbidites interbedded with thick hemipelagic sediments overlying the slumped glacial diamict. Despite the different sedimentary setting, atop the abyssal plain fan, this record is similar in number and age to the sequence of turbidites sampled farther to the south from channel systems along the Cascadia Subduction Zone, with no extra ones present in this local record. Given the regional physiographic and tectonic setting, megathrust earthquake shaking is the most likely trigger for both the initial slumping and subsequent turbidity currents, with sediments sourced exclusively from the exposed slump face of the frontal ridge. Planktonic foraminifera picked from the resedimented diamict of the underlying main slump have a disordered cluster of ${ }^{14} \mathrm{C}$ ages between 12.8 and $14.5 \mathrm{ka}$. For the post-slump stratigraphy, an event-free depth scale is defined by removing the turbidite sediment intervals and using the hemipelagic sediments. Nine ${ }^{14} \mathrm{C}$ dates from the most foraminifera-rich intervals define a nearly constant hemipelagic sedimentation rate of 0.021 $\mathrm{cm} / \mathrm{yr}$. The combined age model is defined using only planktonic foraminiferal dates and Bayesian analysis with a Poisson-process sedimentation model. The age model of ongoing hemipelagic sedimentation is strengthened by physical properties correlations from Slipstream events to the turbidites for the Barkley Canyon site $40 \mathrm{~km}$ south. Additional modelling addressed the possibilities of seabed erosion or loss and basal erosion beneath turbidites. Neither of these approaches achieves a modern seabed age when applying the commonly used regional marine ${ }^{14} \mathrm{C}$ reservoir age of 800 years ( $\triangle \mathrm{R}=400$ years). Rather the top of the core appears to be 400 years in the future. A younger marine reservoir age of 400 years ( $\Delta \mathrm{R}=0$ years) brings the top to the present and produces better correlations with the nearby Effingham Inlet paleo-earthquake chronology based only on terrestrial carbon requiring no reservoir correction. The high resolution dating and facies analysis of Slipstream Slump in this isolated slope basin setting demonstrates that this is also a useful type of sedimentary target for https://mc06.manuscriptcentral.com/cjes-pubs 
sampling the paleoseismic record in addition to the more studied turbidites from submarine canyon and channel systems. The first 10 turbidites at Slipstream Slump were deposited between 10.8 and $6.6 \mathrm{ka}$, after which the system became sediment-starved and only 2 more turbidites were deposited. The recurrence interval for the inferred frequent Early Holocene megathrust earthquakes is $460 \pm 140$ years, compatible with other estimates of paleoseismic megathrust earthquake occurrence rates along the subduction zone.

Keywords: Cascadia Subduction Zone, paleoseismology, 14C age model, British Columbia, megathrust earthquake 


\section{Introduction}

The Pacific coast of Canada off Vancouver Island is prone to periodic large megathrust earthquakes due to its location at the northern end of the Cascadia subduction zone. There are sedimentological and historic records of the last such event in 1700 AD (Satake et al., 1996; Atwater et al., 2005), and earlier events every few hundred years. The sedimentological events interpreted as evidence for megathrust earthquakes are offshore turbidite deposits and coastal subsidence events (Adams, 1990; Clague et al., 2000; Goldfinger et al., 2003; 2012). Much of this information, particularly for paleoseismicity prior to $1700 \mathrm{AD}$, comes from the central and southern portion of Cascadia and it remains to be shown whether these identified ruptures involve the northern part of the Cascadia subduction zone and whether there are any additional events that only rupture a northern segment. Sedimentological records from Effingham Inlet on Vancouver Island (Dallimore et al., 2008; Enkin et al., 2013) and Barkley Canyon (Goldfinger et al., 2012) suggest that previously identified Holocene megathrust events involve the full length of the Cascadia Subduction Zone. The deep marine turbidite record farther south off Oregon and Washington (Griggs and Kulm, 1970; Goldfinger et al., 2012) is augmented here, by comparable sediment records to the west of Vancouver Island, to facilitate earthquake preparedness and to generate more accurate risk calculations for northern Cascadia. The frequency of megathrust ruptures and tsunamis generated off any segment of coastline affects the seismic hazard calculated for the nearby region. Thus it is important for society to correctly identify the rate of megathrust events affecting each region.

From the inception of this project, we recognized the importance of a series of small slumps from the frontal ridge as a unique environment to study deformation, gas hydrate dynamics and the sedimentary record at the leading edge of the Cascadia Subduction Zone. This study addresses the timing of these slumps, their relationship to longer term frontal ridge growth and the paleoseismic record. Similarly, Cascadia Hydrate Ridge Basin West cores were collected in 2002 to investigate slope 
failures related to hydrate destabilization but were demonstrated instead to record earthquakes (Goldfinger et al., 2012; Patton et al., 2013). This type of paleoseismic analysis depends crucially on finding the restricted depositional environments with sedimentary processes that are capable of recording megathrust earthquakes. From the Juan de Fuca Strait to the north there is little modern sediment accumulation due to few local sources during modern sea level highstand. Most of the seabed is in sedimentary hiatus following deglaciation (Cosma et al., 2008; Clague and James, 2002; Pohlman et al, 2013). The downslope reworking means that the most likely places to find Holocene records of slope failure are in slope basins and active submarine canyon systems eroded into the continental slope. Elsewhere, local coarse grained sediment sources to become remobilized in megathrust events are lacking, so the seabed captures only hemipelagic sedimentation or is in hiatus. At Slipstream Slump, the frontal ridge and the failure ampitheater restrict and isolate the sediment source in a very useful way in space and time to form a bipartite sedimentary record with a predominant background of ongoing hemipelagic deposits punctuated by episodic turbidites. It is the clarity of the turbidites and the utility of the thick interlayered hemipelagics that provide the best type of sedimentary system to capture and precisely define the paleoseismic record in a similar fashion to the record at Hydrate Ridge (Goldfinger et al, 2012). Our combined approach of using cores to provide ground truth for the seismic stratigraphy was able to isolate this small but significant target. Random coring will not suffice, as much of the abyssal plain has the hemipelagic muds but few turbidites and particular localities like the smaller Orca slump $8 \mathrm{~km}$ to the south has reworked Pleistocene slump debris at the seabed with little post-slump sediment accumulation atop its debris lobe in the past $5 \mathrm{ka}$ (Haacke et al, 2008; Core 2008007PGC008).

During research cruise 2008007PGC in August 2008 aboard the CCGS John P. Tully, we collected piston cores at 25 sites from the North American continental slope and eastern edge of the Juan de Fuca Plate off the Canadian portion of Cascadia (Fig. 1a). One purpose of the cruise was to characterize the sediments hosting gas hydrate deposits and to assess the role of gas hydrates in altering sediment 
properties and affecting the nature of the submarine slope failures from the frontal ridge of the continental slope. Most cores were taken at or near active seabed methane vents (Riedel et al., 2002; 2006), or at Barkley Canyon (Pohlman et al., 2005, 2009). The margin in this region consists of a series of active frontal ridges separated from the accretionary prism to the east (Fig. 1d). This frontal ridge features several slumps and slides (Fig. 1b), which provide ideal traps for locally derived sediments. We cored (Haacke et al., 2008, Pohlman et al., 2008, Enkin et al., 2010) across 3 largescale, morphologically youthful, slump features originating from the frontal ridge segments of the continental slope (Davis and Hyndman, 1989).

The first core site out on the abyssal plain not only pierced the slump, but revealed a similar sequence of turbidites to those observed along the eroded channels cut into the continental slope farther south along the Cascadia margin (Griggs and Kulm, 1970; Goldfinger et al., 2012). We then performed a transect of five cores to study the facies descending the frontal ridge to understand the sequence of events spanning the initial failure and subsequent turbidites. In this paper, we discuss the setting, sedimentology and age constraints for a sequence of turbidites that we relate to paleo-seismicity during the last ten thousand years from this northern portion of the Cascadia subduction zone.

\section{Methods}

Piston cores using $7 \mathrm{~cm}$ diameter acrylic liners were collected aboard the CCGS Tully using an 820 $\mathrm{kg}$ drive weight dropped from a height of $10 \mathrm{~m}$ above the seafloor and tripped by a trigger core for additional description and sampling as well as to ensure seabed recovery. Positions were taken from on board GPS and with timed fixes for core on and off bottom with wire out and wire angle recorded. Piston cores were recovered up to $7.2 \mathrm{~m}$ long, while trigger cores were less than $1 \mathrm{~m}$ long. A NNE to SSW transect downhill across Slipstream Slump (Fig. 1c) cored five sites (Table 1). Cores 25 and 11 
are from the headwall scar, Core 10 was collected from a small intra-slump basin atop the toe of the slump, and Cores 9 and 7 come from the abyssal plain beyond the outermost cohesive slump block.

The cores were immediately split aboard ship following recovery to permit sampling of fresh pore waters by aspiration to rhizones, with subsequent shipboard analyses of chloride and sulphate concentrations by ion chromatography. Split cores were photographed and physical properties were measured along a core track (1-2 cm: magnetic susceptibility - Bartington MS2E; 5-10 cm: electrical resistivity - lab-designed $4 \mathrm{~mm}$ Wenner probe; seismic p-wave velocity - lab-designed $7 \mathrm{~cm}$ piezoelectric crystal fork; shear strength - SoilTest CL700 pocket penetrometer and WykehamFarrance motorized vane). Lithological descriptions were made shortly afterwards utilizing both core halves as available. Sedimentological interpretations helped guide further coring locations during the cruise. Core descriptions were based on visual measurements, Munsell soil colours, structures, grain size variation, texture, degree of stiffness, odour, diagenetic indicators, reaction to $3 \mathrm{M}$ hydrochloric acid $(\mathrm{HCl})$, smear slides, and sub-samples taken for $+63 \mu \mathrm{m}$ sand separates. The dried sand fractions were visually examined and magnetically separated with a hand magnet to investigate the source of peaks in the magnetic susceptibility logs. The primary magnetic variations were due to individual magnetite grains or magnetite-bearing igneous rock fragments from ice rafted debris (IRD) or older turbidites from upslope, and introduction of younger diagenetically grown greigite or other ferromagnetic iron sulphides associated with of the anaerobic oxidation of methane AOM (Novosel et al., 2005, Pohlman et al., 2013) nearby in the frontal ridge. Sandy layers were also subsequently analysed to characterize their grain size distributions and bulk X-ray diffraction (XRD) mineralogy at the Geological Survey of Canada labs in Ottawa using semi-quantitative Reitveld analyses of bulk sand separates using their XRD peak intensities. This information served to verify a common source for the slump and lithic sands as the local deglacial diamicton capping the frontal ridge but revealed no details relevant to the paleoseismic story. 
For radiocarbon dating, 2 to $4 \mathrm{~cm}$ intervals (Table 2) of fine grained muds with detectable carbonate-acid reactions were cleaned and sieved with deionized water, and coarse fractions $(>63 \mu \mathrm{m})$ were dried at $60^{\circ} \mathrm{C}$. Specimens of the planktonic foraminifer species Neogloboquadrina pachyderma, both dextral (right-coiling) and sinistral (left-coiling) variants, were picked from the 150-465 $\mu \mathrm{m}$ size fraction. $N$. pachyderma (Ehrenberg, 1861) is a non-spinose, non-symbiotic planktonic foraminifer that dominates subpolar and polar water masses but can also be found in smaller abundances in subtropical and tropical waters, and typically prefers lower sea surface salinities influenced by rainfall or runoff. The sinistral variant is mostly found in polar waters with annual average sea-surface temperatures $<7-9^{\circ} \mathrm{C}$, while the dextral variant prefers slightly warmer sea surface temperatures $\left(>8^{\circ} \mathrm{C}\right)$ (Hilbrecht, 1996; Kucera et al., 2005; Darling et al., 2006). The depth habitat of $N$. pachyderma varies regionally. Sediment trap data from the northeast Pacific (Reynolds and Thunell, 1986) indicate that the relative abundance of the two variants is strongly tied to seasonal temperature changes and thermocline depth and structure, with dextral variants preferring a more stratified upper water column with a shallower thermocline. The abundance ratio of the dextral and sinistral variants in the study region likely reflects the degree of mixing between subtropical and subpolar waters of the North Pacific. During Holocene intervals in the cores studied, the sinistral variant is dominant with a ratio of about 2:1 (sinistral:dextral) at all levels sampled. $N$. pachyderma in similar coiling proportions, collectively make up $\sim 75-90 \%$ of the foraminiferal assemblage in other ${ }^{14} \mathrm{C}$-dated samples from the Cascadia Subduction Zone (Goldfinger et al., 2012). Benthic foraminifera are less favoured in this muddy, sheltered, North Pacific, foreslope-foredeep abyssal environment, and appear to be limited to the tractive channels that incise the continental slope and shallower slope and shelf settings having abundant sand at the seabed. Due to the dominance of $N$. pachyderma variants in the planktonic foraminferal assemblage of this region and its use in prior paleoseismic studies, it was the preferred species for this work.

Mixed N. pachyderma subsamples (dextral and sinistral), ranging from 1.5 to $6.5 \mathrm{mg}$, were analyzed at the National Ocean Sciences Accelerator Mass Spectrometry (NOSAMS) Facility at the Woods Hole https://mc06.manuscriptcentral.com/cjes-pubs 
Oceanographic Institution. Calendar ages were converted from raw ${ }^{14} \mathrm{C}$ ages using the Marine13 calibration curve (Reimer et al., 2013), with age modelling discussed later in this paper. Note that Marine13 makes significant changes relative to Marine09 only to the Pleistocene portion of the calibration curve. This calibration was accomplished with the program OxCal version 4.2.3 (Bronk Ramsey, 2009).

\section{Results}

\section{Sedimentation along Northern Cascadia}

Most cores taken on the continental slope off the glaciated Canadian coastline are dominated by accumulation of Pleistocene sediments, as the lithofacies and radiocarbon ages indicate (Cosma et al., 2008; Pohlman et al., 2013). The dominant lithologies include deglacial rock flour clays, silts and diamictons with sporadic layers of sand- to cobble-sized ice rafted debris (IRD) and finely laminated to gradationally interstratified hemipelagic material. Microfossils, chiefly planktonic foraminifera and diatoms, are present in low but useable concentrations (a few hundred tests per $10 \mathrm{~cm}^{3}$ sample). Most sediment at the seafloor on the lower continental slope dates between $13-14 \mathrm{ka}{ }^{14} \mathrm{C}$ (Table 2 ). The latest Pleistocene accumulation is thick ( 300 m of deposition since $600 \mathrm{ka}$ from the nearby IODP Expedition 311 holes, Riedel et al., 2006). These deglacial sediments form the crest of the frontal ridge and underlie most of the lower continental slope seabed such as that around Bullseye Vent (Pohlman et al, 2013; and our cores 2008007PGC005 and -006).

The lower continental slope west of Vancouver Island is kept relatively free of Holocene sediment accumulation because the west coast of Vancouver Island has only a few short system streams, there is little coastal sediment to erode and the broad continental shelf is mostly a lag system with some storm reworking but little new sediment throughput in this highstand setting. Outside Slipstream Slump, 
including those sampled for the present study, most cores have thin $(<20 \mathrm{~cm})$, soupy, olive-coloured tops consisting of a weathered and reworked layer and confirming that coring captured the modern seabed. Due to the slope, slight bottom currents, local bathymetric relief and low rates of ongoing hemipelagic sedimentation, there is little if any modern or post-deglacial sediment accumulation on the continental slope except in rare channels which follow structural troughs or the local slope basins between or in front of ridges on the accretionary wedge where the channels terminate. For a rough idea of how little of the continental slope has modern deposition, note that channel and trough areas on Fig. $1 \mathrm{~b}$ comprise only a few percent of the seabed. Because of this, IRD-bearing diamicts are the dominant uppermost lithology of the continental slope at these northerly latitudes along the Cascadia subduction zone as confirmed by paired trigger cores with identical recovery to the seabed. We also cored at the northern flank of Barkley Canyon (2008PGC007024) near a site of gas hydrate outcrops, where Ocean Networks Canada (ONC) installed long-term observatory instrumentation. There we recovered eroded glauconite rich sands from the eroded canyon wall adjacent to the hydrate outcrop. This and the Barkley Canyon cores downslope near the canyon thalweg with the turbidite record (Goldfinger et al, 2012) demonstrate the restricted lateral extent of modern sediment accumulation. From here farther south to the Juan de Fuca Canyon (Goldfinger et al., 2012) most of the seabed has no delivery of coarse modern sediment or useful turbidites for paleoseismic work as the older coring record from the University of Washington indicates (Atwater et al, 2014).

Against this relict background of deglacial sedimentation and effectively a bypass margin during this modern highstand systems tract, the setting of Slipstream Slump and its sedimentary facies is unusual. It provides a special opportunity to examine the Early Holocene paleoseismic record for this northerly part of the Cascadia subduction zone. The frontal ridge of the Cascadia accretionary prism at Slipstream Slump rises $500 \mathrm{~m}$ above the abyssal plain. The slide-headwall scarp is aligned WNW-ESE, parallel to the ridge crest, and is bounded by two perpendicular walls $3.3 \mathrm{~km}$ apart (Fig. 1c), analogous to the bounding normal faults described by Lopez et al. (2010) for the next prominent frontal-ridge 
slide located $10 \mathrm{~km}$ to the north (Fig. 1b). The seawards-facing headwall scarp of the frontal ridge exposes older Pleistocene sediments. The steep topography of the frontal ridge adjoining the debris fan of a single local failure constitutes a short or condensed turbidite system. The entire path is less than a few kilometers in length from the proximal region with cohesive mud breccias to the distal gentle silt clouds which drape the debris fan of the initial slump (Fig. 1c). There is no channel or canyon across Slipstream Slump to direct turbidity current flow although there are nearby canyons to both sides. Those systems appear to be sediment starved and lack the sediment waves which are developed at the mouth of Barkley Canyon $40 \mathrm{~km}$ away. The toe of the headwall has scarps from rotated failure blocks to act as small catchment basins. All of the conversion of height to flow velocity happens very close to the $40^{\circ}$ headwall scarp. Only fine grained, flat based, thin layers of upwards fining sand and silt are deposited out on the gentle slope $\left(<1^{\circ}\right)$ of the mud draped fan. There is no evidence of high energy coarse sediment or channelized flow to disturb the interlayers of hemipelagic mud off the toe of the frontal ridge. This setting, while it does generate and deposit turbidites, is very different from the long, steep walled submarine canyons with eroded channel floors and distinctive thalwegs that incise the continental slope.

\section{Pore Water Geochemistry}

The concentration of chloride from 56 sediment pore water samples extracted from the cores is 551 $\pm 10 \mathrm{mM}$ (Fig. 2a), which is indistinguishable from seawater $(\sim 559 \mathrm{mM})$ or pore fluids analyzed at nearby Site U1326 during IODP Expedition 311 (Fig 1a; Riedel et al., 2007; Spence et al., 2000). During the formation of gas hydrate in marine systems, seawater ions are excluded from the clathrate structure. Initially, the surrounding residual pore fluids are of elevated concentration, but in time the excess ions diffuse away leaving gas hydrate bathed in seawater salinity fluids. When gas hydrate dissociates, fresh water is released and the surrounding pore fluids thus attain a lower salinity. The 
absence of elevated chloride related to recent gas hydrate formation or depleted chloride related to gas hydrate dissociation (Ussler and Paull, 2001) indicates none of the cored material contained gas hydrate at the time of recovery.

Sulfate concentrations for all cores range from $18.1 \mathrm{mM}$ to $28.1 \mathrm{mM}$ (Fig. 2b). There is a clear trend that the most distal cores with finer grained and more reworked slump materials have higher initial sulphate concentrations (increasing trend from Core 10-7-9) downslope (fig. 2b). The highest sulfate concentration from each core is from the shallowest sediment depth and it is only slightly less than the concentration of seawater sulfate $(\sim 28.9 \mathrm{mM})$. Sulfate concentrations decrease gradually with depth (Fig. 2b). Linear extrapolations of the top measured sulfate concentrations always reach seawater concentration within $\pm 20 \mathrm{~cm}$ of the top of the core.

Decreasing downcore sulfate concentration is due to in-situ bacterial sulfate reduction during the oxidation of organic matter (Eq. 1) or the anaerobic oxidation of methane (AOM; Eq. 2).

$$
\begin{aligned}
& 2 \mathrm{CH}_{2} \mathrm{O}+\mathrm{SO}_{4}{ }^{2-} \rightarrow \mathrm{HS}^{-}+\mathrm{HCO}_{3}^{-}+\mathrm{CO}_{2}+\mathrm{H}_{2} \mathrm{O} \\
& \mathrm{CH}_{4}+\mathrm{SO}_{4}{ }^{2-} \rightarrow \mathrm{HS}^{-}+\mathrm{HCO}_{3}^{-}+\mathrm{H}_{2} \mathrm{O}
\end{aligned}
$$

Along this portion of the Cascadia margin, terrestrial-derived lithogenic magnetic minerals that were transported and deposited offshore as IRD or as terrigenous bedload farther south in Cascadia are abundant (Chamov and Murdmaa, 1995). Sulfides produced during organic matter and methane oxidation react with the iron oxides such as hematite $\left(\mathrm{Fe}_{2} \mathrm{O}_{3}\right)$ or magnetite $\left(\mathrm{Fe}_{3} \mathrm{O}_{4}\right)$ in the mechanically weathered lithogenic material to form greigite $\left(\mathrm{Fe}_{3} \mathrm{~S}_{4}\right)$ and eventually pyrite $\left(\mathrm{Fe} \mathrm{S}_{2}\right)$ where sulfate is limited or methane dominates (Novosel et al., 2005). Because the continental slope of the Cascadia margin contains a limited amount of sedimentary organic matter (Kaneko et al., 2010), the primary driver of sulfide production is AOM (Pohlman et al., 2013). Thus, the presence of iron sulfides in sediments in the Slipstream Slump material indicates an active or former association of that sediment with the anaerobic oxidation of methane (e.g., Pohlman et al., 2013). In this study, the diagenetic iron sulfide greigite was observed within the sulfate zone where AOM does not presently occur. The 
separation of greigite from the AOM zone thus indicates the greigite was reworked and translocated downslope during submarine mass failures such as slumps and turbidites or the flux of methane at this location has decreased (Hensen et al., 2003).

The presence of reworked greigite among the sand population corroborates the diagenetically altered frontal ridge as being the sediment source and implies that substantial time has passed since the diamict deposition for anaerobic diagenesis to occur (thousands of years since deglaciation). Given the low organic matter content of this offshore hemipelagic sediment (Pohlman et al., 2013), the decrease in sulfate concentration down the cores requires considerable time and is a qualitative indication that these sediments and the slumps are at least 5000 years old (Pohlman et al., 2008). Radiocarbon analysis of reworked material from the slumps allowed us to obtain a stratigraphically deeper-time constraint for the age of the sediments and slumps.

\section{Core Transect across Slipstream Slump and Sediment Facies}

Five principal sedimentary facies represent variations in transport and depositional processes: 1) hemipelagic mud, 2) turbidite sands and silts, 3) remoulded and reworked slump materials, 4) deglacial diamict and IRD, and 5) dense glauconitic microfossil ooze, are observed in the Slipstream Slump cores (Fig. 3). The first 3 facies are interlayered and overlie the last 2 facies.

\section{Hemipelagic Mud}

Cores 10, 9 and 7 are capped with about $2 \mathrm{~m}$ of Holocene sediments, including sparsely microfossilbearing hemipelagic mud (Fig. 3a). This is about 2 times the typical Holocene sedimentation rate found in the thalwegs of Turbidite channels (Goldfinger et al, 2012), and is significant for the method of age modelling. Local seismic profiles (Haacke et al, 2008) and Figure 1d show supertenuous drape. 
It is possible that the enhanced mud accumulation is due to downslope reworking of hemipelagic sediments, either gradually or suddently as fine turbidite tails. These sediments are characterized by soft, low strength, olive green to grey, super-hydrous mud of silt- to clay-sized terrigenous detritus and biogenic ooze. Occasional dispersed or thin layers of sand grain-sized foraminifera appear as lighter coloured, wetter, sandy bands with stronger reaction to $\mathrm{HCl}$. Hemipelagic mud tends to be finely laminated to massively-bedded in layers from less than a few $\mathrm{cm}$ to more than $45 \mathrm{~cm}$ thick in the shallower part of the stratigraphic column. They usually have low magnetic susceptibilities between 0.4 and $0.7 \times 10^{-3} \mathrm{SI}$. Electrical resistivity is typically 0.36 to $0.40 \Omega \cdot \mathrm{m}$. Punch penetrometer compressive strength is typically 1.0 to $3.5 \mathrm{~N} \cdot \mathrm{m}$. P-wave velocity is marginally higher in these muds than pure sea water here at 1500-1520 m/s, but remains typical of superhydrous muds. Foraminifer rich bands from these muds were selected to provide the best material (abundant and least reworked) for ${ }^{14} \mathrm{C}$ dating of ongoing sedimentation rates for the background enveloping hemipelagic section. The abundance of this thick hemipelagic mud section draping the older slump dictated the initial coring strategy to establish local post-slump sedimentation rates in order to date the older slump.

\section{Turbidites and Slide Debris}

The hemipelagic Holocene mud is interrupted at numerous horizons by Holocene turbidites (Fig. 3a). The discovery during the cruise of this long intermittent turbidite record interlayered with thick, undisturbed hemipelagic muds created a new objective with the possibility of pulling out a megathrust event record from the ongoing mud accumulation. The occurrence of graded sand and silt beds is not unique, but the thick intervening mud sections and the isolated slope basin setting without a channel system is rather special. The coarsest turbidites from proximal settings up near the headwall scar (Cores 11 and 25, Fig. 1c) and bigger failure events (near the base of cores 10, 7 and 9, Fig. 1c) contain mud clasts and correspond to Bouma's A facies (Bouma 1962; Bouma et al., 1985) or Lowe's S1 facies 
(Lowe, 1986). Turbidites are recognized by their coarse particle sizes, silts, sands and larger clasts (sand balls or rip up clasts of mud), and by normal grading (fining upwards sequences, FUS) observed both lithologically and in the physical properties logs. In this study, the turbidites are bedded on scales of several millimeters to several tens of centimeters. These coarser lithologies and their grading can be seen visually in the cores, in comparative sand separates and in the magnetic susceptibility logs all of which show sharp bases (non-erosive) with upwards successions of exponentially decreasing grain size. These sediments have a range of particle size distributions and mean grain sizes depending on what part of the turbidite sequence is observed (Bouma, 1962; Bouma et al., 1985). The coarser sediments (Bouma's A, B and C facies) exhibit decreasing grain size and thickness from proximal sands to distal silts respectively (Core 10 to 7 to 9). For some of the turbidites, this includes some Bouma D turbidite tail. The Bouma D-E transition is estimated to occur where physical properties fall back to the local hemipelagic mud baseline. This is a major advantage in having the multiparameter physical properties logs for these cores, and to having measured the profiles both on whole and split core prior to any sampling for radiocarbon. This is significant as our intervening hemipelagic facies (Bouma facies E) layers are used for foraminiferal sampling to date ongoing sedimentation wherever this could be best done between turbidite deposits. The undisturbed nature and thickness of the enveloping mud section permits the background hemipelagic sedimentation to be dated, as opposed to a one-by-one bracketing of turbidite layers and event dating which is the method of choice in submarine canyons with their thickness dominated by the coarse turbidites (Goldfinger et al, 2012).

Petrographic observations revealed that sand fractions of turbidites contain variable proportions of diatoms, foraminifera, sand-sized rock fragments and mineral grains. The largest sand grains are plutonic and volcanic rock fragments, typical of local Vancouver Island coastal bedrock sources. Petrographically, all turbidite samples contain traces of magnetite, epidote, glauconite and glass. Both petrographically and according to XRD analyses, the bulk of the sand mineralogy is dominated by quartz with lesser plagioclase and subordinate K-feldspar, amphibole (hornblende), muscovite and 
epidote consistent with IRD sourced from plutonic and volcanic rocks which dominate the bedrock of Vancouver Island $85 \mathrm{~km}$ to the NE. There are traces of diagenetic iron sulfides (greigite, pyrite). The calcite is a mixture of diagenetic carbonate nodules and cements with planktonic foraminifera and rare shell fragments from broken pelecypods and gastropods. The foraminifers tend to be broken, abraded and filled with mud. The mineralogy is consistent with sand reworked from glacial diamictons and reworked planktonic microfossils derived from the seabed upslope as the source region.

The sandier load in the turbidites tends to have more detrital rock and mineral fragments with higher magnetic susceptibilities than the mud background, with peaks from 0.8 to $2.3 \times 10^{-3} \mathrm{SI}$. Electrical resistivity tends to be greater than $0.36 \Omega \cdot \mathrm{m}$ typical of the hemipelagic mud, with peak values above $0.43 \Omega \cdot \mathrm{m}$. This is consistent with the sands being stiffer and drier (having lower water contents) than the hemipelagic muds. Penetrometer strengths in the turbidite-rich sections range from 5 to $7 \mathrm{~N} \cdot \mathrm{m}$. P-wave velocities of the sandy, permeable turbidites tend to be higher than sea water values at $\sim 1540$ $1550 \mathrm{~m} / \mathrm{s}$, showing the influence of sand grains on the bulk velocity. The example shown (Fig. 3a) is from a proximal mud breccia from a basal facies (Bouma A). More distal turbidites farther downslope are more typically graded sand to silt beds (Bouma B). The darker enveloping turbidite matrix has some thin sand lenses near its base below $220 \mathrm{cmbsf}$ and 2-4-cm mud clasts. These post-slump turbidites have a platykurtic grain-size distribution with a grain size mode near $0.06 \mathrm{~mm}$ and as much as $5 \%$ coarser grains extending to greater than $0.15 \mathrm{~mm}$ (e.g., fine slightly sandy silts. This grain size distribution contrasts with those from the underlying main slump (Fig. 3), in that the sandy to silty turbidites are distinctly bimodal with a second coarser sand fraction between 0.065 and $0.11 \mathrm{~mm}$, i.e., fine to medium sand. The bimodal nature here is due to the presence of mud clasts carrying their own finer primary grain size distribution in addition to the sands which were sorted during turbidite transport and deposition. Other than these general observations contrasting sand transport during the highly energetic and short lived pulses of the main slump, or proximal scarp face failures from 
subsequent and distal turbidite events, grain size data for individual Holocene turbidite layers reveal no additional useful information for the paleoseismic story.

\section{Slipstream Slump Facies}

The main Slipstream Slump event (Fig. 3b, c) is represented in Core 25 below 68 cmbsf, in Core 11 above 220 cmbsf, in Core 10 below 210 cmbsf, in Core 9 below 320 cmbsf and in Core 7 below 420 cmbsf. The lithology of this slump material is a gritty clay with hard, dense, dewatered, gritty clay clasts in a softer, more hydrous clayey matrix, capped by an inclined bed of moderately well sorted, medium-grained muddy sand. Conventionally in sedimentology, this would be described as proximal turbidites of Bouma-facies A and B or the basal S1-S3 coarse grained beds of Lowe (1986). Some of the clay balls amid the coarser material are partially cemented and contain mottled, black, fine grained, magnetic iron sulphide clots (denoted with the symbol $b$ in Fig. 3b, Core 25) which are derived from their diagenetically altered source beds atop the frontal ridge. The source for these hard, dark, magnetic clay clasts is glaciomarine diamict altered by AOM, as described elsewhere for the North Pacific (Barnes et al., 1998; Cragg et al., 1996) and nearby Bullseye vent (Pohlman et al., 2013; Hamilton et al., 2010).

Deeper in this core are cohesive clasts to tens of centimeters in size cut by inclined fractures crossing the entire core. There is also some inclined angular void space in this coarse blocky slump material (see Fig. 3b, Core 25 near $71 \mathrm{cmbsf}$ ) along with deformation, shear and folding of the underlying substrates (see Fig. 3c, Core 11 near 224 cmbsf). The magnetic susceptibility of this slump facies has a background level of about $1.5 \times 10^{-3} \mathrm{SI}$ with peaks for sands of 2.0 to $3.0 \times 10^{-3}$ SI due to detrital magnetite and lithic fragments and the horizons with diagenetic iron sulphide as high as $4.2 \times 10^{-3} \mathrm{SI}$. Electrical resistivity is usually in the range from 0.53 to $0.91 \Omega \cdot \mathrm{m}$ but can be as low as $0.38 \Omega \cdot \mathrm{m}$ in dehydrated, remoulded clay clasts in Core 11 (Fig. 3c). Penetrometer strengths are about https://mc06.manuscriptcentral.com/cjes-pubs 
24-36 $\mathrm{Nm}$ for typical clayey diamict but can be as low as $5 \mathrm{Nm}$ in softer super-hydrous matrix or as hard as $50 \mathrm{Nm}$ in remoulded clasts. Shear strength is similarly variable, typically in the range of 270$310 \mathrm{Nm}$ but as low as $40 \mathrm{Nm}$ in the super-hydrous matrix as per Cores 9, 11 and 25 (Fig. 3c). The P-wave velocities are typically $1510-1625 \mathrm{~m} / \mathrm{s}$ as per Core 10,9 and 7 but can be as low as low as 1450 $\mathrm{m} / \mathrm{s}$ in the super-hydrous matrix between clasts in the slump Cores 11 and 25 .

\section{Diagenetically Altered Deglacial Diamict}

This facies is the sedimentary cap on much of the accretionary wedge including the frontal ridge. Locally, it is the source of sediments in the Slipstream Slump. Regionally the most widespread and the thickest sediment type, across the entire continental slope, is deglacial diamict from the Wisconsinan ice retreat and melt-down of the Juan de Fuca lobe and glaciers of Vancouver Island (Delthier et al.,

1995; Clague et al., 1982; Hickock et al., 1981). The grey glaciomarine sediments are mostly very finegrained, but within the predominant rock flour clays, they contain graded beds, sand clasts, clay clasts, IRD and interbeds that are richer in planktonic microfossils from plankton bloom events or hiatus in glaciomarine IRD sedimentation. The diagenetically altered glaciomarine sediments also contain blackened zones comprised of disseminated fine-grained iron sulphides, FIS (Hamilton et al., 2010), which include sand sized specimens of greigite with pyrite overgrowths or replacements and microbial carbonate crusts. The diagenesis is stratiform and stratabound for the most part but also occurs along fractures and on the boundaries between clasts; essentially anywhere there is a contrast in permeability. The blackening enhances the porosity differences and makes visible very fine scale laminations on a scale smaller than $1 \mathrm{~mm}$, finer than can be seen within the more uniform matrix or in contrast to gradual changes in the grey colours of the unaffected sediment from the primary depositional fabric. The presence of iron sulfides and carbonate concretions, which form as an imprint of methane venting 
and AOM within sediments, where otherwise AOM was inactive, further supports the conclusion that deglacial diamicts were diagenetically altered prior to translocation by a slump.

Deglacial diamict is locally represented by the uppermost cohesive slide block in Core 25 (Fig. 3b), IODP Leg 311 site U1326 (Fig. 1d) and the entirety of our Cores 2008007PGC005 and -006 from Bullseye Vent which are identical to the diagenetically altered upper $100 \mathrm{~m}$ of IODP Leg 311 site U1327 (Riedel et al., 2006a). Technically the entire length of Core 25 is debris worked down off the headwall scarp following the main slump event, so it is also actually a proximal example of our turbidite facies, but it contains large coherent slump blocks of diamict and older reworked foraminifera (broken, abraded, mud-filled) like those sampled below the failure plane in Core 11. The diamicts from Core 25 are selectively blackened by variable greigite/FIS formed as a by-product of AOM. Signs of this early diagenesis are apparent in the magnetic susceptibility logs. There background values are on the order of $1.25 \times 10^{-3} \mathrm{SI}$ units in the clayey intervals to 2.6 to $3.4 \times 10^{-3} \mathrm{SI}$ in the sandier ones. The sands are magnetite-rich, more diagenetically altered, more porous, and more griegite rich as confirmed by petrography on magnetic separates.

Shear strength in cohesive slide blocks of the reworked glacial diamict is about $160 \mathrm{Nm}$ with an overall range from 90 to $300 \mathrm{Nm}$. Penetrometer strength is 15 to $60 \mathrm{Nm}$, similar to this facies in cores from Bullseye vent where they occur in situ, but here the values are more variable due to the slide and block nature of upper Core 25 as pictured in Fig. $3 b$.

Penetrometer strengths are about 14 to $50 \mathrm{Nm}$ in the coherent diamict slide blocks versus softer matrix with values $<10 \mathrm{Nm}$ indicating some remoulding compared to original depositional strengths. Shear strengths are also highly variable in the slumped materials of Core 25 ranging from 100-340 Nm. P-wave velocity is slightly low in Core 25 at about $1470 \mathrm{~m} / \mathrm{s}$ due to the super-hydrous matrix and possibly some fresh water input from gas hydrate dissociation within the slumped materials (Spence et al., 2000; Lopez et al.; 2010). Electrical resistivity is low in the softer clayey matrix $(<0.58 \Omega \cdot \mathrm{m})$ but 
cohesive and diagenetically altered clasts, especially those containing the fine grained iron sulphide, are more resistive with values $>0.95 \Omega \cdot \mathrm{m}$ due to incipient cementation and porosity loss.

\section{Glauconitic Biogenic Ooze}

Glauconitic biogenic ooze (Fig. 3c) is only recovered at Slipstream Slump from the base of Core 11 (collected from the abrupt decrease in slope at the foot of the slide scar) where it occurs below a folded interface at 241 cmbsf. Here it is an Early Wisconsinan to Latest Pleistocene, dense laminated biogenic ooze. The ooze has a distinctive greenish grey colour $(5 \mathrm{GY}-4 / 1)$ due to the abundance of glauconite which is usually an indicator of lag sedimentation dominated by biogenic rather than terrigenous sources (Bornhold and Giresse, 1984). It usually is most abundant in lowstand or rising systems tracts (Amorosi, 1995) which locally coincides with glacial maximum and deglaciation. Presumably its occurrence in the eroded canyon walls near Hydrate Gulch (our core 2008007PGC024) is similar in age. The green glauconitic sediments are stiffer and drier than any other facies sampled in this study and they exhibit a vigorous reaction to dilute $\mathrm{HCl}$ due to abundant foraminifera. The abundance of microfossils is very evident in the smear slides as is the paucity of quartz and lithic grains. The physical properties are unique and highly distinctive compared to any other lithologies measured. The magnetic susceptibility is very low $\left(0.10-0.210^{-3} \mathrm{SI}\right)$, indicating low magnetite content and variability except for 2 thin lithic sands near 290 and 352 cmbsf which rise up into the ordinary background values for fine terrigenous sediments $\sim 0.40-0.5010^{-3} \mathrm{SI}$. These sands are lithologically distinctive in being quartz- and feldspar- poor but lithic-rich, in direct contrast to the IRD material and our turbidite facies higher in the section. This sandy material probably derives from a higher thrust panel in the frontal ridge, exposing some former abyssal plain materials thrust up near the ridge crest. At the time the wedge shed these rare lithic sands, there was a local terrigenous source, as of yet not covered by the ooze. Arguably, as 
discussed below in the age model, these 2 deeper sands might represent older Pre-Holocene megathrust seismites in contrast to those of the main Holocene section studied here.

The electrical resistivity of the ooze ranges from a low value of $0.4 \Omega \cdot \mathrm{m}$ near the top of this unit to more than $0.65 \Omega \cdot \mathrm{m}$ at the base of the core. While this parameter tends to be variable, influenced by differing water content and fractures, the trend to higher resistivity with depth is one of progressive dewatering and gradual compaction during very slow sedimentation. P-wave velocities in the ooze range from $1450-1585 \mathrm{~m} / \mathrm{s}$, slightly lower than in the diamictons at the top of the same Core 11. Penetrometer strengths increase downwards from 6-30 Nm, as shear strengths increase from 140 to 300 $\mathrm{Nm}$. Both of these trends show increased strength with depth over $<70 \mathrm{~cm}$, parallel to the trend of increasing resistivity and decreasing pore water content. They are particularly significant in that they define a depth of failure and the sole to the Slipstream Slump's basal failure plane. It also seems to indicate that at most the uppermost few tens of $\mathrm{cm}$ are sheared off or involved in the main failure event off the face of the frontal ridge. The ages in the slump itself confirm a restricted range of ages as discussed below.

\section{Summary of Sedimentary Facies}

In summary, the segmented frontal ridge of the Cascadia accretionary wedge west of Vancouver Island (Fig. 1) is a southwest verging thrust anticline with a draping cap of cohesive diamicts and IRD deposited after the Last Glacial Maximum (LGM; Cosma et al., 2008 ), overlying a core region of uplifted and structurally deformed (Riedel et al., 2002; Haacke et al., 2008) stiffer, drier, and denser Pleistocene biogenic ooze. After the Late Wisconsinan (Clague and James, 2002) IRD dump from deglaciation, the ridge crest became normally faulted both along and across strike, subsequently controlling the extent of the slump. The main slump failure plane cut down through the deglacial sediments along a listric normal fault and rode the underlying southwesterly dipping contact with the 
underlying stiffer biogenic ooze. Slipstream Slump failed as a series of coherent outrunner blocks and disaggregated turbidite deposits. After the main slump event, hemipelagic sediments slowly and continuously fell through the water column directly or slid down the frontal ridge slope to accumulate on the seafloor and drape the main slump. These hemipelagic muds also interfingered with occasional intermittent turbidite deposits sourced from the reactivated ridge crest or the oversteepened bare headwall scar $\left(35-40^{\circ}\right)$.

A comparison of the sedimentary observations and physical properties logs from the three distal cores $(10,9$ and 7) at Slipstream Slump reveals an almost perfect 1:1 correlation for the turbidites (Fig. 4). The turbidites are labelled SS1 to SS12 from the top down and the numbers in the white space are uncalibrated ${ }^{14} \mathrm{C}$ ages in their correct as-sampled positions. Turbidite SS12 in our three cores sits immediately above the main Slipstream Slump deposit. There is a character of the sequences to be correlated including turbidite thickness, intervals and gaps between turbidites and packages of turbidites. From SS12 to SS3, the turbidites comprise a high proportion of the total sedimentary thickness $(>30 \%)$. The magnetic susceptibility logs provide the highest resolution data and the clearest distinction between the coarser and more magnetic sandy, graded turbidite layers and the intervening hemipelagic mud with lower background levels of magnetic susceptibility, as discussed in the previous section. The correlation matches in number of events, relative thicknesses of sands and internal character of the magnetic profile. This character tie is particularly apparent for the thickest turbidites and may be a proxy for the duration of shaking or the particular characteristics for the earthquakes they arguably represent as discussed by Goldfinger et al. (2012). Overall the turbidite events are more frequent for the lower portion of the record. The thicknesses of the hemipelagic intervals match as well and the tie is particularly evident for the long hiatus following the big event SS3. SS3 was apparently a large and energetic turbidite, especially visible as a high-amplitude magnetic susceptibility impulse and FUS decay (Fig. 4) indicating a high concentration of lithic grains released from the headwall diamict. In Cores 9 and 10, turbidites SS2 and SS9 (and SS11 in Core 10) do not display significant magnetic 
susceptibility enhancement, but they are recognizable by other lithological and sedimentological contrasts. The turbidites are recognizable in having sand stringers, clasts or graded beds with fining upwards character. While the turbidite thicknesses in the 3 cores are variable, the hemipelagic sediment thicknesses in the outermost Cores 7 and 9 are nearly identical. For turbidites SS3 and deeper, the sand thicknesses all increase distally from 10 through 7. After SS3 there is a long hiatus and SS2 is thickest in the intermediate position core 9 rather than distal 7. This seems to indicate either less vigorous events for SS2 and SS1 or a waning sediment supply as most anything that could be shaken off of the old slide scar had already fallen down. There is apparently missing hemipelagic sediment thickness between turbidites in Core 10 as well as a thin record for events SS11, 10 and 9, which we hypothesize is caused by erosion/ignition at this site during turbidite flow, due to its proximal location. An early recognition of the more complete and correlatable records from Cores 7 and 9 focussed the dating work on those two more distal sites.

Figure 4 also presents our preferred correlation to Barkley Canyon site M9907-09PC (Goldfinger et al., 2012) in a nearby submarine canyon setting as well as to the Effingham Inlet record MD02-2494 from a silled fjord basin (Enkin et al., 2013) along with their uncalibrated ${ }^{14} \mathrm{C}$ ages. These other 2 sites have rather different sedimentology and depositional processes but are nearby enough to all have experienced the same megathrust earthquakes. The detailed correlation to these sites and the age model is presented subsequently.

\section{Radiocarbon Ages}

The N. pachyderma foraminiferal samples collected from hemipelagic sediments consistently exhibited 2:1 ratios of the sinistral to dextral variants. These same species were selected and sampled throughout all cores and stratigraphic levels sampled. For the Holocene post-slump interval containing turbidites as well as sparsely fossiliferous hemipelagic mud, sampling of foraminifera was exclusively 
concentrated where there were more abundant foraminifer layers. The intent was to obtain the best age control on the ongoing hemipelagic sedimentation rate rather than to date turbidites as isolated sedimentary events one at a time. This allowed us to avoid picking reworked mud-filled or abraded foraminifera from the Bouma D-E turbidite tail and to focus on truly hemipelagic sediments in between.

The ${ }^{14} \mathrm{C}$ ages are reported in Table 2 and Fig. 5. $46 \%$ of the dates (13 of 28) fall within the tight Late Pleistocene range of $12.8-14.5 \mathrm{ka}{ }^{14} \mathrm{C}$. These are found in the main slump facies sediments in the bottoms of the two most distal Cores 7 and 9, as well as the older biogenic ooze, below the slumped material in Core 11 (Fig. 3c, 227-241 cmbsf). Note that within the body of the main slump there are no stratigraphic trends versus age and all dates herein are admixed and all of approximately 14 ka for their raw radiocarbon ages. From hemipelagic muds above the Slipstream Slump facies sediments in Cores 7 and 9 , the ${ }^{14} \mathrm{C}$ ages are all Holocene, and they consistently decrease upwards with nearly linear trends. Older Pleistocene ages are found in headwall Cores 11 and 25, with a notable age inversion (old over young) exactly at the facies boundary in Core 11 at 227 cmbsf (Fig. 3c).

\section{Discussion}

\section{Frontal Ridge Development}

The formation of Slipstream Slump and the exceptional conditions to record the Early Holocene megathrust events as a well-constrained sequence of turbidites relies on the development of the frontal ridge and the attendant isolation of small slope basins. It is necessary to have a geological model describing the frontal ridge development, along with the subsequent slumps and turbidites to appreciate the context and strengths of this particular paleoseismic record. While this particular paleoseismic record is mainly restricted to the Holocene, it can additionally serve as a template to interpret the 
morphology and structure of other modern slope basins and older, more deformed and uplifted perched slope basins within the accretionary wedge with other intervals from Cascadia's paleoseismic record might be sampled. Trying to tease paleoseismic records out of this region means finding basins capable of collecting sediment and sources for coarse clastic debris. Submarine canyons down through the continental slope have previously been sampled and are well understood (Goldfinger et al., 2012). Restricted slope basins like that at Slipstream Slump also exist within the deformed accretionary wedge and may provide other suitable candidates, especially for extending the record further back into the Pleistocene.

The oldest ages in our data set are observed in cores from the headwall scarp. The age model for the stratigraphic development and for frontal ridge growth prior to the Slipstream Slump depends on dates obtained from the headwall Cores 11 and 25. Core 11 pierces the listric footwall slide plane of the Slipstream Slump, sampling an underlying, dense, biogenic-ooze. The sedimentation rate of these older biogenic sediments is very slow at $\sim 0.05 \mathrm{~mm} /$ year or $\sim 200$ year/cm. This is comparable to biogenic sedimentation in foraminifer-rich, diatom-poor, nutrient-limited, layered North Pacific water (Brunelle et al., 2007), like atop Murray Seamount at ODP site 887 (Barron, 1998) which has a sedimentation rate of $\sim 0.04 \mathrm{~mm} / \mathrm{yr}$. The biogenic ooze sampled in the base of Core 11 yields ages up to the LGM ages $\sim 14.4-14.5 \mathrm{ka}{ }^{14} \mathrm{C}(\sim 17 \mathrm{ka}$ calibrated $)$, with one younger date of $12.8 \mathrm{ka}{ }^{14} \mathrm{C}$. The younger date comes from a region of disturbed bedding with a sand layer wrapped around clays immediately above the underlying ooze. The position of this date marks the exposed failure plane and sloughing downslope of materials shortly after the slump formed. Above this, older Wisconsinan ages $\left(23-32 \mathrm{ka}{ }^{14} \mathrm{C}\right)$ from diamict debris blocks overlie the failure plane and the ooze with its characteristic Late Wisconsinan 14.4 and $14.5 \mathrm{ka}{ }^{14} \mathrm{C}$ ages. As the older dates and the diamict blocks came from higher up the headwall scarp, the core of this deformed frontal ridge exposes an older anticlinal core or thrust panel.

From Core 11, the dates just below the unconformity, in the green foraminifer-rich ooze, are $\sim 17 \mathrm{ka}$ calibrated. The foraminifera are well preserved and little transported below the failure plane, yet they 
are older and more mixed above this. The oldest substrates cored range from $43.1 \mathrm{ka}{ }^{14} \mathrm{C}$ in Core 11 for the ooze and $40.5 \mathrm{ka}{ }^{14} \mathrm{C}$ in Core 25 , for the uppermost reworked materials. The older foraminiferal specimens both here near the failure plane up on the ridge crest and within the slump itself are all abraded, broken, infilled with mud and apparently reworked, in addition to being lower-weight (low yield per mud weight) samples. Note that the deglacial diamicts are foraminifer-poor, having at most a few $\%$ foraminifera (fast terrigenous sedimentation from IRD), while the underlying stiff green foraminiferal ooze is essentially $>90 \%$ microfossils.

In Cores 7 and 9, the upper hemipelagic sections have sparse foraminifera ( 1 to a few $\%$ of total sediment) but they contain intact foraminifers that display a typical upwards younging progression. In Cores 7 and 9 below SS12, the materials of the main slide are dominantly reworked deglacial diamict from their clasts, sand composition, Munsell colours and physical properties. However, the age range within the slump $\left(13.1-14.3 \mathrm{ka}{ }^{14} \mathrm{C}\right)$, is comparable to the ages $\left(14.4-14.5 \mathrm{ka}{ }^{14} \mathrm{C}\right)$ near the top of the green foraminiferal ooze, below the unconformity in Core 11, (Fig. 3c; 5). In addition to whatever hemipelagic mud drape and foraminifers deposited since deglaciation that the slumped materials initially held, there are much more abundant older underlying foraminifera to be incorporated via erosion and inflation (ignition) during the downslope transport of the slump as it slid, glided and bulldozed its way downhill across a bedding-controlled dip slope and failure plane on the green ooze. This reworking of some of the older foraminifera upwards into the dominant volume of slump material which is a microfossil-poor diamict, provided the dominant foraminifera that was subsequently picked to date those horizons. The failure plane downhill to the south southwest from Core 11 is not just a stratigraphic boundary of contrasting age and lithology, but also the location of a significant physical properties contrast between weak, plastic, hydrous, draping IRD-bearing muds above and denser, stiffer and drier, foraminiferal ooze of the frontal ridge below. This reworking of the older underlying foraminifera, from the uppermost layer of ooze also explains the prevalence of Late Wisconsinan ages in deglacial diamict materials which range from $\sim 12.8 \mathrm{ka}$ to $14.5 \mathrm{ka}{ }^{14} \mathrm{C}$ in this region (Table 2). The 
abraded foraminifers dated in the slump likely derive from the top of the ooze just beneath the failure plane due to their overwhelming abundance there, in contrast to the relatively few $\sim 14$ ka foraminifers recovered from the rapidly sedimented and failed diamicts themselves.

Within the dense, glauconitic, predominantly biogenic ooze in the base of in Core 11 there were two thin lithic sands near 290 and 352 cmbsf containing distinctive magnetic susceptibility peaks against the very low background values of the ooze, much like the Holocene turbidite sands discussed below. We have much less age control on this basal portion of Core 11, but we suggest that these two turbidites may represent megathrust earthquakes substantially older than the main turbidite sequence sampled and analysed here. In Fig. 5b and in Table 2, relative to the foraminiferal-based dates in Core 11 , these sand events interpolate to about $\sim 18 \mathrm{ka}$ and $\sim 36 \mathrm{ka}$, respectively. It is much more difficult to capture or to recognize turbidites in this ooze facies as the sedimentation rates are too low and the availability of contrasting terrigenous source materials was scant in this distal continental slope and former abyssal plane setting (before the latest frontal ridge developed). This pair of turbidites nonetheless, may represent the oldest evidence for large megathrust events so far detected along Cascadia.

In the debris field of the main Slipstream Slump (Fig. 1c), the jumbled set of Late Pleistocene ages from the lower portions of Cores 7 and 9 in Fig. 5a, (13.1-14.3 $\left.\mathrm{ka}^{14} \mathrm{C}\right)$ is also coincident with the LGM ice sheet extent and its rapid decay (Clague and James, 2002). These ages are also expected for the dominant deglacial sedimentation event from the diamict deposits uphill on the continental slope (Cosma et al., 2008). The lack of order is expected for the complex, interlayered debris, clasts and graded beds of the reworked debris apron of Slipstream Slump. The Pleistocene dates mark the original ages of the foraminifera contained within, or incorporated into the diamicts as they were reworked downslope and up-section. This is similar to the later slumps onto the headwall scar observed in Core 25 (Fig. 3c), however the ages of the foraminifera there reflect the age of the somewhat older sediments from a higher thrust panel exposed at the top of the headwall cliff. None of the foraminifera within 
slumped materials yield the age of the younger, Early Holocene slump event itself as it contains or includes all these older materials.

The interpretation of the sequence of sedimentary and structural events for the development of the frontal ridge is presented in Fig. 6 a-d, while panel e is a single-channel seismic reflection profile line, taken along the Slipstream Slump core transect (Fig. 1c). The section orientation is SSW-NNE, normal to the frontal ridge. Depths are converted from two-way time using a water velocity of $1500 \mathrm{~m} / \mathrm{s}$ and the sections are shown with a 3 times vertical exaggeration. For reference, Fig. 1d is the nearest multichannel seismic reflection profile GSC-89-08-MCS, showing that the thrust controlled frontal ridge has approximately doubled the thickness of the sedimentary section above the downgoing slab. At the foot of the accretionary complex, the oldest strata samples are glauconitic biogenic oozes of the abyssal plain and incipient frontal ridge (Fig. 6a). The predominantly biogenic sedimentation rate here was slow $\sim 0.05 \mathrm{~mm} / \mathrm{yr}$. Here the oldest dated materials ( $\sim 4 \mathrm{ka}$ ) have been deposited and frontal ridge development has begun by compression and thrust faulting as the accretionary wedge grew upwards and advanced to the south southwest. In Fig. $6 \mathrm{~b}$, by $\sim 17 \mathrm{ka}$, much of the frontal ridge height has grown with approximately $300 \mathrm{~m}$ of local relief. This structural uplift significantly reduces pore pressure in the ridge crest, allowing gas (methane) to migrate up into the ridge. Deglaciation $\sim 17$ ka rapidly dumped the IRD diamicton blanket, which retarded gas throughput and effectively sealed the ridge causing a gas pore pressure build up, gas hydrate formation and the onset of methane powered diagenesis. In Fig. 6c, 10 ka, Slipstream Slump occurred also generating its own turbidite tail, our event SS12. Fig. 5d shows the thin veneer of hemipelagic muds draping the ridge foreslope and interbedded turbidites downwards onto the abyssal plain. From the seismic profile, Fig. 6e, there was also a complimentary slide into the upslope basin to the north-northeast of the frontal ridge. In this interpretation, event SS12 triggered the Slipstream Slump itself. This failure served to oversteepen the ridge crest to $35-40^{\circ}$ along both sides in 2 ridge parallel scarps (Fig. 1c). Slump materials dominantly include deglacial IRD strata, but near the headwall scarp older sections thrust up in the core of the 
frontal ridge are exposed and reworked downslope. Apparently, from the position of Core 11 at the break in slope from the headwall scarp to slide debris, the slide rode down along the dip slope of the sedimentary boundary between the IRD drape and the underlying stiff biogenic ooze. The modern morphology, and that for the majority of Holocene time, due to low sedimentation rates, is represented by Fig. 6d. Here the positions of Cores 7, 9 and 10 mark the ongoing hemipelagic and episodic turbidite record, interpreted to represent the sequence of $\sim 10 \mathrm{ka}$ and later megathrust earthquakes. Core 25 at the foot of the headwall sampled a coherent slide block of diagenetically altered IRD dislodged from the headwall scar. After $\sim 6 \mathrm{ka}$, the frontal ridge became too sediment-starved to shake down much more of a turbidite record, even though turbidites attributed to Cascadia megathrust earthquakes have been documented farther to the south by Goldfinger et al. (2012). Their coring off the foot of Barkley canyon about $40 \mathrm{~km}$ to the south of Slipstream Slump (Figure 1b) similarly only captured 2 or 3 more events since $6 \mathrm{ka}$. We interpret this not to a lack of megathrust events along northern Cascadia but rather a result of sediment starvation for the Canadian portion of the continental margin (from Juan de Fuca Strait northwards) in the highstand systems tract since 6 ka.

The combination of altered IRD and older foraminifers in Core 25, and the architecture of the ridge here, demonstrate the presence of older microfossil-bearing strata thrust up near the ridge crest. Given the spacing of the thrusts as interpreted here in the outermost accretionary wedge and the limited time span of the strata sampled, we can infer that thrusts have relatively short life spans for their deformation history. The progression is to grow the ridge and overpressure the strata below transferring slip over time until a new frontal thrust breaks out, uplifting the prior thrust stack, deactivating it and eventually forming a new frontal ridge. With the time span since the last interglacial, it would seem that each thrust is used several times, over a few thousand years before it is carried up on the back of a new thrust. This southwesterly progressive movement of the deformation front, and the short lived growth of successive frontal ridges serves to form isolated slope basins in the lee of the frontal ridge. 
Each of these slope basin settings in turn preserves a high resolution, but short lived succession of deposits related to Cascadia's great earthquakes.

\section{Holocene and Postglacial Turbidite Age Model}

The rest of this paper concerns the age model and implications of the Holocene and postglacial $(<17$ ka calibrated) portions of the distal two cores, 9 and 7 (Fig.s 4 and 5). All of the chronology is based on radiocarbon dates, turbidite correlations, and the age of the seabed. It would have been more satisfying if the 1700 megathrust event were present but the records at Slipstream Slump and Barkley Canyon are both sediment starved after $6 \mathrm{ka}$. While we looked for the Mazama Ash (and other tephras) at Slipstream Slump, the site is apparently too far northwest for its range ( $>750 \mathrm{~km}$ away) and its closest occurrences are $\sim 2 \mathrm{~cm}$ thick at Mount Baker (Easterbrook et al., 2001; D. Tucker pers comm., 2015), $\sim 1 \mathrm{~cm}$ thick in the varved silts of Saanich Inlet (Blais-Stevens et al., 2011) and $\sim 2 \mathrm{~mm}$ in Effingham Inlet (Enkin et al., 2013). The Mazama ash was also not encountered at Barkley Canyon (Goldfinger et al., 2012). While individual glass shards were detected in smear slides from the underlying Pleistocene section, at Slipstream Slump, no ash layers were present in the Holocene Turbidite section. This is not surprising as the prevailing winds are onshore and most of the arc volcanoes are $200 \mathrm{~km}$ or more to the East and there activity is sporadic.

In Fig. 4 the ${ }^{14} \mathrm{C}$ ages are uncalibrated, and the positions mark actual core depths. This figure portrays the proximal to distal variation in the Slipstream Slump turbidite record, its approximate age and its correlation with other published paleoseismic records at Barkley Canyon (Goldfinger et al., 2012) and at Effingham Inlet (Enkin et al., 2013). For direct comparison we present the uncalibrated planktonic ages (Goldfinger et al., 2012) rather than their final processed age model. No dates based on benthic foraminifera were used, as the radiocarbon reservoir is too uncertain. As the radiocarbon materials used at Effingham were terrestrial, there is no need for a marine reservoir correction. On Fig. 
4, the difference in thickness down to event SS12 in the 3 Slipstream Slump cores can easily be seen to depend on the variable sand contribution between cores while the total hemipelagic section (white space) is similar. Figure 5 presents uncalibrated ${ }^{14} \mathrm{C}$ ages versus actual core depth and includes the entire depth range to show the unvarying and somewhat disordered ages (13.1 to $14.3 \mathrm{ka}$ ) throughout the underlying slump and their clear contrast to the uniform younging for the overlying sections. Figures $5 \mathrm{a}$ and $5 \mathrm{~b}$ are identical except for the limits of the horizontal age axis, wherein Fig. 5a zooms in on the post-glacial period while Fig. $5 \mathrm{~b}$ includes the total span of ages encountered. Together Fig.s 5a and $5 \mathrm{~b}$ clearly show the contrasts in age for the 3 successions: the older ridge materials, the Late Pleistocene-Early Holocene Slump and the post slump turbidite bearing section.

Both of cores 9 and 7 sedimentologically match their trigger cores within $\pm 2 \mathrm{~cm}$ and both captured the olive soupy weathered material at the seabed suggesting full core recovery and no core loss at the seabed. These cores are physically close together $(\sim 1 \mathrm{~km}$ apart $)$ atop the fan of the initial Slipstream Slump in a purely depositional setting. There is no bathymetric evidence for any channels or seabed erosion and this observation controlled the core site selection. The uppermost hemipelagic section is $\sim 4$ $\mathrm{cm}$ thicker in core 9 than in core 7 . Figure 5a shows cores 9 and 7 on a common depth scale. Dating was done only on the best foraminifera rich intervals in the upper hemipelagic sections to build sedimentation models rather than to try and date specific events or the seabed itself. The ages from each core are plotted as points and the error bars for depth and age would fit within the plotted circles. Both cores show apparent linear age progressions on Fig. 5a and the linear regression fits shown have $\mathrm{r}^{2}$ values of 0.992 (Core 7) and 0.998 (Core 9). The top of turbidite SS12 (Fig.s 4 and 5) occurs at 426 cmbsf in Core 7, and at $318 \mathrm{cmbsf}$ in Core 9. Despite the quasi-constant sedimentation rates for each of these two cores, note that their age models are clearly distinct. Taken individually, the topmost (seabed) ages apparently differ by 700 years (much greater than the $4 \mathrm{~cm}$ thickness difference above SS1). The ages of the SS12 basal turbidite and underlying debris of the original Slipstream Slump apparently differ by 1500 years, and the bulk deposition rates apparently differ by $25 \%$. It would be 
possible to produce an age model for each core individually, but they cannot both be correct and that approach would neglect the common age constraints provided by the sedimentary observations and the ready correlations for the 2 nearby turbidite successions. These 2 cores are both on the abyssal plain and too close together geographically $(\sim 1 \mathrm{~km}$, Fig. 1c) to have such substantially different depositional histories.

\section{Combined Slipstream Slump Age Model}

Using the correlations between cores 9 and 7 (Fig. 4), we can combine the ages to form a joint age model. With the understanding that the turbidite sedimentation events represent negligible durations of time, their thicknesses are removed to produce an Event-Free Depth (EFD) (Bronk-Ramsey et al., 2012; Enkin et al., 2013), representing only the thickness and deposition of the hemipelagic sediments (Tables 2 and 3). We correlated the depths of dated samples from Core 9 to the equivalent depth on the EFD scale for core 7.

All dating was done on planktonic foraminifera which grow within the upper $200 \mathrm{~m}$ of the ocean, forming their shells from carbon that is a mixture of atmospheric carbon of the day and somewhat older carbon from the top of the northeast Pacific Ocean. The Marine13 radiocarbon calibration curve (Reimer et al., 2013) includes a global average marine reservoir age of 400 years, while any regional variations are treated with a correction term $\Delta \mathrm{R}$. The marine reservoir age typically used for radiocarbon dating of marine carbonate material from the northeastern Pacific, derived from measurements of pre-bomb shells in museum collections and older shell-plant pairs on the coast, is around $\mathrm{R}=800, \Delta \mathrm{R}=400 \pm 50$ years (Robinson and Thompson, 1981; Hutchinson et al., 2004, Hughen et al., 2004). Different oceanic environments lead to distinct reservoir corrections, and for the following analysis we allow $\Delta \mathrm{R}$ to be a free variable. Variation in $\Delta \mathrm{R}$ produces an age shift, while the shape of 
the resulting age model is mostly invariant to the value of $\Delta \mathrm{R}$. An important note here is that the determination of the earthquake recurrence rate is not strongly affected by the choice of $\Delta \mathrm{R}$.

An additional age constraint is derived from the age of the seabed at the top of the core, collected in 2008 AD. Two effects add uncertainty to the effective age of the top of the core. If soft unconsolidated sediments at the top of the core were lost during the rapid insertion of core, the top several $\mathrm{cm}$ could have been lost leading to the top of the core marking an age in the past. On the other hand, the apparent sedimentation rate includes compaction which is less complete at the top of the core. This effect leads to the apparent age of the top of the core being in the future. Both the piston core and matching trigger cores were cut and described and found to have similar oxidized soupy olive mud at tops, ensuring little or no loss of the seabed. Linear extrapolations of the top measured sulfate concentrations (Fig. 2b) to the depth at which they reach sea-water concentration shows that at most 20 $\mathrm{cm}$ of sediments are lost during coring. In future studies it would be desirable to have dates closer to the seabed and other complimentary analyses such as ${ }^{210} \mathrm{~Pb}$ model ages to ensure modern $(<200$ year old) material is present. There is no recognizable increase in magnetic susceptibility or density along the core, so differential compaction effects in cores 7 and 9 are likely negligible. Nonetheless, to err on the side of caution, we estimate the prior likelihood distribution for the age of the top of the core to be a normal distribution with mean $2008 \mathrm{AD}$ and standard deviation 200 years, equivalent to $95 \%$ probability that less than $\sim 10 \mathrm{~cm}$ were lost or less than $\sim 20 \mathrm{~cm}$ was less-compacted by a factor of 2 .

We use Bayesian analysis to construct age models using the Oxcal software package (BronkRamsey, 2008). The program accepts information on the ages and depths known through the cores, called the prior information, and determines age likelihood curves for all depths, called the posterior information. Figure $7 \mathrm{a}$ and Table 3 present the calibrated joint age model for the 9 Holocene ${ }^{14} \mathrm{C}$ dates from Slipstream Slump cores 7 and 9 placed on the core 7 EFD scale. Using the events as tie points, the relative depth of the dates in the hemipelagic section between events in core 9 is transferred to the equivalent position in core 7 . The calibrated and modelled dates are represented as their likelihood 
functions. Note how the ages from the two cores now fall on the same quasi-linear trend with no apparent outliers. The common age model validates: 1) the correlations of the turbidites (dashed lines) between the 2 cores; 2 ) the continuous deposition and quasi-uniform rate of the hemipelagic sedimentation in this region; 3) the consequent Event-Free Depth model; and 4) that the selected foraminifera subsamples for ${ }^{14} \mathrm{C}$ dating originated exclusively from hemipelagic sediments rather than older material worked downslope and dropped in with the turbidite tails.

The continental shelf is broad and has had a consistent bathymetry and a stable coastline during the last several thousand years. There are neither significant river systems nor large estuaries to provide new clastic sediment. The shelf is a coarse grained sedimentary lag, is mainly reworked in periodic large storms and the shelf edge is distal to Slipstream Slump ( 40 km NE). The intervening accretionary wedge is rugged, deformed and eroded into separate ridges, terraces, channels and slope basins to catch any tractive sediment, thus, the offshore hemipelagic sedimentation rate is expected to be fairly constant. Realistic variations in sedimentation rate are taken into account in the age model using a Poisson process for sedimentation, which is included in the OxCal software. The uniformity of deposition rate is controlled by the parameter $k$ which refers to the number of independent deposition steps per unit depth, with higher values providing more uniform deposition rates.

We follow the method introduced by Enkin et al. (2013) to select the most realistic $k$-value. A set of age models are developed by OxCal with a $k$-values spanning two orders of magnitude ( 0.1 to 10 events/cm). The age model evolves from unrealistically "loose" to unrealistically "tight" values as $k$ increases from too low (superposition only, no constraint on deposition rate) to too high (uniform deposition rate), with a cusp in the following three indicators all apparent at the optimal value of $k$. The indicators are 1) the number of apparent outliers (i.e., agreement index $<60 \%$ ); 2) the mean confidence interval width; and 3) the mean normalized age deviations (i.e., the individual age determination minus the age model divided by the confidence interval). The principal is that $k$ is set as 
high as possible without over-constraining the deposition model beyond what is compatible with the geology.

For the data from Slipstream Slump alone, the optimal $k$ is between 1 and $2 \mathrm{~cm}^{-1}$, meaning that variations in deposition rate occur on average about every 0.5 to $1 \mathrm{~cm}$, or approximately 10 to 20 years. This value of $k$ in our model might possibly suggest control by large-scale ocean current variations such as the El Niño cycle and the Pacific Decadal Oscillation but much additional detailed coring and dating work would be required to investigate this and to relate it to specific physical oceanographic causes. Interpolated posterior ages are almost unaffected by the specific $k$ value chosen, however the confidence interval for extrapolated ages increases rapidly as $k$ decreases. Given the additional age control from the Barkley Canyon cores and the correlation to Effingham Inlet (Fig. 4) the need to extrapolate is removed and the sensitivity to the exact $k$-value is less significant than for the model presented in Fig. 7a alone.

The average hemipelagic sedimentation rate for the interval from 9-2 ka is $0.21 \mathrm{~mm} /$ year. For comparison, the Cascadia Subduction Zone hemipelagic sedimentation rates determined by Goldfinger et al. (2012, Appendix 1, Sedimentation Rate worksheets Column C) range from 0.025 to $0.65 \mathrm{~mm} /$ year with a median of $0.14 \mathrm{~mm} /$ year. Sedimentation rates from Ocean Drilling Program (ODP) Leg 168, which includes coring more distally on the abyssal plain from $\sim 190-240 \mathrm{~km}$ offshore of Vancouver Island, range from $\sim 0.12-0.49 \mathrm{~mm} /$ year ( $\mathrm{Su}$ et al., 2000). Core MD02-2496, $30 \mathrm{~km}$ up the continental slope from the Slipstream Slump, has a postglacial hemipelagic sedimentation rate of $0.48 \mathrm{~mm} /$ year (Cosma et al., 2008). Part of this rate reflects tractive load off the shelf which is absent at Slipstream Slump due to channel interception or to deposition in intervening slope basins on the upslope side of the frontal ridge.

\section{Combined Slipstream Slump - Barkley Canyon Age Model}


The inferred ages of the turbidites using only the data from Slipstream Slump are listed in the “Slipstream 95\% CI" columns in Table 4 (where CI stands for Confidence Interval). They have similar ages to those observed for two stations off the mouth Barkley Canyon (M9907-08 and M9907-09, Goldfinger et al., 2012), collected about $40 \mathrm{~km}$ south of the Slipstream Slump (Fig. 1b). Since deglaciation, Barkley Canyon and the continental slope southwest of Vancouver Island as a whole, has had no sediment source (Clague and James, 2002; Cosma et al., 2008) except storm events on the 80 $\mathrm{km}$ wide lag continental shelf and failures along the canyon system upslope from the shelf edge to the frontal ridge (Patton et al., 2013, Fig. 1). There is no sediment delivery system from small youthful streams on the west coast of Vancouver Island and most of the seabed, including Barkley Sound has little modern sediment accumulation. Barkley Canyon itself is a lag feature from Wisconsinan and deglacial times prior to 14 ka radiocarbon years. From unpublished turbidity data near the Neptune node at top of the canyon $\left(48^{\circ} 19^{\prime} \mathrm{N}, 126^{\circ} 03^{\prime} \mathrm{W}\right)$ there is significant suspended hemipelagic material (G. Lintern, pers. comm., 2014). The surveying performed by (Goldfinger et al., 2012) notes an active fault and small basin behind the frontal ridge. With this as a trap for fines, the cores taken off the canyon mouth consist primarily of turbidite layers with little intervening hemipelagic muds. This is probably the main reason for the lower hemipelagic sedimentation rate at the Barkley Canyon site M9907-09PC compared to Slipstream Slump core 7 and 9 (Fig. 4). As a canyon mouth setting, Barkley is typical in having sufficient current velocity to either not deposit as much hemipelagic mud between events, or to erode some as the next turbidite event comes through.

In Fig. 4 we compare and correlate the Barkley Canyon reference core, M9907-09PC, with the Slipstream Slump cores, noting that the other Barkley Canyon trigger cores and piston cores fully complement and support these correlations. For the purpose of distinguishing the turbidite horizons from the 3 sites on our Fig. 4 we used SS for Slipstream Slump, B for Barkley Canyon (originally T in Goldfinger et al., 2012) and E for Effingham Inlet (Enkin et al., 2013). The assumption from the broader regionally correlated events in Goldfinger et al. (2012) is that Cascadia-wide earthquake 
shaking locally triggers the release of quantities of coarse-grained sediments which depend on the intensity and duration of shaking or tsunami effects, remobilizing shelf and estuarine sediments. Goldfinger et al. (2012) present examples which demonstrate that density and magnetic susceptibility provide excellent proxy measurements between different depositional systems for these coarse-grained sediments in several locations along the Cascadia margin. Here we attempt a more modest and geographically restricted correlation along only $40 \mathrm{~km}$ of the northern Cascadia Margin. The physical properties not only distinguish the turbidites from the hemipelagic sediments, but they also reveal details about the size and character of the individual turbidites that we employ to correlate horizons from separate cores. Notably in grain size and magnetic character, the sands layers of the initial Slipstream Slump are distinctively bimodal in grain size and more magnetite rich than the subsequent Holocene turbidites shaken off the oversteepened ridge crest and slide scarp.

There are several suggestive ties based on sedimentary observations and the character of the magnetic susceptibility profiles (Fig. 4). As noted by Goldfinger et al. (2012), B11 is distinctive for its rapid onset, high magnetic susceptibility amplitude and long profile that is easily correlated across all Barkley Canyon cores. We correlate B11 to the SS3 turbidite atop Slipstream Slump. The largest magnetic susceptibility amplitude turbidites are B20 (Barkley Canyon) and SS12 (Slipstream Slump). Above B11 and SS3, we see B9 and SS2 have a similar multipeak low amplitude shape, while B6 and SS1 both show a relatively high amplitude rapid onset susceptibility signal. B5 is better imaged in the Barkley Canyon trigger cores than the piston cores, but the only possible correlative layer across the Slipstream Slump cores is in the undated Core 10 (Fig. 4). Between B11-SS3 and B20-SS12, there are 9 turbidites identified from Barkley Canyon, but 8 in Slipstream Slump. B12 and B13 are subdued, as are SS4 and SS5. B16 and SS8 are both notable for having clearly observable basal sand layers. The best correlation is a one-to one correspondence from B11-SS3 down to B18-SS11, and then correlating both B19 and B20 to what was recognized as a single turbidite complex SS12 at Slipstream Slump. 
We now place the Barkley Canyon radiocarbon samples on the Event-Free Depth scale from core 7 at Slipstream Slump as we previously did with those from core 9 to build the composite Slipstream Slump model. In order to make a coherent analysis, we systematically apply the following rules. First, only dates made on planktonic foraminiferal samples are used. While there is uncertainty concerning the marine reservoir correction for dates from a single marine setting, the difficulties are confounded by accepting dates affected by independent carbon reservoirs as sampled by benthic foraminifera.

Furthermore, benthic foraminifera are susceptible to reworking old carbon as they are agglutinated sand grains which can include old planktonic foraminifera. An additional reason is that there is no independently determined reservoir correction for benthic foraminifers. Second, we apply a single constant marine reservoir correction to all samples. There may, in fact, be a change in marine reservoir over time due to changing ocean currents, but they would always be equivalent at two sites with similar depths only $40 \mathrm{~km}$ apart about $100 \mathrm{~km}$ offshore.

We accept and apply the same depth corrections (half the sample depth interval plus the depth below base of turbidite, and the erosion estimates) as stated in Appendix 1 of Goldfinger et al. (2012) as we incorporated his turbidite depths and dates. The depths are scaled and corrected for the two different apparent hemipelagic sedimentation rates by multiplying by the Slipstream Slump hemipelagic sedimentation rate $(21 \mathrm{~cm} / \mathrm{ky})$ and dividing by that of Barkley Canyon $(8.6 \mathrm{~cm} / \mathrm{ky}$, Goldfinger et al., 2012, their Fig. 9a). For depth corrections that would place the sample below the underlying turbidite, they were set to one centimeter above, thus ensuring that the radiocarbon ages fall between successive turbidites. Note that the depth corrections usually place the Barkley Canyon radiocarbon samples and their age assignments closer to the underlying than to the overlying turbidite. This is not unreasonable, as the samples are seen to come from a depth range which is very close to if not including the top limit of the underlying turbidite and in fact they state that they could not always distinguish between Bouma D and E facies muds (Goldfinger et al., 2012, Fig. 17). Thus it is reasonable that dates from a 
turbidite's D facies tail in fact record the hemipelagic material available in the canyon at the time the turbidite occurred.

Figures $7 \mathrm{~b}$ and $\mathrm{c}$ illustrate the resulting combined Barkley Canyon - Slipstream Slump age model (Table 3). Fig. $7 \mathrm{~b}$ uses $\Delta \mathrm{R}=0 \pm 50$, while Fig $7 \mathrm{c}$ uses the marine reservoir used by Goldfinger et al. (2012) for planktonic foraminifera, $\Delta \mathrm{R}=420 \pm 84$. There are 5 radiocarbon dates which do not lie on a simple quasi-linear age model (indicated with upside-down likelihood distributions in Fig. 7). The lower two outliers (09PC-CASC235 and 09PC-CASC242) were also recognized by Goldfinger et al. (2012). The current analysis suggests that the top three dates (08TC-CASC191, 09PC-CASC236, and 08TC-CASC1) are also anomalously old and are incompatible with any simple sequential sedimentary model. Such outliers are indicative of reworked sediments and contamination by carbon from older forams, which are endemic to turbidite settings especially those sourced along long-system submarine canyons of Cascadia.

All other radiocarbon dates from the two studies fall on a simple sequential age model, thus justifying the turbidite correlations and event-free depth decisions. The only difference between these two age models (Figs. 7b and c) is that the larger marine reservoir in Fig. 7c translates the age model about 400 years younger. Even allowing for an increase in deposition rate at the top (or undercompaction) through the Poisson-process model, the posterior age distribution inferred for the top of the core is far in the future $(2364 \mathrm{AD} \pm 314 \mathrm{yr}$ at $95 \%$ confidence interval) when the marine reservoir is set to the conventionally used value of $\Delta \mathrm{R}=420 \pm 84$ (Fig. 7c). We prefer to use a different $\Delta \mathrm{R}$ value as it provides the best fit to our data using OxCal's capabilities as discussed more fully below. To fully resolve this reservoir issue requires recoring to obtain shallower dates, other long core high resolution dating studies and other techniques such as measuring the upper water column ${ }^{14} \mathrm{C}$ reservoir in this region. We acknowledge that requiring a different $\Delta \mathrm{R}$ value requires reassessment of other dates and correlations that is beyond the scope of this study. 


\section{Correlation with Effingham Inlet Seismite Chronology}

The successful combination of the Slipstream Slump and Barkley Canyon age constraints into a coherent age model confirms the correlations of the turbidite events based on their sedimentary and physical properties, and provides a much more complete age model with Slipstream Slump data dominating the last 4000 years and Barkley Canyon providing all the data before $7000 \mathrm{BP}$. The age model of sedimentation of the Inner Basin Effingham Inlet (150 km NE of the Slipstream Slump and Barkley Canyon sites, Fig. 1a) is based on 68 radiocarbon dates from terrestrial plant material (atmospheric reservoir only, requiring no marine reservoir correction) and the well-dated Mazama Ash, along with sedimentation rates constrained by annual lamination counts (Enkin et al., 2013). Twentyone mass-wasting deposits are recognized in Effingham Inlet. While it is not possible to make a oneto-one correlation between all of the events recorded at Effingham Inlet to those recorded at Slipstream Slump and Barkley Canyon, a reasonable correlation is possible if we limit the search to the largest deposits in Effingham Inlet which display a thickness of at least $10 \mathrm{~cm}$ (indicated as "E" intervals with black outlines on Fig. 4). Because the magnetic susceptibility profiles of these appear quite distinct from those seen off the coast, the correlations are based on age with guidance from the relative amplitudes of the susceptibility profiles.

The ages of the Effingham Inlet event correlations marked on Fig. 4 are all perfectly compatible with the Slipstream-Barkley Canyon age model with $\Delta \mathrm{R}=0 \pm 50$ years (Fig. $7 \mathrm{~b}$ ). The green or light-gray curve on Fig. 7d displays the combined age model from Slipstream Slump, Barkley Canyon and Effingham Inlet, which is always contained within the blue or dark-gray $95 \%$ confidence interval of the Slipstream-Barkley Canyon age model. Furthermore, the combined age model fits the age constraint for the top of the core. On the other hand, there are significant incompatibilities with the $\Delta \mathrm{R}=420 \pm 84$ years age model (Fig. 7c, and medium-gray curve on Fig. 7d). While the E4 age is near the B6-SS1 age, the E6 and E8 events do not coincide to the turbidites on that age model. E12 could date B12-SS4 
rather than B11-SS3, and E20 could date B21 rather than the B19+B20-SS12 event, but these correlations would mean that large events in Effingham coincide to minor events at Slipstream Slump and Barkley Canyon (as indicated by the sedimentology and physical properties) while major events in those deep offshore sites have no correlative events in the Effingham Inlet record. Keep in mind that Effingham Inlet (Fig. 1) lies directly inboard from the subduction zone edge sites at Slipstream Slump and Barkley Canyon. Hence megathrust earthquakes here are all likely to have a common spacing in time and physical signature in the sediments along this short segment of the subduction zone. While the sediment sources and transport processes differ among these three sites, the things they share in common are that there is ongoing sedimentation, sand sources are available, and the only common trigger they could experience is a megathrust earthquake.

\section{Sedimentological issues with the age model}

While a ${ }^{14} \mathrm{C}$ marine reservoir of $\Delta \mathrm{R} \approx 400$ years is usually applied for calibrating radiocarbon samples collected from the Northeast Pacific, we propose a younger reservoir mostly because of the age of the top of the core and supported by the correlation with the Effingham Inlet ages. The anomalously young reservoir correction is certainly not the result of the top of the sediment cores being lost. Every centimeter lost results in the inferred age of coring being 15 more years into the future, the opposite direction of the anomaly which needs to be addressed.

More subtle is the effect of erosion of the hemipelagic sediments by the turbidity currents. At Barkley Canyon, an erosion correction of $2 \mathrm{~cm}$ is only applied to turbidite B6 (Goldfinger et al., 2012, Appendix 1). Throughout the study, no basal erosion correction is made on most turbidites dates, and the corrections are usually less than $3 \mathrm{~cm}$. Comparing the grain size of the sands, their thicknesses and magnetic susceptibilities, the Slipstream Slump turbidites are finer grained, muddier, thinner and roughly about half the magnetic susceptibility of those at Barkley Canyon (Fig. 4). The Slipstream 
Slump turbidites are distal and low energy as indicated by their flat bases and fine-grained nature (muddy sands and silts), and the thick intervening hemipelagic mud sections have well-preserved sedimentary structures including discrete foraminifera rich bands. Hemipelagic accumulation in our cores at the toe of Slipstream Slump is twice that at Barkley Canyon (Fig. 4) so while we do not rule out erosion or missing section, there should be proportionately less loss at Slipstream Slump. In modelling the ${ }^{14} \mathrm{C}$ ages with $\Delta R=420 \pm 84$ years, we tested the sensitivity of the inferred age of the top of the core to different amounts of basal erosion below the turbidite layers in two ways. We used Oxcal to produce age models with 1,2 and $5 \mathrm{~cm}$ of erosion below each turbidite, and by adding 2, 4, and $10 \mathrm{~cm}$ of extra hemipelagic sediments below the largest turbidite, SS3. The inferred age of the top of the core does indeed get closer to the present when extra sediment is assumed to have been eroded. However we find that the top age youngs by 33 years per $\mathrm{cm}$ of basal turbidite erosion, with the implication that $10 \mathrm{~cm}$ must be missing under each turbidite to bring the best estimate of the core top to $2008 \mathrm{AD}$, or 5 $\mathrm{cm}$ to bring down to one standard deviation in the future, 2008+160 AD. This is clearly excessive and unreasonable for this distal low-energy setting as thinner, finer grained turbidites at Slipstream Slump would need to be more erosive than their correlative layers at Barkley Canyon. Even less possible is the amount of erosion necessary to bring the top of the core to a realistic age were SS3 to be the only erosive turbidity current. With that scenario, there would have been $93 \mathrm{~cm}$ of erosion below SS3 to bring the top to $2008 \mathrm{AD}$, or $48 \mathrm{~cm}$ for $2008+160$ AD. These age modelling experiments suggest that the regional ${ }^{14} \mathrm{C}$ marine reservoir determined from coastal bivalves is not applicable to the plankton species and offshore environment we sampled.

As a check for the optimal marine reservoir, we ran OxCal on the combined Slipstream SlumpBarkley Canyon-Effingham Inlet-core-top age model, but giving $\Delta \mathrm{R}$ a uniform prior distribution, with equal probability between -400 and 400 years. The resulting $\Delta \mathrm{R}$ is $-25 \pm 29$ years $(95 \%$ confidence interval), insignificantly different from $\Delta \mathrm{R}=0$ years we present in Fig. 6b. Using these age constraints and these correlations, no other marine reservoir value leads to a high-agreement age model. 
The global ocean circulation model of Butzin et al. (2005, their Fig. 3a) suggests an oceanic surface reservoir age of 300 years $(\Delta \mathrm{R}=-100)$ for the region off Vancouver Island. The ocean waters $<200 \mathrm{~m}$ depth in this part of the Pacific in Holocene time are younger, with respect to their radiocarbon content, than the sediment substrates for clams used to calibrate the shell-wood pairs in the shallow coastal environment with their component of reworked carbon from the land and older sediment substrates that characterize the clams' habitat. Our $\Delta \mathrm{R}$ interpretation suggests that surface waters in this region have limited contact with the relatively ${ }^{14} \mathrm{C}$-depleted (older) deep waters below and that that the modern surface waters resemble the sub-tropical Pacific gyre rather than the northern Pacific gyre, as is conventionally assumed and used to correct single foraminiferal ages. Throughout our samples, $N$. pachyderma (sinistral) is more abundant than N. pachyderma (dextral), with a sinistral:dextral ratio of $\sim 2: 1$, regardless of sample depth or size fraction picked, the same as the current living population in this region, thus our samples indicate a mixing between polar and sub-polar waters and species. Despite the intentional sampling of the most carbonate rich intervals in the hemipelagic sediments, the samples taken do not represent single seasonal plankton blooms with their own unique conditions. Given the intervals sampled $(2 \mathrm{~cm})$ and the low sedimentation rates in this region, it is important to note that these ${ }^{14} \mathrm{C}$ foraminiferal data represent long-term (multiple decades) average upper water column conditions.

\section{Age model summary}

The following assumptions and methods were used to create the age model which dates turbidites observed below the continental slope of Vancouver Island. There are two classes of sedimentation in the studied settings: rapidly deposited sediments from bottom tractive turbidites or other mass-wasting events and quasi-continuous hemipelagic sedimentary deposition ultimately originating from the uppermost water column. They can be distinguished through sedimentological and physical property 
logging. The rapidly deposited thicknesses of coarser materials are removed from the age model to produce an "Event-Free Depth" of quasi-continuous deposition.

The mass-wasting events are assumed to have shared wide-spread synchronous triggers. In the region under study, the trigger is understood to be large subduction-related earthquakes which cause significant accelerations and prolonged cycles of ground-shaking that affect pore pressure, sediment strength and slope stability (Morgenstern, 1967). Subduction-related earthquakes provide the only reasonable trigger for the turbidite events sourced from the frontal ridge at Slipstream Slump (even if part of the set up for the initial slumping was gas hydrate destabilization, as suggested by Spence et al.; 2000), and they are likely causes in the other nearby correlated regions. The BSR for the frontal ridge at Slipstream Slump is $200 \mathrm{~m}$ into the subsurface from seismic sections (Riedel et al., 2006; Haacke et al., 2008; Lopez et al., 2010) so it is highly unlikely that ongoing gas hydrate destabilization is a direct cause of slumping or turbidites at Slipstream Slump.

Sedimentological and physical property characteristics are influenced by the size and character of the trigger. Despite significant differences in the sediment sources regions and transport mechanics, some of the sand correlations among the sites are very strong and a one-to-one correlation of the weaker events provide little room for alternate correlations between Slipstream Slump and Barkley Canyon (Fig. 7b). In the final analysis, the sedimentological correlation is between Slipstream Slump and Barkley Canyon with additional age control and confirmation provided by the thicker $(>10 \mathrm{~cm})$ deposits observed in Effingham Inlet (Fig. 7d).

Age constraints from separate cores are combined on a common event-free depth scale based on Slipstream Slump Core 7 by preserving the relative intervals between the correlated turbidite horizons. As well as radiocarbon ages and constraints from sediments, we include the age of the seabed at the top of the core. Using a Poisson-process deposition model, a combined age-model is produced. There are two free variables, the marine reservoir age and the Poisson-process $k$-value. As with any age model, outliers are expected but they must be recognized and they must have physically realistic explanations. 
Necessary, but not sufficient, conditions to accept the resulting age model is that the age constraints must agree (as defined by Bronk-Ramsey, 2008) and the geological and oceanographic implications must be physically realistic. The model is falsifiable, but is not provable. The model's ultimate acceptability derives from its utility to make testable predictions. We cannot provide definitive mechanisms which justify the synchroneity of turbidite deposits and how their sedimentological characteristics depend on the degree of shaking (although Goldfinger and colleagues are working on flume experiments to this end, 2012). Nevertheless, such mechanisms apparently do exist, since we have discovered a coherent regional paleoseismic record.

\section{Turbidite Ages}

Our preferred age model is based on a combination of data from Slipstream Slump and Barkley Canyon, with tuning of the marine reservoir based on the age of the top of the core and the ages of the large event deposits from Effingham Inlet. The estimated ages of the turbidites are listed in Table 4. The initial slump at Slipstream Slump (SS12, Fig. 7b) occurred at $10.8 \pm 0.2$ ka calibrated BP and produced a steep scarp from which subsequent turbidite sediments were sourced. This initial Slipstream Slump and its SS12 tail were followed by 9 more turbidites over the next 4.2 thousand years (Table 4). After the major turbidite at $6.6 \mathrm{ka}$ (SS3), only two more turbidites were observed at shallower levels. SS3 was a large event, both for its relative thickness and the amplitude of its magnetic susceptibility anomaly (Fig. 4). Both Barkley Canyon and Slipstream Slump sit north of the southernmost margin of the Pleistocene ice sheets, which provided thick sedimentary sources that have not been renewed since deglaciation around $17 \mathrm{ka}$ cal. $\mathrm{BP}\left(14 \mathrm{ka}{ }^{14} \mathrm{C}\right.$, Table 2$)$. We hypothesize that the local sedimentary systems in both sites became sediment-starved after the shaking which released the SS3 and B11 turbidites. In part this is due to the establishment of modern sea level circa 6000 years ago and the waning of transgressive downslope reworking with the transition to the modern highstand system tract. 
In Fig. 8, the independently determined ages of turbidites from several regions within $300 \mathrm{~km}$ distance of Slipstream Slump are plotted with a set of possible correlations. The coastal estuarine record from the submerged coastlines in Washington State (Atwater et al., 2004) and the varved Saanich Inlet record (Blais-Stevens et al., 2011) are limited to the last $\sim 4,000$ years. Turbidite channel sites in Juan de Fuca and Cascadia canyons are given as published (Goldfinger et al., 2012, Fig. 52 and Appendix 1), while results from Barkley Canyon dates have been combined and recalculated along with those from Slipstream Slump. The proposed correlations on Fig. 8 display differences in ages, some apparently significant. Note that the seismites have been dated using different strategies (event dating versus ongoing sedimentation modelling) and a unified treatment is necessary to test the hypothesis that they were the results of widespread synchronous triggering by megathrust earthquakes as opposed to separate events.

The key value needed to assess earthquake hazard along Cascadia is the recurrence time and distribution of shaking from megathrust earthquakes for any particular length of coastline. Between SS12 and SS3, it is likely that all major shaking events were recorded by the Slipstream Slump location. The directions and rates of plate motions are not likely to have varied between $10 \mathrm{ka}$ and $6 \mathrm{ka}$ due to the long visco-elastic relaxation times governing lithospheric stress in these systems. Since the strain rate due to subduction of the Juan de Fuca plate is approximately constant as judged from the magnetic stripes or hotspot tracks on the longer term (half million years; Gripp and Gordon, 1990) or the consistency of the geodetic deformation in the shorter term on a decade scale (Mazzotti et al., 2011), the recurrence rate in the early Holocene is expected to be similar to today. The great advantage of using the Slipstream Slump chronology over the chronologies of Effingham and Saanich Inlets on adjacent Vancouver Island is that it resides directly on the leading edge of the subduction zone and is sensitive to megathrust earthquakes and likely unaffected by local crustal events or unrelated subaerial geological processes. Judging from the current seismicity pattern and the inherent weak rheology of this thin, modern frontal ridge at the outermost edge of the accretionary wedge, there can be no 
significant shaking derived from nearby local crustal earthquakes in the accretionary prism. Also, while large in-slab earthquakes near the deformation front may be possible, the current in-slab seismicity there is very sparse (e.g. Obana et al., 2015) and additional slumps that might be due to nearby large in-slab events are absent from the span of this paleoseismic record. Collectively this means that there are no extra megathrust earthquakes, beyond the widely correlated ones, to increase the seismic hazard at the northern end of the Cascadia subduction zone. Because Slipstream Slump is very close to the seismic rupture plane, it is very likely to have recorded all of the megathrust events while it had sufficient sediment supply. The 9 inter-earthquake intervals from SS12 to SS3 have a mean recurrence rate (determined using the OxCal "difference" command) of $460 \pm 140$ years $(1 \sigma)$ and a range of 278 to 745 years (Table 4$)$.

\section{Conclusion}

Slump features off the frontal ridge of accretionary prisms are simple sedimentary systems particularly well-suited to study subduction-related paleoseismology. The ridge itself is too thin and weak to produce substantial crustal earthquakes capable of generating local turbidites. The water depth ( $>2000 \mathrm{~m}$ ) is too great to be affected by storm, wave or tide loading. The frontal ridge setting shields the debris flow apron from other sources of tractive sediments which could be derived from farther up the continental slope and shelf caused by storms, landslides, crustal earthquakes closer to the continental margin, or tsunamis. The turbidity currents originating from the frontal ridge as triggered by subduction-related earthquakes are relatively small and local, leading to little erosion (out on the abyssal plain) of the continuously-deposited hemipelagic sediments and assisting the establishment of a useful age model.

The Slipstream Slump, $85 \mathrm{~km}$ off of Vancouver Island, Canada, provides an excellent record of Early Holocene (10.8 to $6.6 \mathrm{ka}$ cal. BP) earthquakes along the northern Cascadia Subduction Zone. The 
ridge rose to $500 \mathrm{~m}$ above the abyssal plain after its core of interglacial sediments ( $45 \mathrm{ka} \mathrm{cal}$.) was deposited. A thick blanket of IRD was deposited from the local LGM to the time of rapid ice sheet decay (17 to $15 \mathrm{ka}$ cal. BP). At $10.8 \pm 0.2 \mathrm{ka}$ cal. BP, the 3-km wide Slipstream Slump failed between two tensional normal faults perpendicular to the ridge axis. Eleven subsequent turbidites fell off the oversteepened headwall scarp, with hemipelagic sediments accumulating between the events. These turbidites were identified and correlated along a transect of 3 cores, based on sedimentological and physical properties data.

Unique one-to-one correlations are established between the Slipstream Slump turbidites and those observed at the base of Barkley Canyon (Goldfinger et al., 2012), $40 \mathrm{~km}$ to the south, based on their physical properties profiles and ages. There are problems with quantifying the ability of earthquakes to generate a turbidite record, but earthquakes are the one widespread triggering mechanism to cause simultaneous turbidite deposits along a long fault system, as discussed generally by Talling (2014). The turbidite record, even for well-correlated events, has some internal facies variation as we explained for the Slipstream Slump core transect and as discussed for the Cascadia slope canyon records by Atwater and Griggs (2012) and Atwater et al. (2014). Nonetheless, a combined age model is constructed by positioning the dates measured at Barkley Canyon at the corresponding position on the event-free depth of the Slipstream Slump cores. Only ${ }^{14} \mathrm{C}$ dates measured on planktonic foraminifera gathered from hemipelagic sediments were used. The hemipelagic deposition rate is well-modelled using Bayesian analysis and the Poisson-process sedimentation model incorporated into the program Oxcal (Bronk Ramsey, 2009).

The marine radiocarbon reservoir which correctly produces a zero age at the tops of the cores is $\mathrm{R} \approx 400$ years, $\Delta \mathrm{R} \approx 0$ years (Fig. $7 \mathrm{~b}$ ) rather than the $\mathrm{R} \approx 800$ years, $\Delta \mathrm{R} \approx 400$ years (Fig $7 \mathrm{c}$ ) typically used to correct marine coastal shell ${ }^{14} \mathrm{C}$ ages in this region (Goldfinger et al., 2012, use $\Delta \mathrm{R}=420 \pm 84$ for their Barkley Canyon analysis). The younger marine radiocarbon reservoir $(\Delta R=0 \pm 50)$ is further validated by the complete agreement of the turbidite ages determined from Slipstream Slump and Barkley with 
the ages of the larger ( $>10 \mathrm{~cm}$ thick) turbidites in Effingham Inlet (150 km away) which were based on radiocarbon dates from terrestrial plant material (requiring no reservoir correction) and the well-dated Mazama Ash (Enkin et al., 2013).

The number of Early Holocene megathrust earthquakes observed at Slipstream Slump and their interval times are similar to those found among other paleoseismic records (Goldfinger et al., 2012) for the entire length of Cascadia (Fig. 8). Since there are no extra events at Slipstream Slump, the correlation to the megathrust record farther south is clear and uncomplicated. Our study here at Slipstream Slump is a confirmation of the Goldfinger et al. (2012) model that in suitable depositional settings earthquake-generated turbidites are correlatable and datable. This record also stands as a proof of concept for seeking out other isolated slope basins for offshore paleoseismic records, in preference to the longer system canyons through the continental shelf with their more complex erosion and depositional patterns and attendant hiatuses (unconformities). The canyons through the continental slope always carry bottom currents, are more erosional, often lack predominant hemipelagic facies and necessitate the sampling of reworked turbidite tails (Bouma D and E) for most of their datable materials.

Because the Slipstream Slump experienced near-field shaking as its trigger and likely captured all megathrust earthquakes from about 10.8 ka to 6.6 ka, two important conclusions can be made. First, the megathrust earthquake ruptures identified by the study of deep sea turbidites farther south off the U.S. coast (Adams, 1990; Goldfinger et al., 2012) extend along northern Cascadia as well. This supports the contention that Cascadia mainly fails over its entire length in megathrust events greater than magnitude 9. Second, there are no additional strong shaking events during the Early Holocene period at Slipstream Slump, meaning the seismic hazard from the northern Cascadia Subduction Zone is not higher than that determined farther south. The recurrence rate for the frequent Early Holocene events is $460 \pm 140$ years $(1 \sigma)$. These conclusions are important constraints for seismic hazard calculations that form the basis for earthquake resistant design prescribed in building codes. 


\section{Acknowledgements}

We thank the officers and crew of the CCGS John P. Tully and scientific contributions from Ross Haake, Greg Middleton, Peter Neelands, Kelly Rose, Meagan Hogg, Lionel Esteban, Jeanne Percival and William Waite. Thoughtful internal reviews were provided by Joe Henton, GSC-Pacific and Jason Chaytor, WHOI. We thank 2 anonymous reviewers for BSSA for their helpful suggestions pertaining to an earlier version of this paper in 2013 and the 2 detailed reviews by Chris Goldfinger and Guillaume St. Onge pertaining to this submission and the helpful suggestions included in this final edit. Any use of trade or product names is for descriptive purposes and does not imply endorsement by the Canadian or US governments.

\section{References}

Adams, J. 1990. Paleoseismicity of the Cascadia Subduction Zone - Evidence from turbidites off the Oregon-Washington margin, Tectonics, 9: pp. 569-583.

Amorosi, A. 1995) Glaucony and sequence stratigraphy: a conceptual framework of distribution in siliciclastic sequences. Journal of Sedimentary Research, B65: pp. 419-425.

Atwater, B. F., Carson, B., Griggs, G. B., Johnson, H. P., and Salmi, M. S. 2014. Rethinking turbidite paleoseismology along the Cascadia subduction zone. Geology. Doi: 10.1130/G35902.1

Atwater, B. F., and Griggs, G. B. 2012. Deep Sea Turbidites as Guides to Holocene Earthquake History at the Cascadia Subduction Zone - Alternative Views for a Seismic-Hazard Workshop, United States Geological Survey Open File Report 2012-1043: 58 p. 
Atwater, B. F., Musumi-Rokkaku, S., Satake, K., Tsuji, Y., Ueda, K., and Yamaguchi, D. K. 2005. The orphan tsunami of 1700 - Japanese clues to a parent earthquake in North America, United States Geological Survey Professional Paper 1707: 133 p.

Blais-Stevens, A., Rogers, G. C., and Clague, J. J. 2011. A revised earthquake chronology for the last 4,000 years inferred from varve-bounded debris-flow deposits beneath an inlet near Victoria, British Columbia, Bulletin of the Seismological Society of America, 101: pp. 1-12.

Bornhold, B. D., and Giresse, P. 1984. Glauconitic sediments on the continental shelf off Vancouver Island, British Columbia, Canada. Journal of Sedimentary Petrology, 55: pp. 653-664.

Bouma, A. H., Normark, W. R., and Barnes, N. E. 1985. Submarine fans and related turbidite systems, New York, Springer-Verlag: $351 \mathrm{p}$.

Bouma, A. H. 1962. Sedimentology of some flysch deposits: A graphic approach to facies interpretation, Elsevier: 168 p.

Braunmiller, J. and Nabelek, J. 2002. Seismotectonics of the Explorer Plate, Journal of Geophysical Research, 107: pp. 2208-2233.

Bronk Ramsey, C. 2009. Bayesian analysis of radiocarbon dates, Radiocarbon, 51: pp. 337-360.

Bronk Ramsey, C., Staff, R. A., Bryant, C. L., Brock, F., Kitagawa, F., van der Plicht, J., Schlolaut, G., Marshall, M. H., Brauer, A., Lamb, H. F., Payne, R. L., Tarasov, P. E., Haraguchi, T., Gotanda, K., Yonenobu, Y., Yokoyama, Y., Tada, H. R. and Nakagawa, T. 2012. A complete terrestrial radiocarbon record for 11.2 to $52.8 \mathrm{kyr}$ B.P., Science, 338: pp. 370-74.

Chamov, N.P. and Murdmaa, I. O. 1995. Coarse fraction minerals in of sands in the Cascadia margin sediments, Scientific Results, ODP Leg 146 (Pt 1), pp. 33-43.

Clague, J. J., Bobrowsky, P. T. and Hutchinson, I. 2000. A review of geological records of large tsunamis at Vancouver Island, British Columbia; and implications for hazards, Quaternary Science Reviews, 19: pp. 849-863. 
Clague, J. J., Harper, J. R., Hebda, R. J. and Howes, D. E. 1982. Late Quaternary sea levels and crustal movements, Coastal British Columbia, Canadian Journal of Earth Sciences, 19: pp. 597-618.

Clague, J. J., and James, T. S. 2002. History and isostatic effects of the last ice sheet in southern British Columbia. Quaternary Science Reviews 21: pp. 71-87.

Cosma, T. N., Hendy, I. L. and Chang, A. S. 2008. Chronological constraints on cordilleran ice sheet glaciomarine sedimentation from core MD02-2496 off Vancouver Island (western Canada), Quaternary Science Reviews, 27: pp. 941-955.

Cousens, B. 2010. Geology and petrology of seafloor volcanic rocks of the northeastern Pacific Ocean, offshore Canada, Geoscience Canada, 37: 16 p.

Cowan, D. S., Botros, M., Johnson, H. P. 1986. Bookshelf tectonics: rotated crustal blocks within the Sovanco Fracture Zone, Geophysical Research Letters, 13: pp. 995-998.

Dallimore, A., Enkin, R. J., Pienitz, R., Southon, J., Baker, J., Wright, C., Pedersen, T., Calvert, S., Ivanochko, T. and Thompson, R. 2008. Postglacial evolution of a Pacific coastal fjord in British Columbia, Canada - interactions of sea level change, crustal response and environmental fluctuations; results from Mona Core MD02-2494, Canadian Journal of Earth Sciences, 45: pp. 1345-1362.

Darling, K. F., Kucera, M., Kroon, D. and Wade, C. M. 2006. A resolution for the coiling direction paradox in Neogloboquadrina pachyderma, Paleoceanography, 21: 2, DOI: 10.1029/2005PA001189

Davis, E. E., and Hyndman, R. D. 1989. Accretion and recent deformation of sediments along the northern Cascadia subduction zone, Geological Society of America Bulletin, 101: pp. 1465-1480.

Davis, E. E., and Currie, R. G. 1993. Geophysical observations of the northern Juan de Fuca Ridge and the East Pacific Rise, Annals of Geophysics, 11: pp. 532-541.

Dethier, D. P., Pessl, Fred Jr., Keuler, R. F., Balzarini, M. A. and Pevear, D. R. 1995. Late Wisconsinan glaciomarine deposition and isostatic rebound, northern Puget Lowland, Washington, Geological Society of America Bulletin, 107: pp. 1288-1303. 
Kovanen, D. J., and Easterbrook, D. J., and Thomas, P.A., 2001, Holocene eruptive history of Mt. Baker, Washington: Canadian Journal of Earth Sciences, 38, pp. 1355-1366.

Ehrenberg, C. G. 1861. Elemente des tiefen meeresgrundes in Mexikanischen Golfstrome bei Florida; ueber die tiefgrund-verhältnisse des Oceans am eingang der Davisstrasse und bei Island, Königlich preussischen Akademie der Wissenschaften zu Berlin, Monatsberichte: pp. 275-315.

Enkin, R. J., Dallimore, A., Baker, J., Southon, J. R. and Ivanochko, T. 2013. A new high-resolution radiocarbon Bayesian age model of the Holocene/Late Pleistocene from core MD02-2494 and others, Effingham Inlet, British Columbia, Canada; with an application to the paleoseismic event chronology of the Cascadia Subduction Zone, Canadian Journal of Earth Sciences, 50: pp. 746-760, doi:10.1139/cjes-2012-0150.

Enkin, R. J., Hamilton, T. S., Riedel, M., and Pohlman, J. 2010. Gravity Driven Slumps and Turbidites from the Frontal Ridge of Cascadia's Accretionary Wedge, Canada: Controls from Deglacial Sedimentation, Tectonics and Gas Hydrates. Abstract OS13D-06. Eos Transactions of the American Geophysical Union, Meeting of the Americas Supplement, 91(26): pp. 20.

Goldfinger, C., Nelson, C. H., and Johnson, J. E. 2003. Holocene earthquake records from the Cascadia subduction zone and northern San Andreas fault based on precise dating of offshore turbidites, Annual Reviews of Earth and Planetary Science, 31: pp. 555-577.

Goldfinger, C., Nelson, C. H., Morey, A. E., Johnson, J. R., Patton, J., Karabanov, E., Gutierrez-Pastor, J., Eriksson, A. T., Gracia, E., Dunhill, G., Enkin, R. J., Dallimore, A. and Vallier, T. 2012. Turbidite event history - Methods and implications for Holocene paleoseismicity of the Cascadia Subduction Zone, United States Geological Survey Professional Paper 1661-F: 170 p.

Govers, R., and Meijer, P.T. 2001. On the dynamics of the Juan de Fuca plate, Earth and Planetary Science Letters, 189: pp. 115-131.

Griggs, G. B., and Kulm, L. D. 1970. Sedimentation in Cascadia deep-sea channel, Geological Society of America Bulletin, 81: pp. 1361-1384. 
Gripp, A. E. and Gordon, R. G. 1990. Current Plate Velocities Relative to the Hotspots Incorporating the Nuvel-1 Global Plate Motion Model, Geophysical Research Letters, 17: pp. 1109-1112.

Haacke, R, Riedel, M., Pohlman, J., Rose, K., Lapham, L., Hamilton, T. S., Enkin, R. J., Spence, G., Hyndman, R. 2008. A recent investigation of gas hydrate as a factor in northern Cascadia accretionary margin frontal ridge slope failures and cold seep biogeochemistry, Eos Transactions, American Geophysical Union, 89: Abstract \#OS32A-07.

Hagstrom, J. T., Atwater, B. F. and Sherrod, B. L. 2004. Paleomagnetic correlation of late Holocene earthquakes among estuaries in Washington and Oregon, Geochemistry Geophysics Geosystems, 5: 18 p.

Hamilton, T. S., Esteban, L., and Enkin, R. J. 2010. Petrographic, geochemical and magnetic properties of carbonate rock formation and low temperature diagenetic alteration of unconsolidated sediments accompanying the formation of gas hydrate deposits, Proceedings of the 14th Symposium on the Geology of the Bahamas and other carbonate regions: pp. 107-130.

Hensen, C., Zabel, M., Pfeifer, K., Schwenk, T., Kasten, S., Riedinger, N., Schulz, H.D., and Boetius, A. 2003. Control of sulfate pore-water profiles by sedimentary events and the significance of anaerobic oxidation of methane for the burial of sulfur in marine sediments, Geochimica et Cosmochimica Acta, 67: pp. 2631-2647, DOI: 10.1016/S0016-7037(03)00199-6

Hilbrecht, H. 1996. Extant planktic foraminifera and the physical environment in the Atlantic and Indian Oceans.- Mitteilungen aus dem Geologischen Institut der Eidgenössischen Technischen Hochschule und der Universität Zürich, Neue Folge. 300: 93 p.

Hughen, K.A., Baillie, M. G. L., Bard, E. and 25 others 2004. Marine04 - Marine radiocarbon age calibration, 26-0 ka BP. Radiocarbon, 46: pp. 1059-1086.

Hutchinson, I., James, T. S., Reimer, P. J., Bornhold, B. D., and Clague, J. J. 2004. Marine and limnic radiocarbon reservoir corrections for studies of late- and postglacial environments in Georgia Basin and 
Puget Lowland, British Columbia, Canada and Washington, USA. Quaternary Research, 61: pp. 193203.

Hyndman, R. D., Riddihough, R. P., and Herzer, R. 1979. The Nootka Fault Zone - a new plate boundary off Western Canada., Geophysical Journal of the Royal Astronomical Society, 58: pp. 667-683.

Kaneko, M., Shingai, H., Pohlman, J. W., and Naraoka, H. 2010 Chemical and isotopic signature of bulk organic matter and hydrocarbon biomarkers within mid-slope accretionary wedge sediments of the northern Cascadia margin gas hydrate system, Marine Geolology, 275: pp. 66-177.

Kucera, M., Weinelt, M., Kiefer, T., Pflaumann, U., Hayes, A., Weinelt, M., Chen, M.-T., Mix, A. C., Barrows, T. T., Cortijo, E., Duprat, J., Juggins, S., and Waelbroeck, C. 2005. Reconstruction of seasurface temperatures from assemblages of planktonic foraminifera: multi-technique approach based on geographically constrained calibration data sets and its application to glacial Atlantic and Pacific Oceans, Quaternary Science Reviews, 24: pp. 951-998.

Leonard, L.J., Rogers, G.C., and Mazzotti, S. 2012. A preliminary tsunami hazard assessment of the Canadian Coastline. Geological Survey of Canada, Open File 7201: 126 p. doi:10.4095/292067.

Lopez, C., Spence, G. D., Hyndman, R. D., and Kelly, D. 2010. Frontal slope failure at northern Cascadia margin: Margin-normal fault and gas hydrate control, Geology, 38: pp. 967-970, doi:10.1130/G31136.1.

Lowe, D.R. 1982. Sediment gravity flows: II. Depositional models with special reference to the deposits of high-density turbidity currents. Journal of Sedimentology, Society of Economic Paleontologists and Mineralogists, 52: 279-297.

Mazzotti, S., Leonard, L. J., Cassidy, J. F., Rogers, G., and Halchuk, S. 2011. Seismic Hazard in Western Canada from GPS Strain Rates Versus Earthquake Catalog, Journal of Geophysical Research, 116: B12310, doi:10.1029/2011JB008213.

Morgenstern, N.R. 1967. Submarine slumping and the initiation of turbidity currents. In: Richards, AF eds. (1967) Marine Geotechnique. University of Illinois Press, Urbana, Illinois, pp. 189-220. 
Nelson, A. R., Kelsey, H. M. and Witter, R. C. 2006. Great earthquakes of variable magnitude at the Cascadia subduction zone. Quaternary Research, 65: pp. 354-365.

Obana, K., Scherwath, M., Yamamoto, Y., Kodaira, S., Wang, K., Spence, G., Riedel, M., and Kao, H., 2015. Earthquake Activity in Northern Cascadia Subduction Zone Off Vancouver Island Revealed by Ocean-Bottom Seismograph Observations. Bulletin of the Seismological Society of America, 105: pp. 489-495.

Pohlman, J. W., Canuel, E. A., Chapman, N. R., Spence, G. D., Whiticar, M. J., and Coffin, R.B. 2005. The origin of thermogenic gas hydrates on the northern Cascadia Margin as inferred from isotopic $(13 \mathrm{C} / 12 \mathrm{C}$ and $\mathrm{D} / \mathrm{H})$ and molecular composition of hydrate and vent gas, Organic Geochemistry, 36: pp. 703-716.

Pohlman, J. W., Kaneko, M., Heuer, V. B., Coffin, R. B. and Whiticar, M. 2009. Methane sources and production in the northern Cascadia margin gas hydrate system, Earth and Planetary Science Letters, 287: pp. 504-512.

Pohlman, J. W., Riedel, M., Bauer, J. E., Canuel, E. A., Paull, C. K., Lapham, L., Grabowski, K., Coffin, S. R. B., and Spence, G. D. 2013. Anaerobic methane oxidation in low-organic content methane seep sediments, Geochimica et Cosmochimica Acta, 108: pp. 184-201.

Pohlman, J. W., Riedel, M., Waite, W., Rose, K., Lapham, L., Hamilton, T. S., Enkin, R. J., Spence, G. D., Hyndman, R. D., and Haacke, R. 2008. Geochemical Investigation of Slope Failure on the Northern Cascadia Margin Frontal Ridge, Eos Transactions, American Geophysical Union, 89: Abstract \#OS32A-08.

Reimer, P. J., Baillie, M. G. L., Bard, E., Bayliss, A., Beck, J.W., Blackwell, P. G., Ramsey, C. B., Buck, C. E., Burr, G. S., Edwards, R. L., Friedrich, M., Grootes, P. M., Guilderson, T. P., Hajdas, I., Heaton, T. J., Hogg, A. G., Hughen, K. A., Kaiser, K. F., Kromer, B., McCormac, F. G., Manning, S. W., Reimer, R.W., Richards, D. A., Southon, J. R., Talamo, S., Turney, C. S. M., van der Plicht, J., and 
Weyhenmeye, C. E. 2009. IntCal09 and Marine09 radiocarbon age calibration curves, 0-50,000 years cal BP, Radiocarbon, 51: pp. 1111-1150.

Reynolds, L. A., and Thunell, R. C. 1986. Seasonal Production and Morphologic Variation of Neogloboquadrina pachyderma (Ehrenberg) in the Northeast Pacific, Micropaleontology, 32: pp. 1-18.

Riedel, M., Novosel, I., Spence, G. D., Hyndman, R. D., Chapman, R. N., Solem, R. C., Lewis, T., and Zuelsdorff, L. 2006. Geophysical and geochemical signatures associated with gas hydrate related venting at the northern Cascadia margin, Geological Society of America Bulletin, 118: pp. 23-38.

Riedel, M., and Rohr, K. M. M. 2012. Gas Hydrate within the Winona Basin, Offshore western Canada, Marine and Petroleum Geology, 30: pp. 66-80.

Riedel, M., Spence, G. D., Chapman, N. R., and Hyndman, R. D. 2002. Seismic investigations of a vent field associated with gas hydrates, offshore Vancouver Island, Journal of Geophysical Research, 107: EPM pp. 5-1 to 5-16.

Ristau, J. 2004. Seismotectonics of Western Canada from Moment Tensor Analysis, Ph.D. Thesis, University of Victoria, 209 p.

Robinson, S.W., and Thompson, G. 1981. Radiocarbon corrections for marine shell dates with application to southern Pacific Northwest Coast prehistory, Syesis, 14: pp. 45-57.

Satake, K., Shimazaki, K., Tsuji, Y., and Ueda, K. 1996. Time and size of a giant earthquake in Cascadia inferred from Japanese tsunami records of January 1700, Nature, 379: 246-249.

Su, X., Baumann, K.-H., and Thiede, J. 2000. Calcareous Nannofossils From Leg 168: Biochronology And Diagenesis, in Fisher, A., Davis, E.E., and Escutia, C. (Eds.), Proceedings of the Ocean Drilling Program, Scientific Results, 168: pp. 39-49.

Spence, G. D., J. Hyndman, J., Chapman, N. R., Riedel, M., Edwards, N., and Yuan, J. 2000. Cascadia margin, northeast Pacific Ocean: hydrate distribution from geophysical investigations, In: Max, M.D. (Ed.), Natural Gas Hydrate in Oceanic and Permafrost Environments: Dordrecht (Kluwer Academic Publications), pp. 183-198. 
Talling, P. J. 2014. On the triggers, resulting flow types and frequencies of subaqueous sediment density flows in different settings. Marine Geology, 352: 155-182

Wada, I., Mazzotti, S., and Wang, K. 2010. Intraslab Stresses in the Cascadia Subduction Zone from Inversion of Earthquake Focal Mechanisms, Bulletin of the Seismological Society of America, 100: pp. 2002-2013. 
List of Figure Captions for T. S. Hamilton et al Slipstream paper

Figure 1. The tectonics for this figure was redrawn from original sources and assembled for this paper. The approximate location of the Cascadia Subduction Zone was from Nelson et al. (2006) and refined using the multibeam University of Washington high resolution bathymetry. The ridge system was drawn from Cousens (2010) and data in the NOAA/PMEL/VENTS website: from Stace Beaulieu (WHOI), Mark Hannington (University of Ottawa, Canada), Ed Baker (NOAA/PMEL, USA), and Sven Petersen (IFM-GEOMAR, Germany). The seismotectonics boundaries of the Juan de Fuca, Explorer Plate and fracture zones came from a distillation of interpretations in: Braunmiller and Nabelek (2002), Cowan et al. (1986), Davis and Currie (1993), Govers and Meijer (2001), Hyndman et al. (1979), Riedel and Rohr (2012), Ristau (2004), Wada et al. (2010). a) Plate tectonic context for Cascadia paleoseismology studies: NP, North American Plate; PP, Pacific Plate; JP Juan de Fuca Plate; EP, Explorer Plate; WB, Winona Basin; CSZ, Cascadia Subduction Zone; JR, Juan de Fuca Ridge; WV, West Valley; MV, Middle Valley; SFZ, Sovanco Fracture Zone; EX, Explorer Seamount; ER, Explorer Ridge; RFZ, Revere Fault Zone; DFZ; Delwood Fracture Zone; DK: Dellwood Knolls; TW; Tuzo Wilson Seamounts; QCF, Queen Charlotte Fault; NFZ, Nootka Fault Zone; BFZ, Brooks Fault Zone; AW, Accretionary Wedge; CS, Continental Shelf; JFS, Juan de Fuca Strait. b) Enlargement of the University of Washington multibeam seafloor topography between Slipstream Slump and Barkley Canyon, indicating coring sites from Geological Survey of Canada GSC cruise 2008007PGC (this paper), University of Oregon cruise M9907 (Goldfinger et al., 2012).c) Enlargement of Slipstream Slump, revealing the rotational block-slide geometry and the coring sites described in this paper. The limit of the debris field was imaged using SeaMark backscatter data (Davis and Hyndman, 1989). d) Multichannel seismic line GSC89-08 (indicated in plan view in b) revealing section geometry of the Cascadia accretionary wedge, the top of the ocean crust (the top of the basaltic crust is marked by the strongest reflector at 5.5 seconds two way time) as well as indicating the coring sites of IODP Expedition 311. 
Figure 2. a) Pore-water Chloride ion and b) Sulfate ion concentrations analyzed by ion chromatography as a function of depth in centimeters below seafloor for Cores 7, 9, 10, 11 and 25. Reference values for seawater are indicated by the vertical gray bars.

Figure 3. Representative photographs of split cores (locations are given in Table 1), illustrating the 5 principal sedimentary facies along with their lithological interpretations and Munsell soil colours. a) Core 7 from the toe of the debris flow, containing hemipelagic sediments overlain by proximal turbidite SS4. b) Core 25 from the headwall scarp, containing sediments from the original debris flow overlain by cohesive slide block of deglacial diamicton representative of the main sedimentary accumulation in the region. c) Core 11 from the base of the headwall scarp pierced through to underlying Pleistocene glauconitic biogenic ooze covered at a convoluted interface by proximal turbidite (Bouma A) sediments. Radiocarbon ages are as per Table 2 and the discussion in the paper.

Figure 4. Magnetic susceptibility logs $\left(10^{-5} \mathrm{SI}\right.$ units $)$ of the upper portions of Cores 10,9 and 7 taken across the toe of the Slipstream Slump are correlated to Barkley Canyon and Effingham Inlet coring sites. The hemipelagic mud (white) are interfingered with turbidites (light grey or coloured). These layers are identified as events SS1 through SS12 at Slipstream and correlated event numbers at Barkley Canyon and Effingham Inlet, based on a combination of sedimentological properties such as: relative sand thicknesses, upwards fining sequences and proxy physical properties observations in addition to their interval positions. The Holocene mud/turbidite package overlies the initial slump (medium grey). Radiocarbon data from planktonic foraminifera collected from hemipelagic sediments are indicated by dark grey sample ranges and uncalibrated ${ }^{14} \mathrm{C}$ ages $\pm 1 \sigma$ years BP (1950) from the lab outputs as per Table 2. The Slipstream dates were all performed at Woods Hole Oceanographic Institute. The Barkley Canyon dates mostly come from Lawrence Livermore with a few from UC Irvine as per 
Goldfinger et al. (2012). The Effingham Inlet record is based on 68 radiocarbon dates from UC Irvine and the Mazama ash as per Enkin et al. (2013).

Figure 5. Uncalibrated radiocarbon ages for the last a) $15 \mathrm{ka}$ for Cores 7, 9 and 11 and b) for the last $50 \mathrm{ka}$ for Cores 7, 9, 11 and 25. Note the different horizontal time scales for figure parts a and b but the data presented on both panels are identical. For only the oldest ages (Core 11 375-378 cmbsf and Core 25 363-368 cmbsf), the radiocarbon measurement $1 \sigma$ confidence interval is wider than the dot. Taken individually, the core age models are distinct, but a common age model is established by taking the sedimentary facies into account. Note that the upper portions of Cores 7 and 9 are nearly linear (i.e., near constant sedimentation rate), and deeper down most ages fall in the late deglacial age range of 13 to $14 \mathrm{ka} \mathrm{BP.}$

Figure 6. Summary model of the development the frontal ridge, Slipstream Slump and its sedimentary record, combining sedimentary observations, regional age constraints, bathymetry (Fig. 1c) and the single channel seismic section (e). a) $>44$ ka Interglacial to glacial maximum age biogenic ooze and hemipelagic sediments drape the abyssal plain and continental slope off Vancouver Island as frontal thrusts in the Cascadia accretionary prism form and elevate the frontal ridge. b) 17 A large accumulation of ice-rafted debris (IRD) accompanies the deglaciation of the Wisconsinan icesheets (Juan de Fuca Strait, Vancouver Island) while the frontal ridge continues to form. c) 11 ka The Slipstream Slump fails, along with a paired failure into the slope basin on the eastern flank of the ridge. d) Modern setting wherein hemipelagic sediments have accumulated with interbedded turbidites on top of the original slump with subsequent debris shed from the steep scarp as triggered by earthquakes. e) Single channel seismic section (coincident to line shown in Fig. 1d) with piston core positions, abyssal plain, deformed frontal ridge and slope basins. 
Figure 7. Age models against the Event Free Depth, which is the accumulated depth of hemipelagic sediments after removal of the thicknesses of the turbidite sediments, based on Core $7 . \mathrm{Each}{ }^{14} \mathrm{C}$ date is represented by the shape of its likelihood function. The OxCal prior calibrated likelihood curves for the radiocarbon ages are coloured white, while the posterior likelihood using a Poisson-process sedimentation model with $\mathrm{k}=2 \mathrm{~cm}^{-1}$, are coloured as in each part's legend. Prior likelihood distributions for outliers (excluded from age model) are inverted. The marine reservoir is $\mathrm{R}=400$ years, $\Delta \mathrm{R}=0 \pm 50$ years, except for part c. Turbidite horizons are indicated with dashed horizontal lines with locality labels. The a priori age distribution for the top of the core is $-58 \pm 200$ years (see text). a) Slipstream Slump only, combined Core 7 and 9 age model. Note the expanding uncertainties above and below the dated interval. b) The preferred model for this paper, combining Slipstream Slump and Barkley Canyon planktonic ages. c) Same as part $b$, but with marine reservoir $R=820$ years, $\Delta R=420 \pm 84$ years as used by Goldfinger et al., 2012. d) Ages of turbidite (debris flow) events from Effingham Inlet (Enkin et al., 2013) with thicknesses $>10 \mathrm{~cm}$ are included in the Poisson-process age model demonstrating coherence with the Slipstream - Barkley Canyon data when $\Delta \mathrm{R}=0 \pm 50$. Note that the $95 \%$ confidence interval age model in part $d$ completely lies within that of part $b$. The choice of marine reservoir mainly introduces a static shift and the inter-seismic interval remains the same for hazard calculations.

Figure 8. Age versus geographic position chart of events interpreted as seismically generated observed along the northern portion of the Cascadia subduction zone, with proposed correlations based on age sequence with secondary information from inferences about degree of shaking from magnetic susceptibility, turbidite thicknesses and inter-seismic intervals. E: Effingham Inlet (Enkin et al., 2013); SS: Slipstream Slump (this paper); S: Saanich Inlet (Blais-Stevens et al., 2012); B: Barkley Canyon, J: Juan de Fuca Channel and C: Cascadia Channel (Goldfinger et al., 2012) and the letter-identified coseismic inundations from estuaries along the Washington Coast (Atwater et al., 2005; Hagstrum et al., 2004), with recent refinement to W age from Atwater and Griggs (2012). Ages for turbidites in Juan de 
Fuca Channel and Cascadia Channel are from Goldfinger (2012), Figure 52 and Appendix 1 "LandMarine compilation" Worksheet. Note that the Slipstream Slump has a record similar to other turbidite records with a recurrence interval of $\sim 400$ years up to and including the major event (SS3) around 6.6 ka, after which all records have a gap of $>1000$ years. After this event the record at Slipstream becomes more sparse which we interpret as the slope basin becoming sediment starved. 
Fig. 1
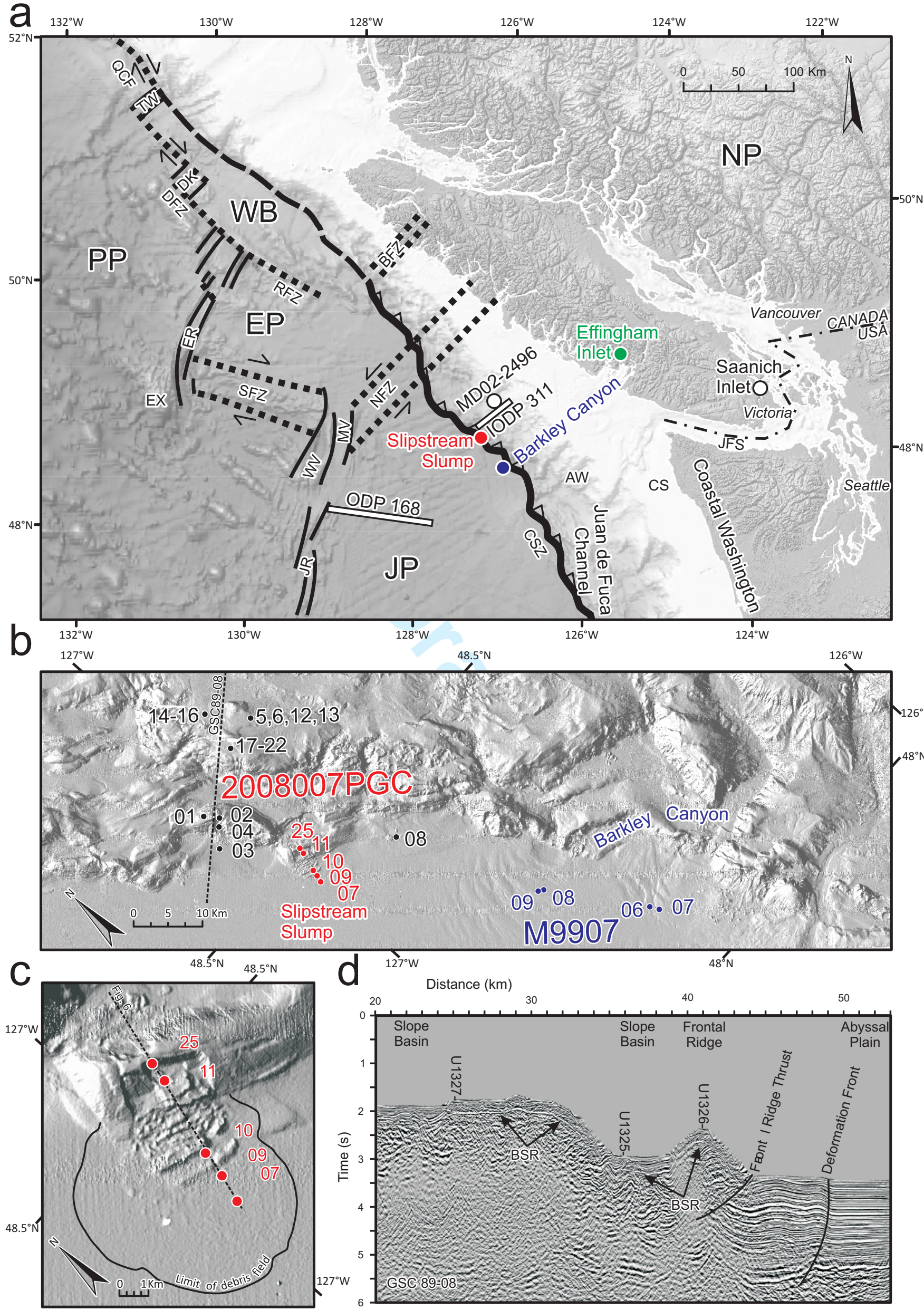

https://mc06.manuscriptcentral.com/cjes-pubs 
a

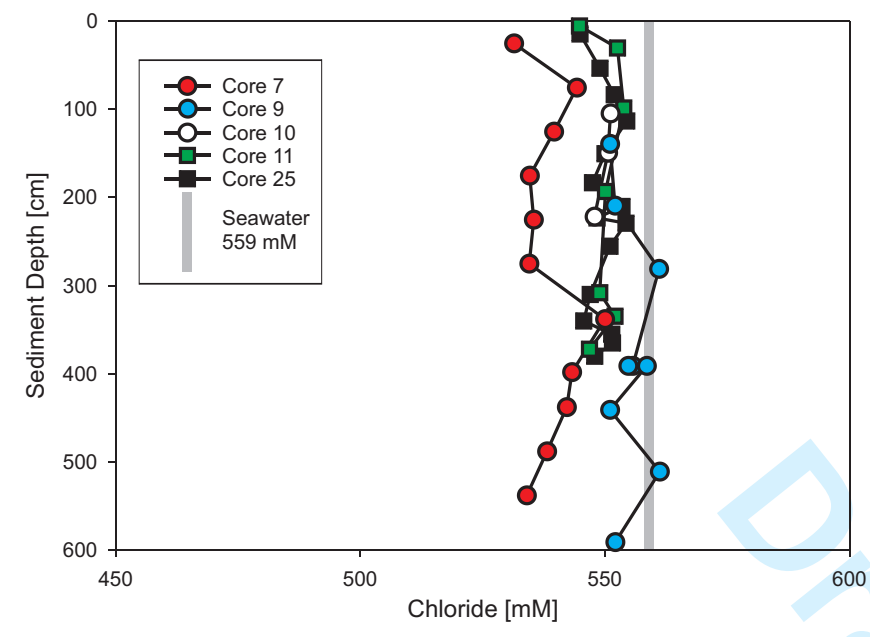

b

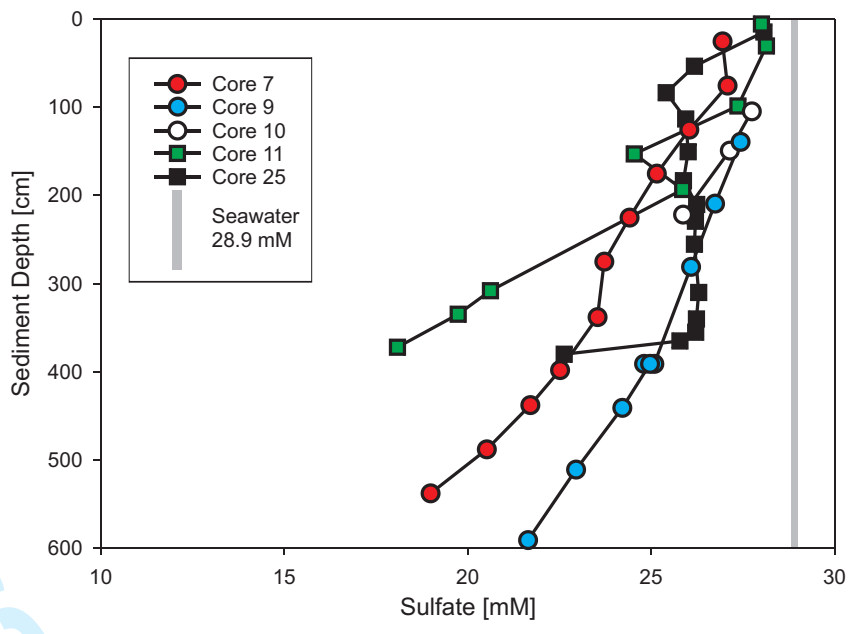



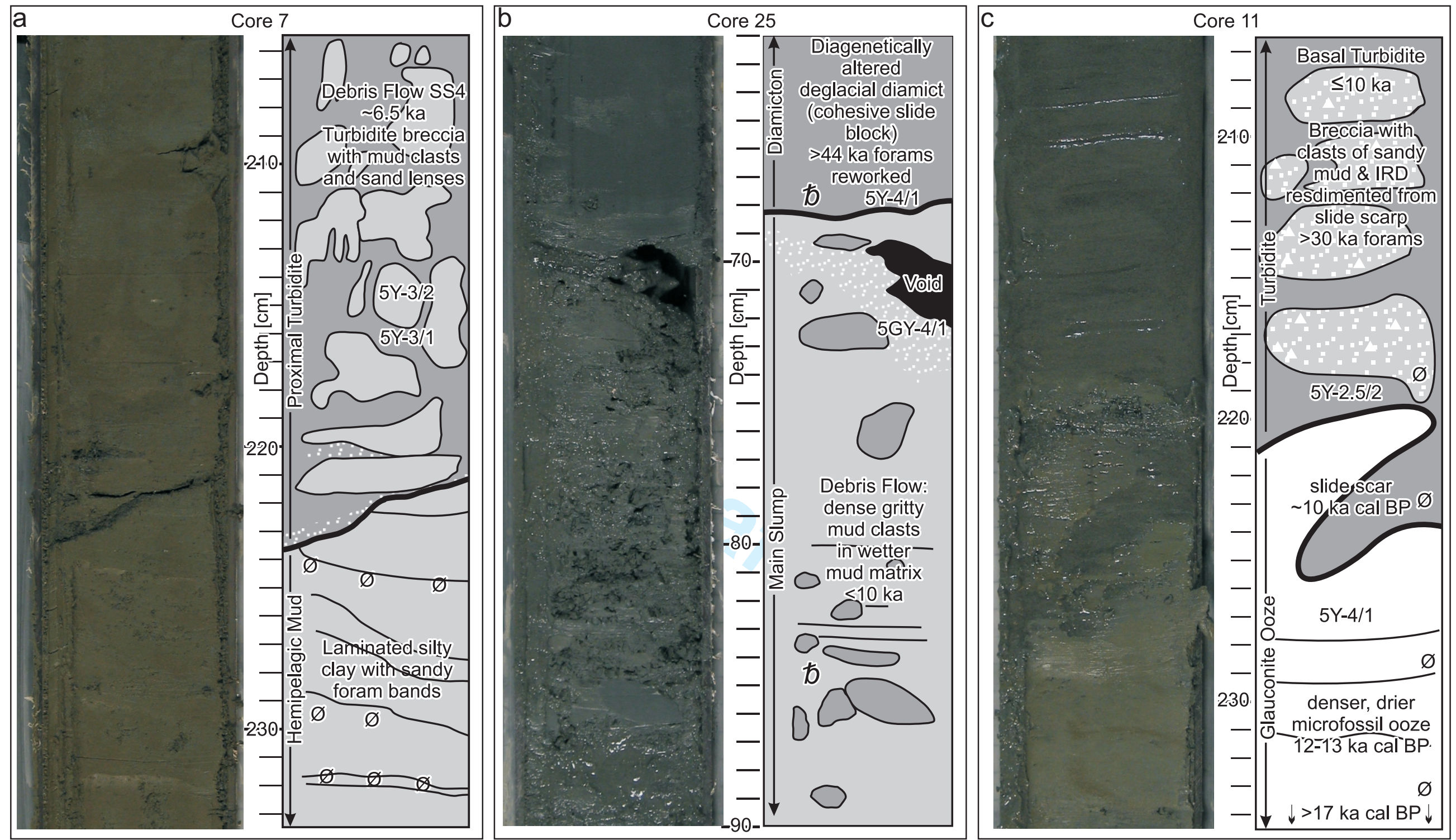

Fig. 3 


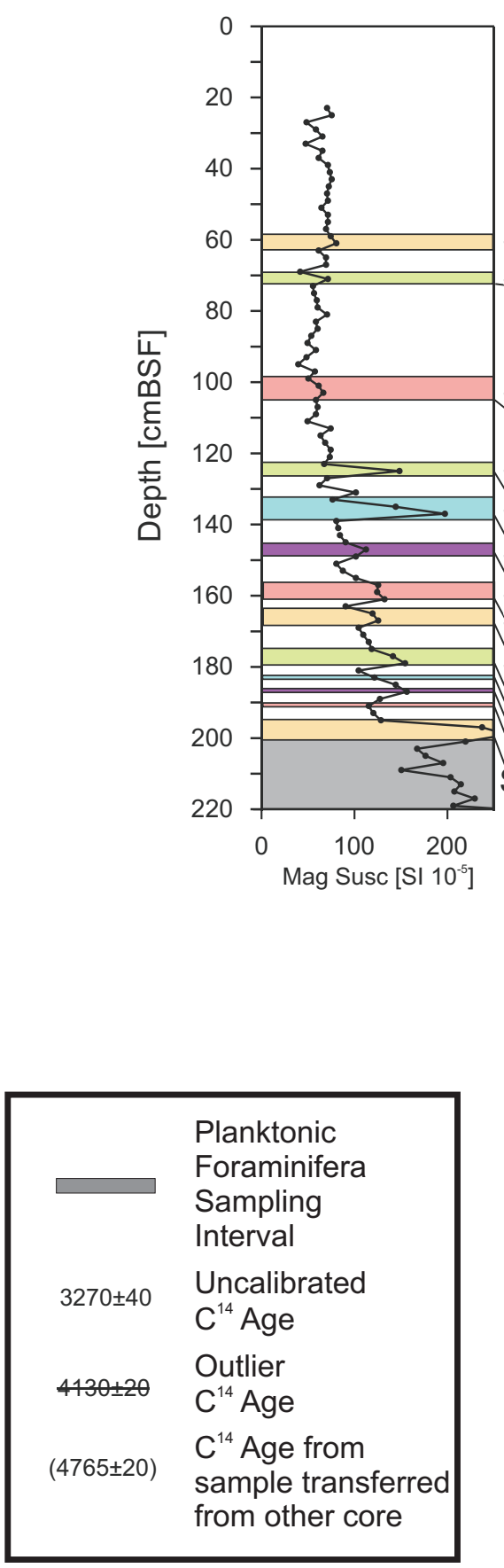

Fig. 4
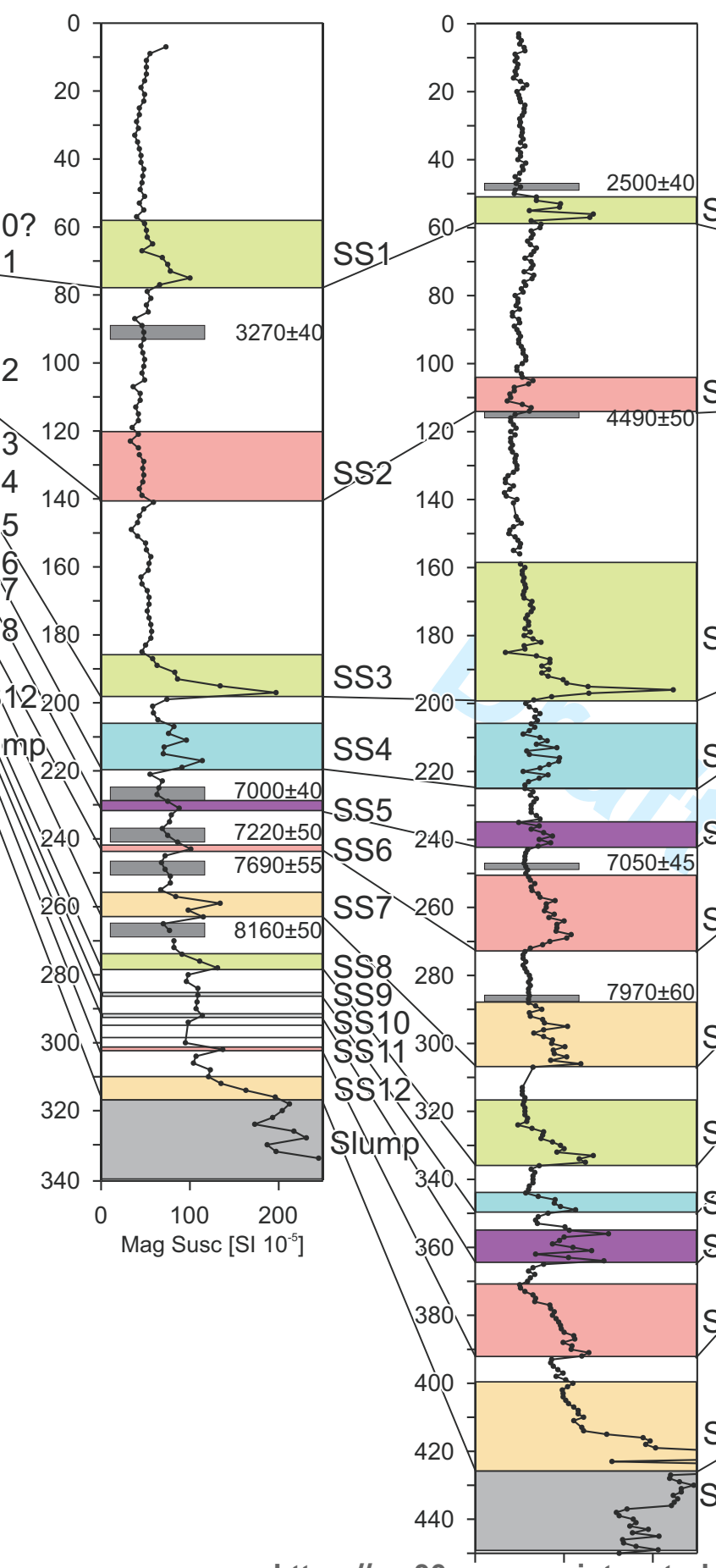

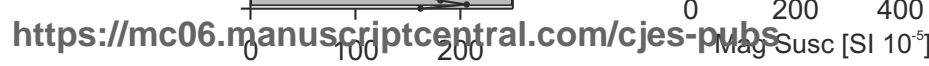
Mag Susc $\left[\right.$ SI 10 $\left.0^{-5}\right]$

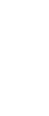


Fig. 5

a

Approx Cal Age $(\triangle \mathrm{R}=-100)$ [yr BP]

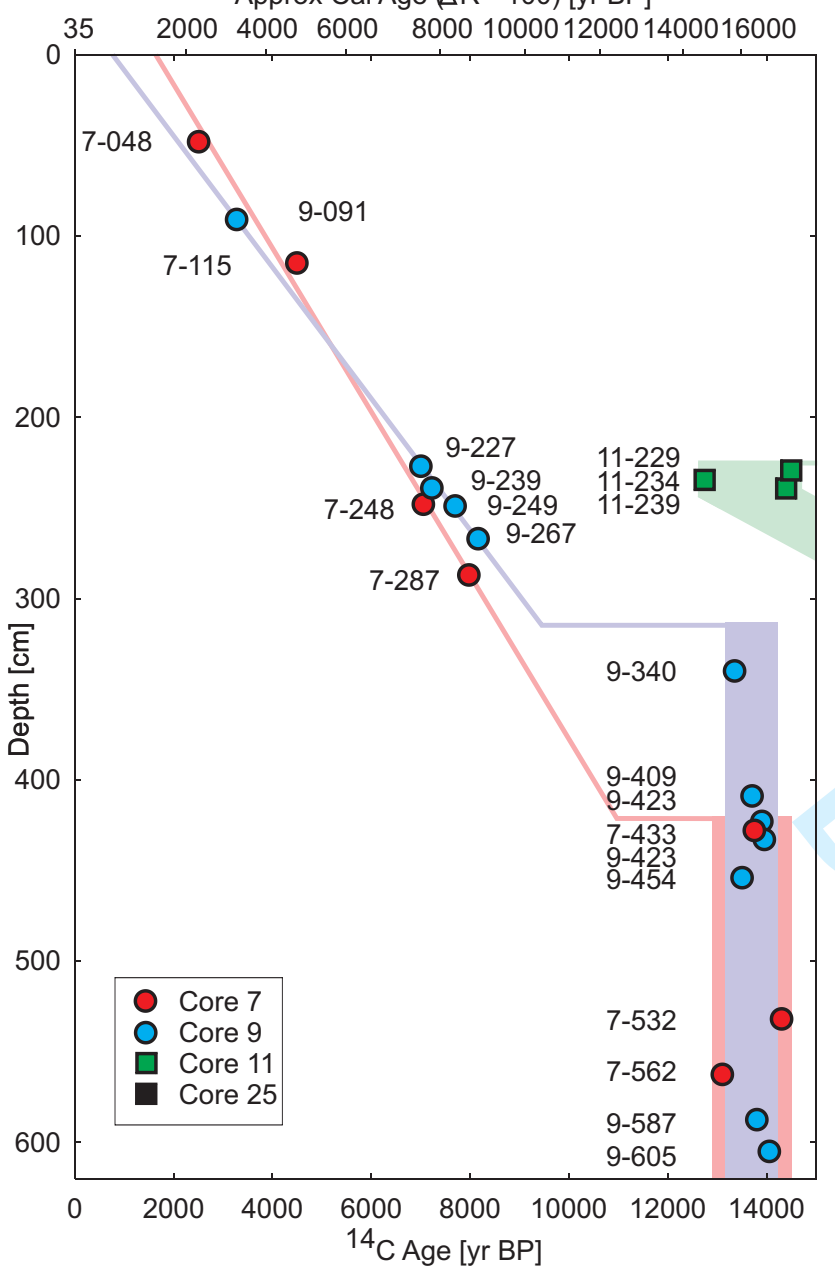

b

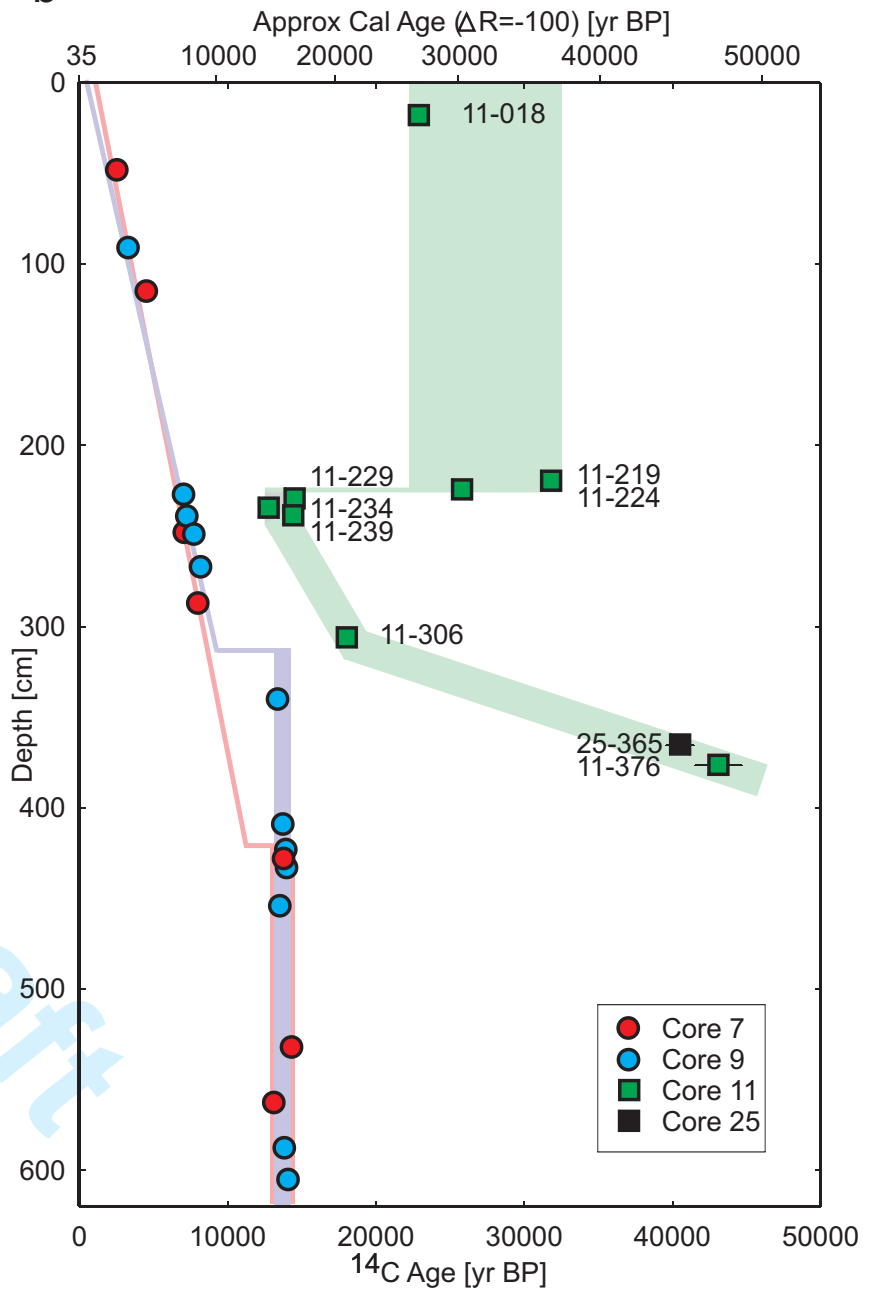



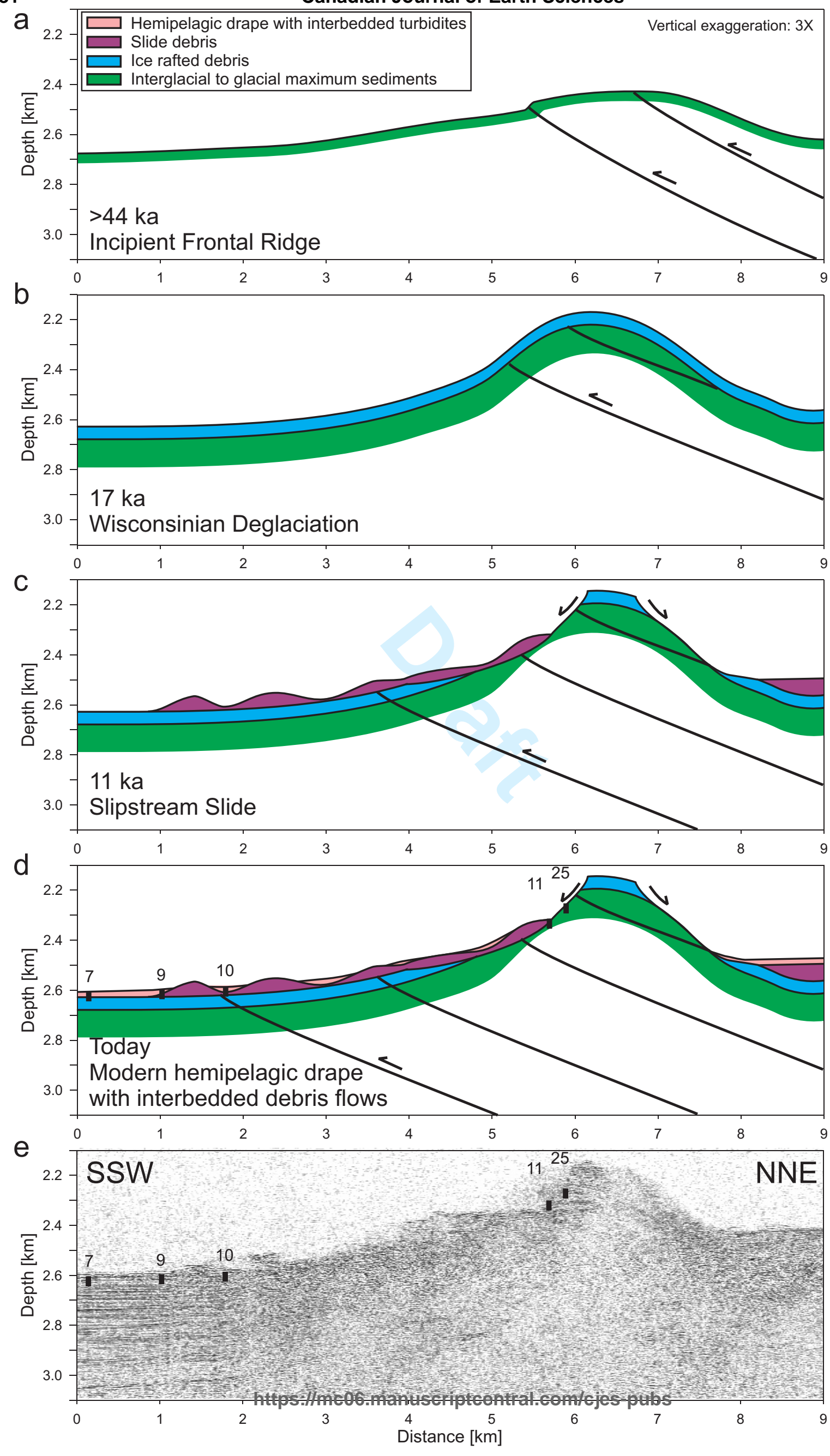
Fig. 7
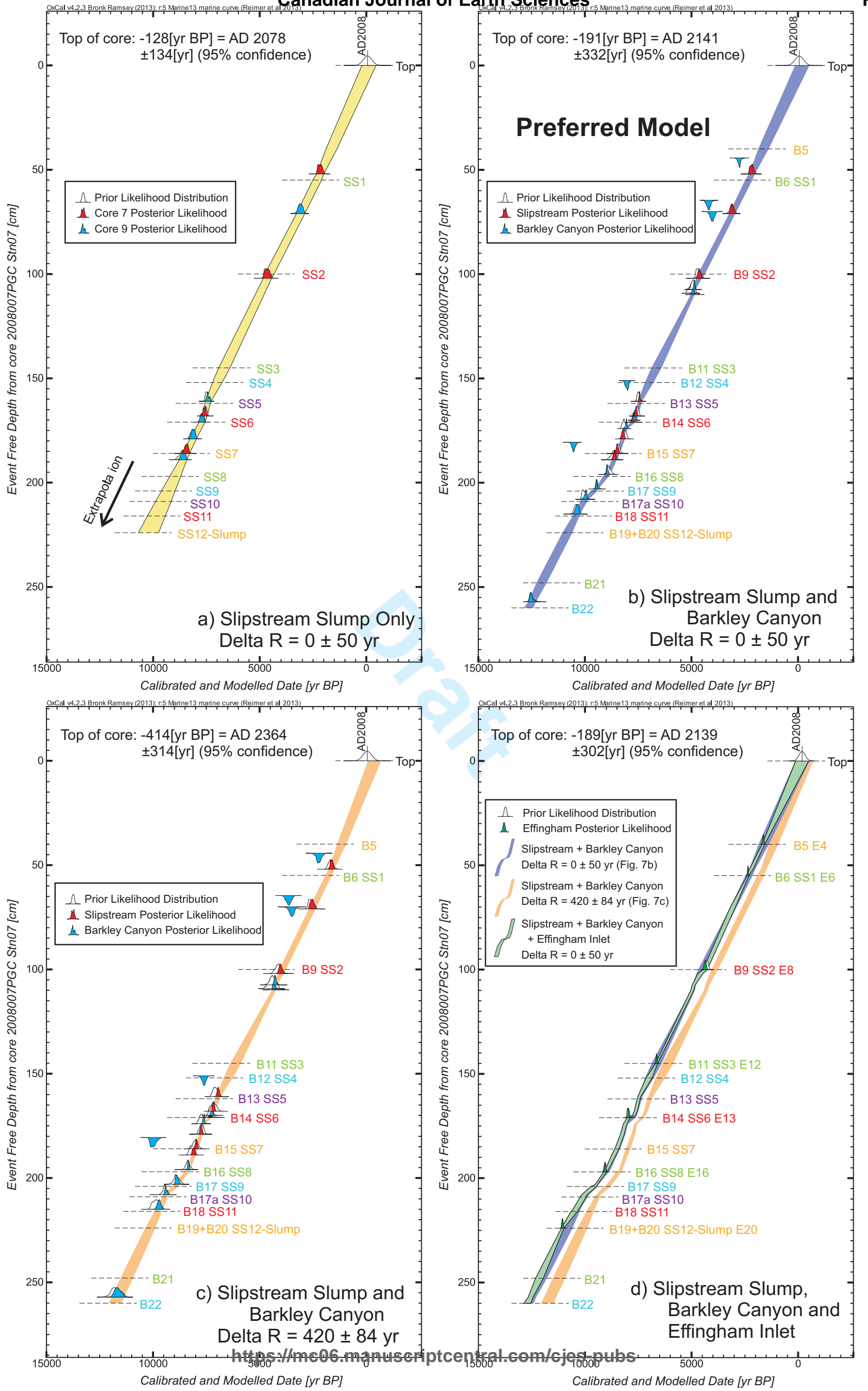


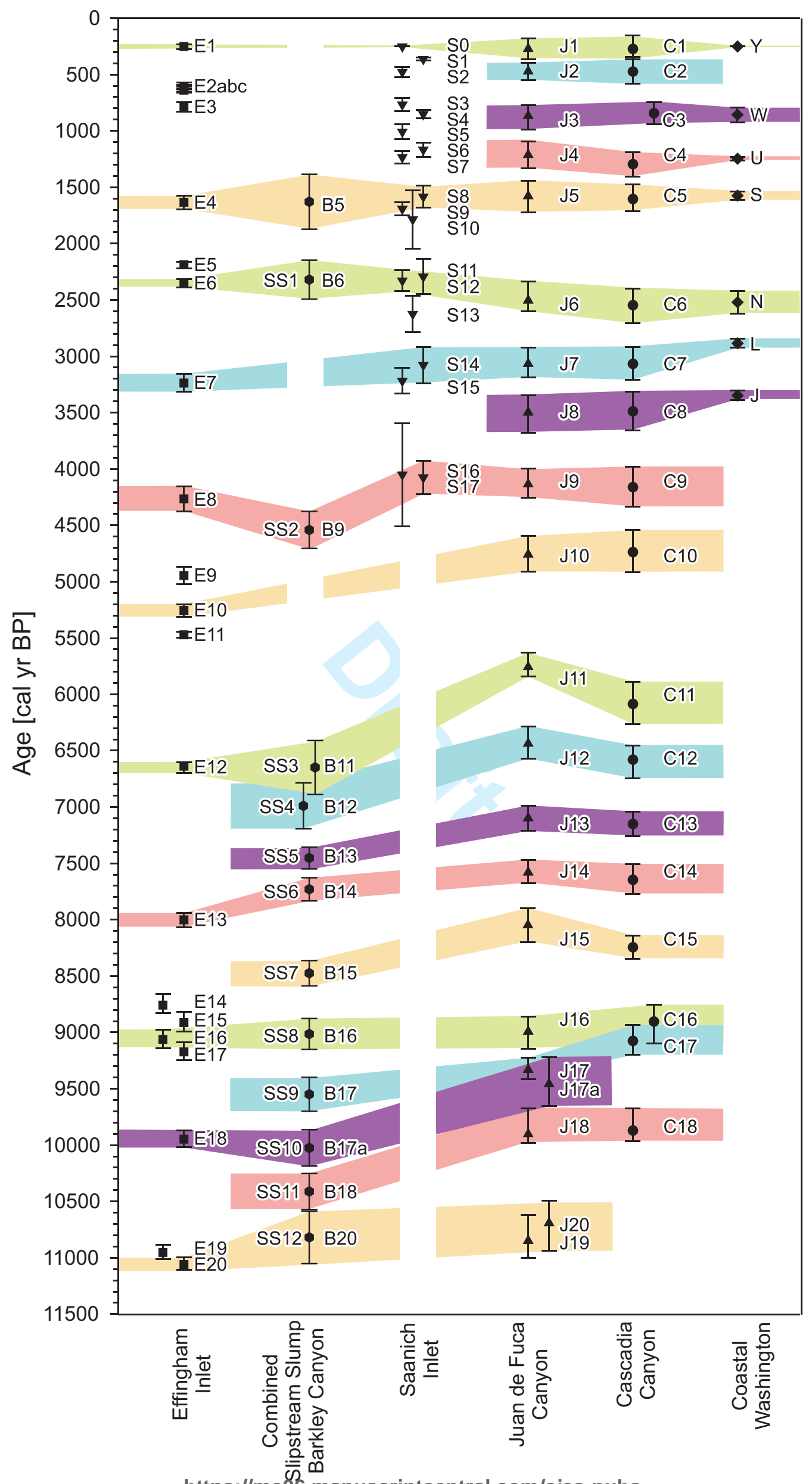

https://mc06.manuscriptcentral.com/cjes-pubs 
Fig. 1
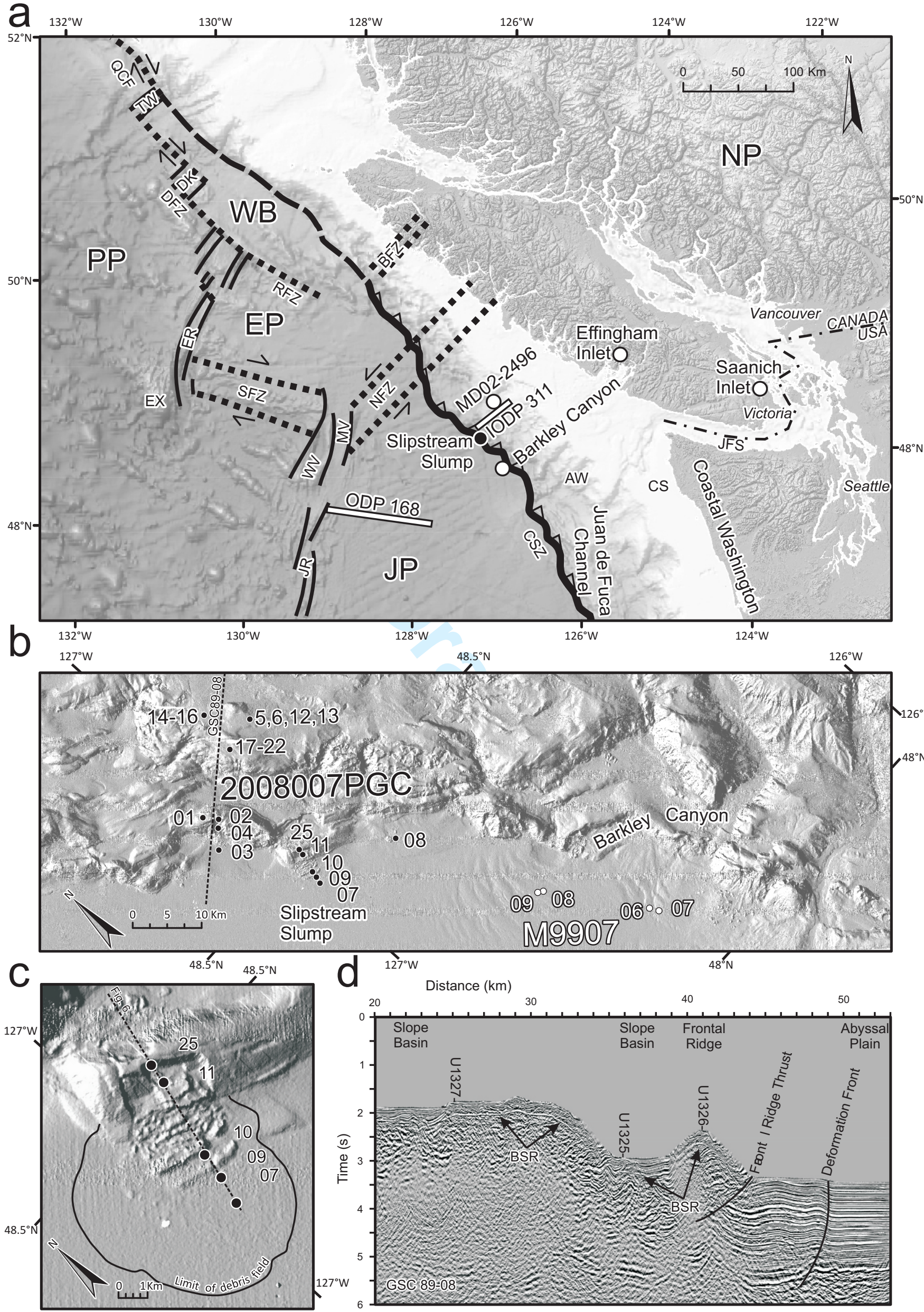

https://mc06.manuscriptcentral.com/cjes-pubs 

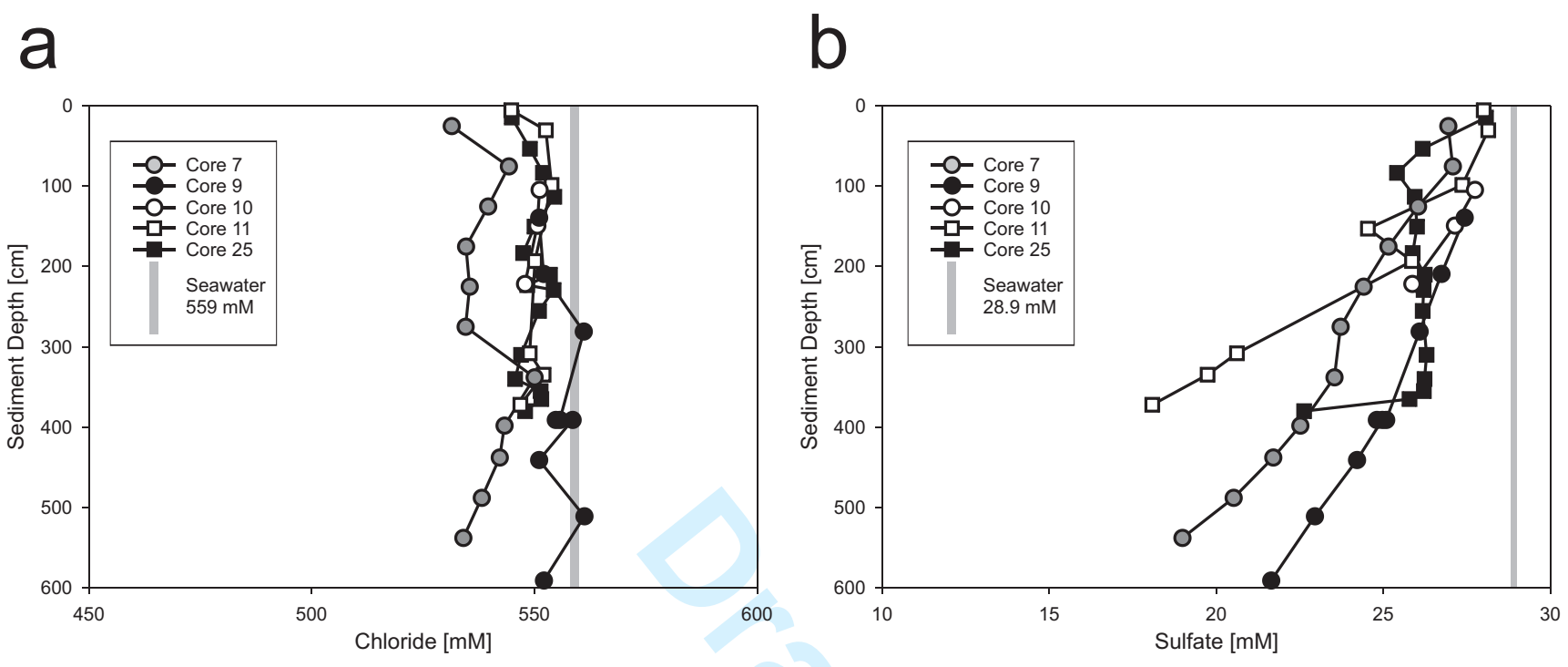

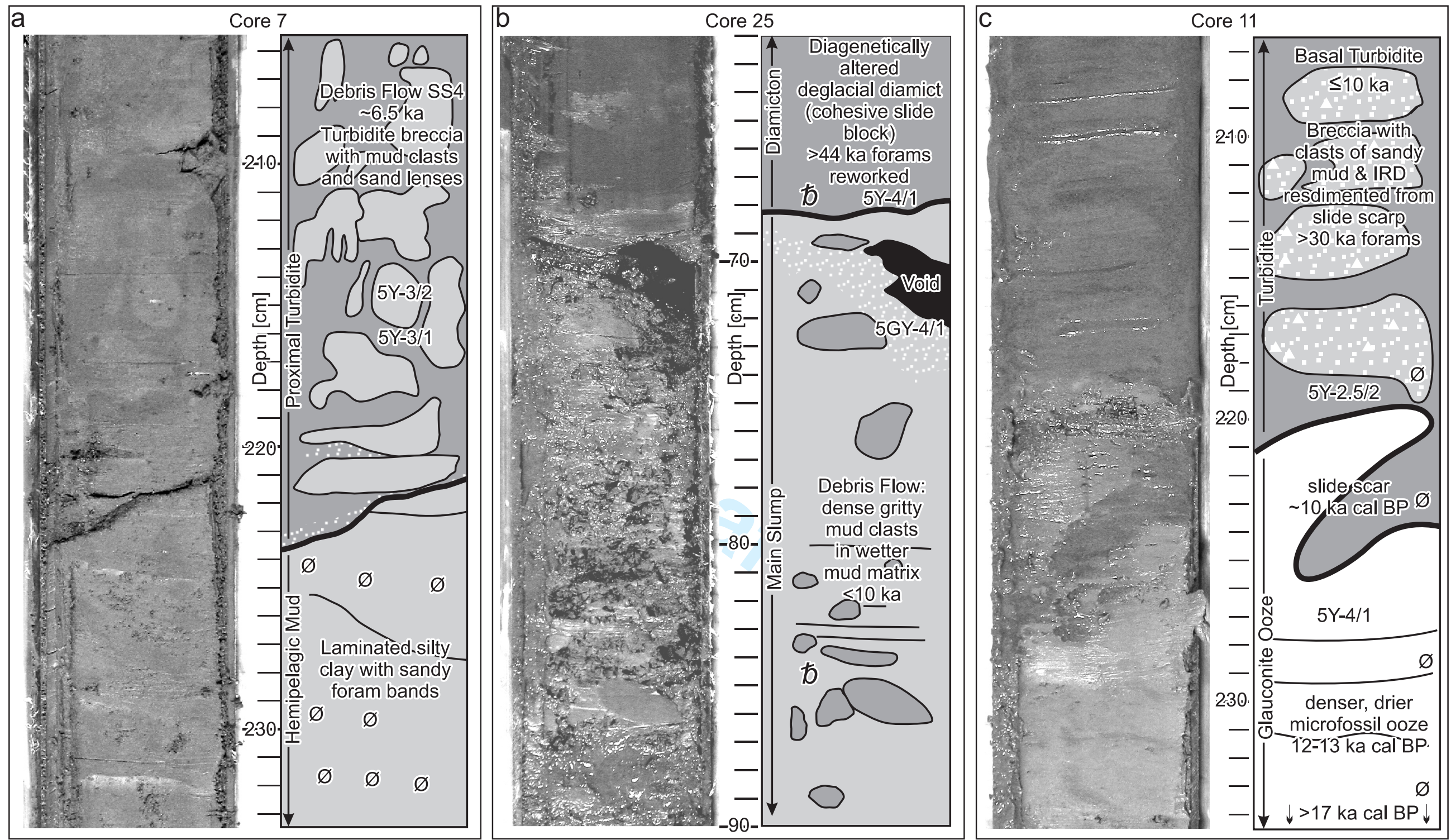

Fig. 3 


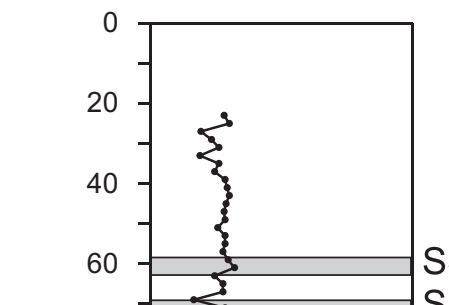

ए
क
है
동

80

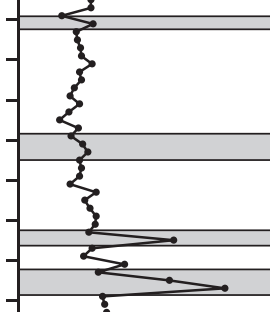

160

180

200

220

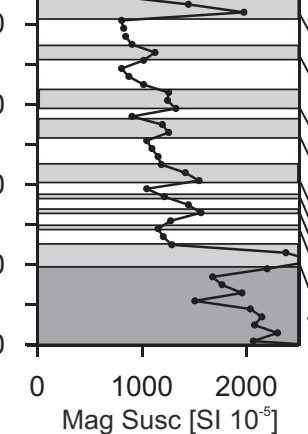

Planktonic

Foraminifera

Sampling

Interval

$3270 \pm 40 \quad$ Uncalibrated

$\mathrm{C}^{14}$ Age

$4130 \pm 20$

Outlier

$\mathrm{C}^{14}$ Age

(4765 \pm 20$) \quad C^{14}$ Age from

sample transferred from other core

Fig. 4
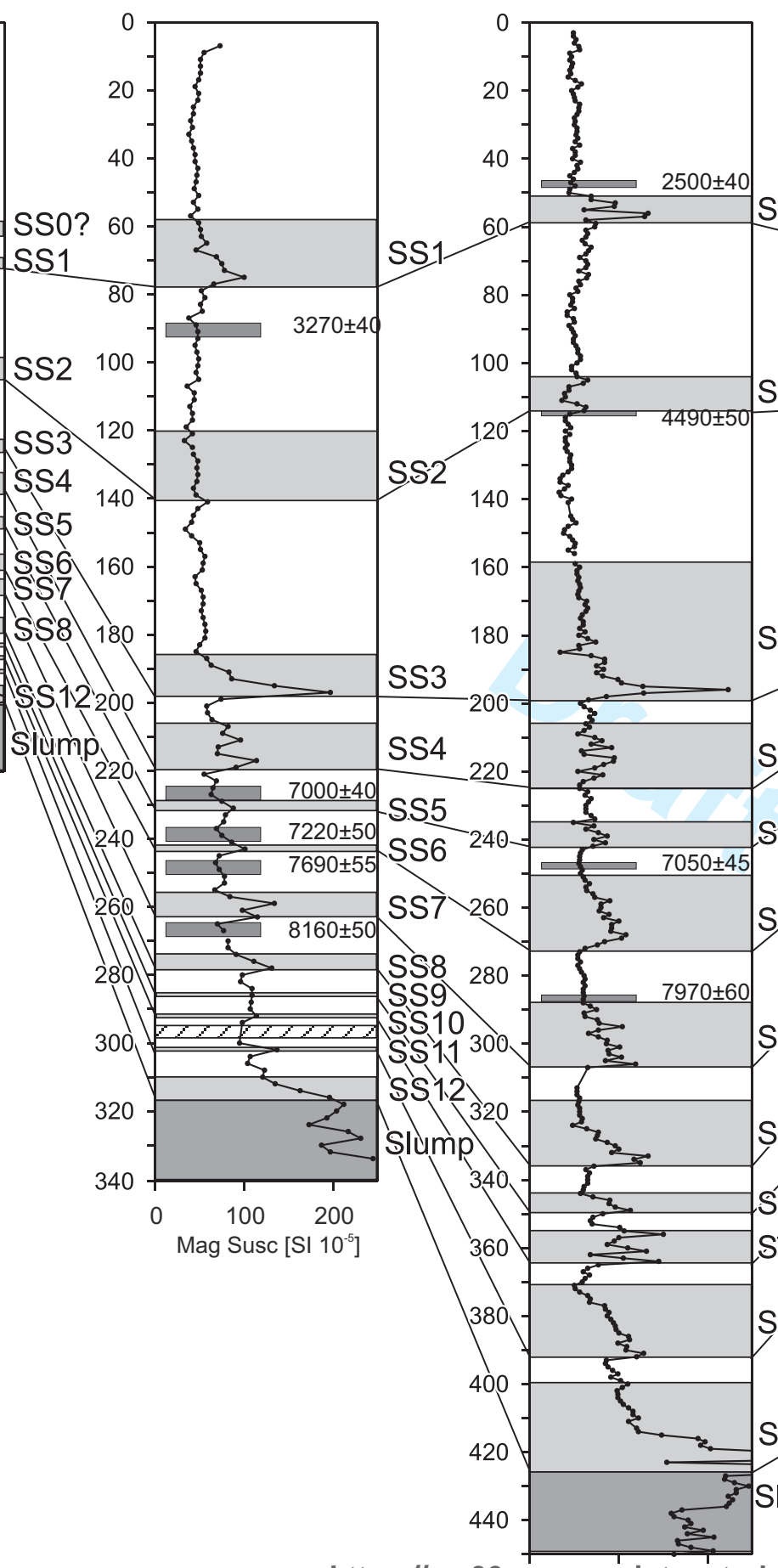

SS5

SSST 100

SS8 180

SS 12200

Slimp
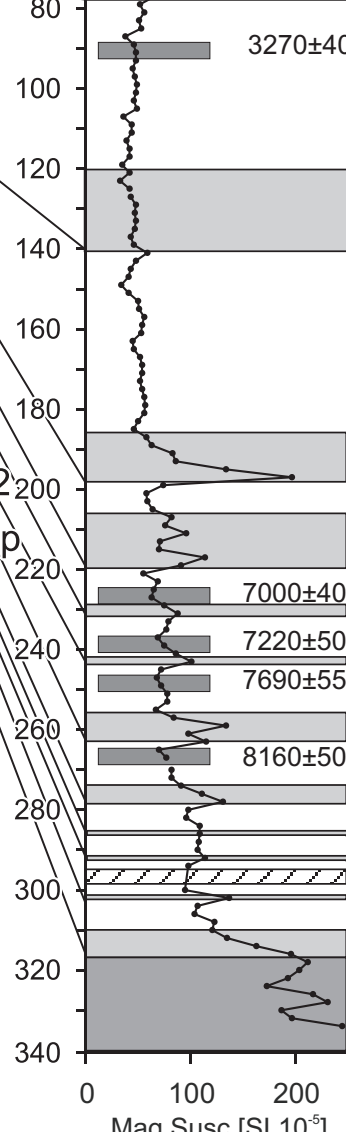

https://mc06.manusforjptcęBtral.com/cjes-pMubgsSusc [SI 10 $\left.10^{-5}\right]$ Mag Susc [SI 10 $\left.0^{-5}\right]$

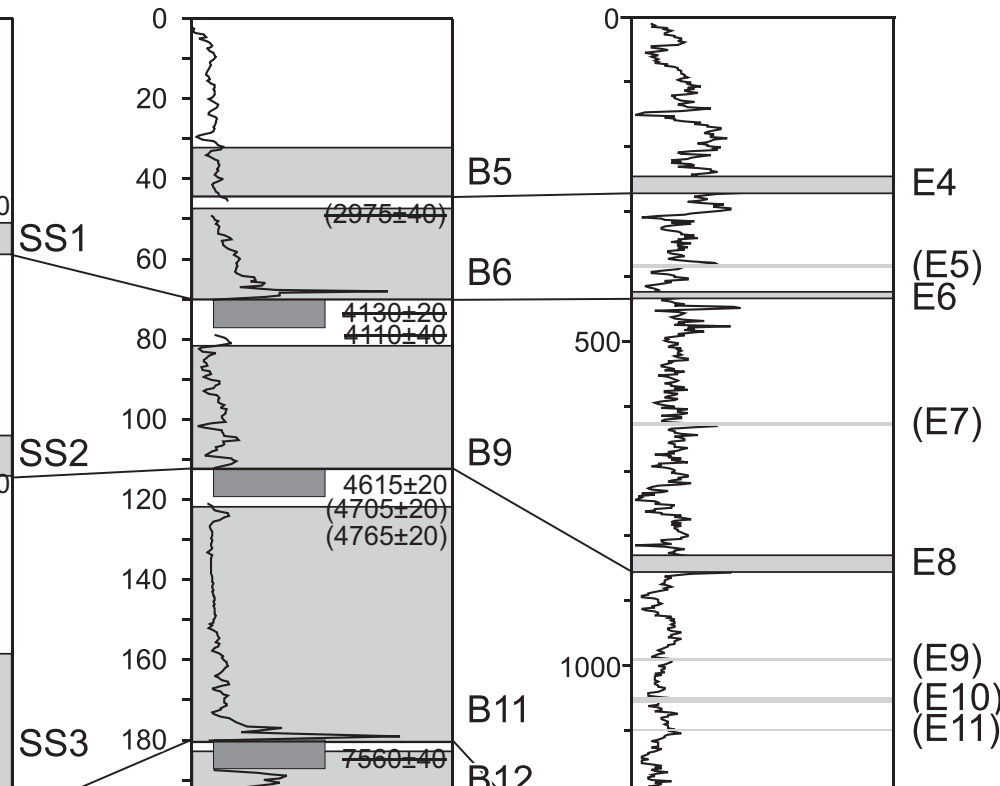

MD02-2494

E12

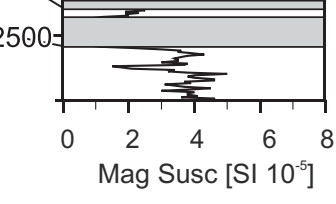


Fig. 5

a

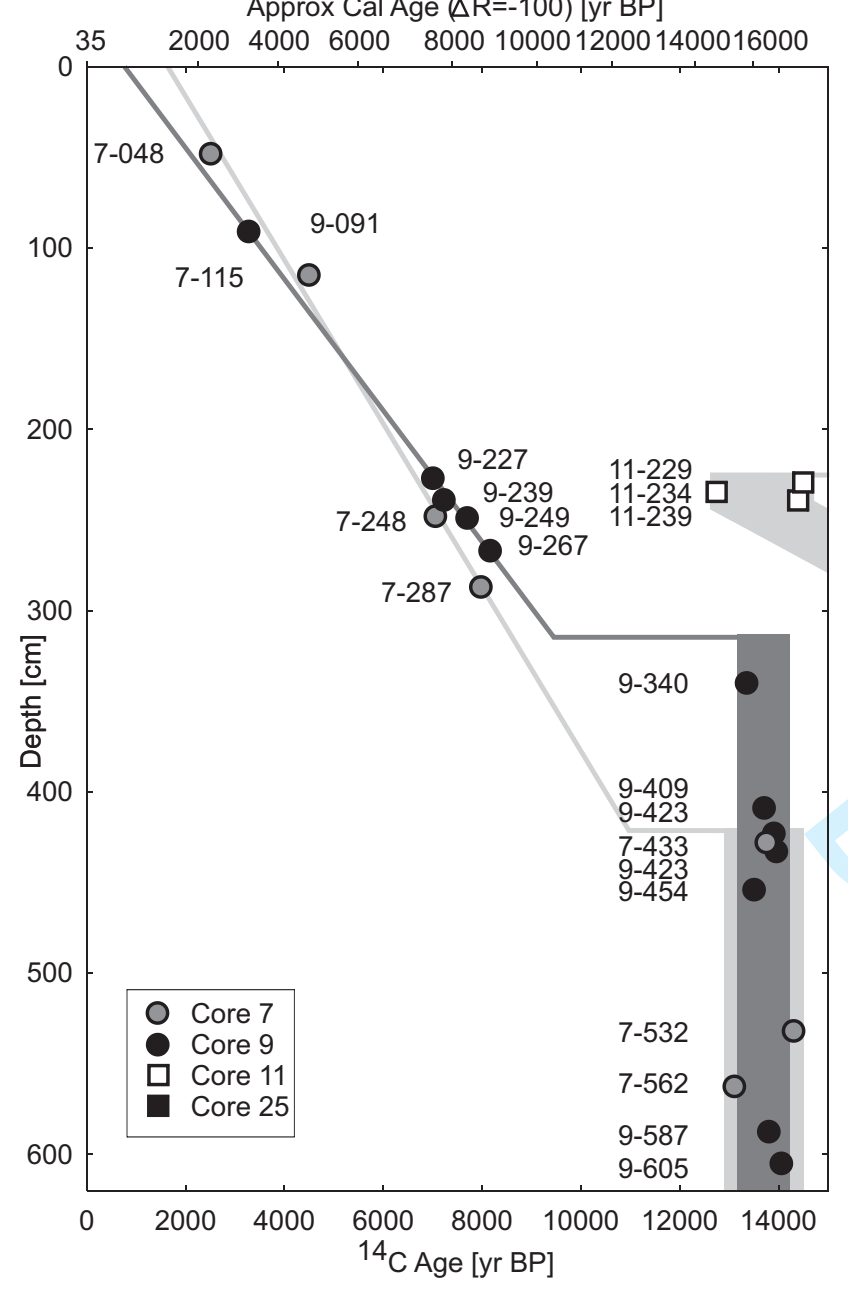

b

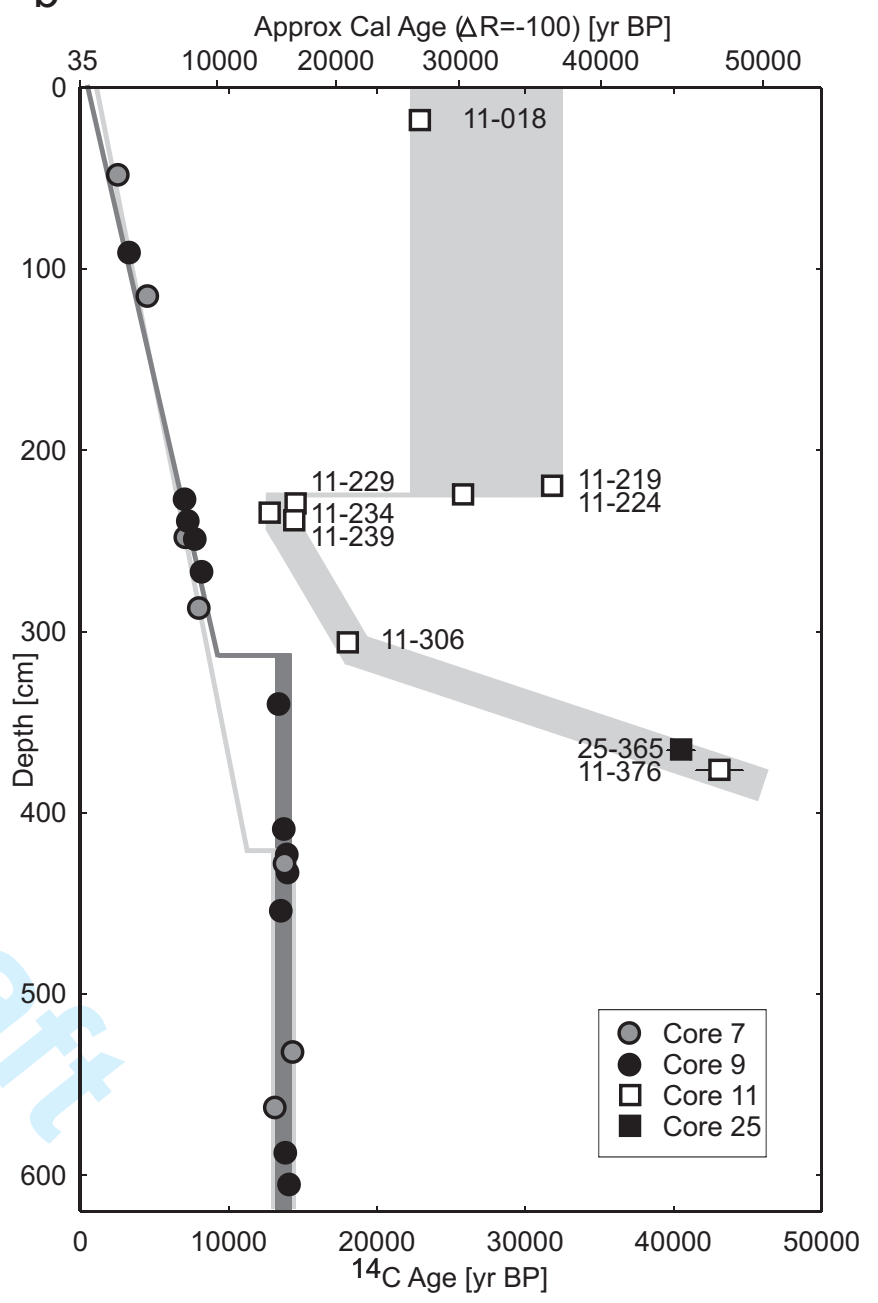



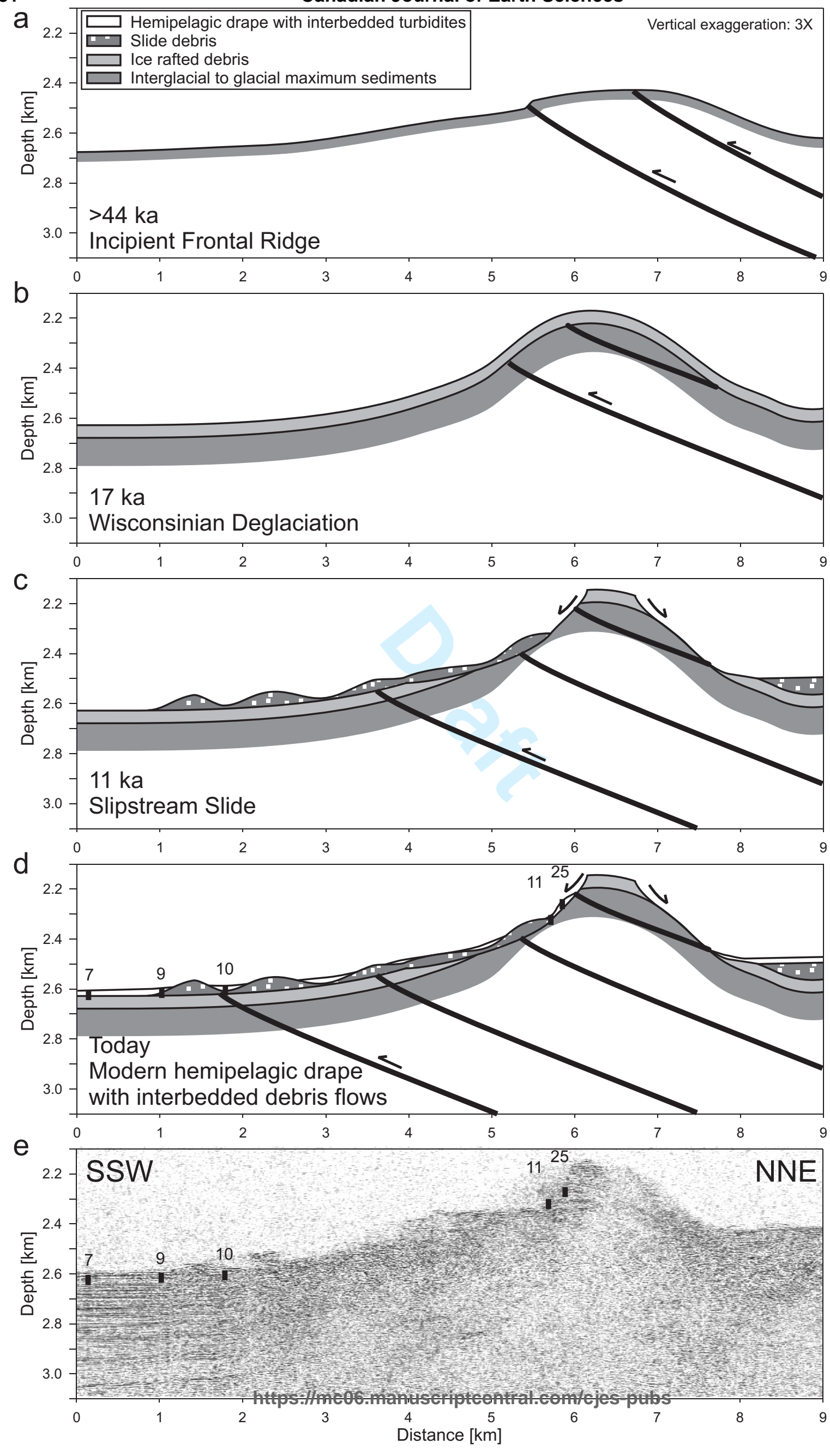
Fig. 7
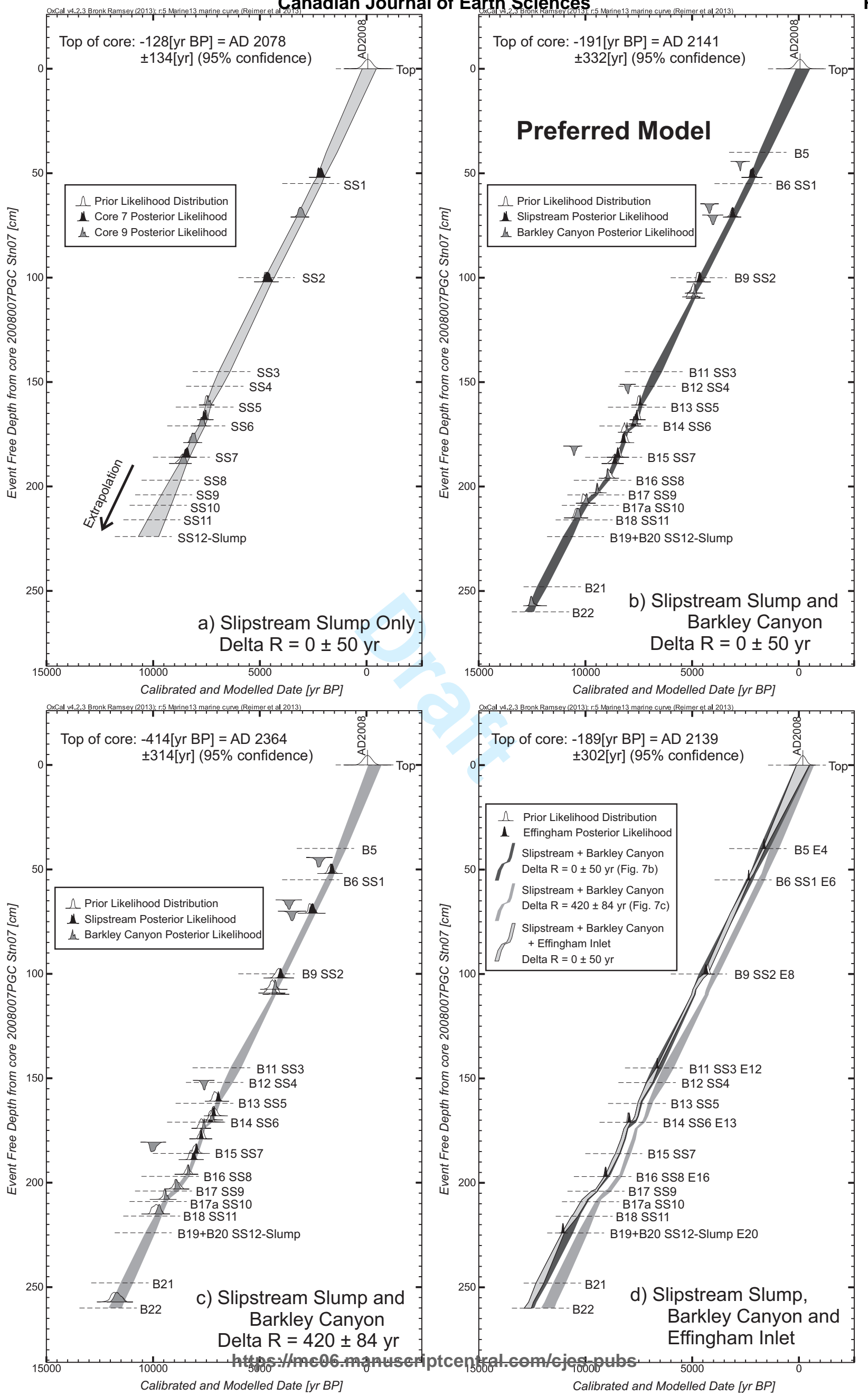


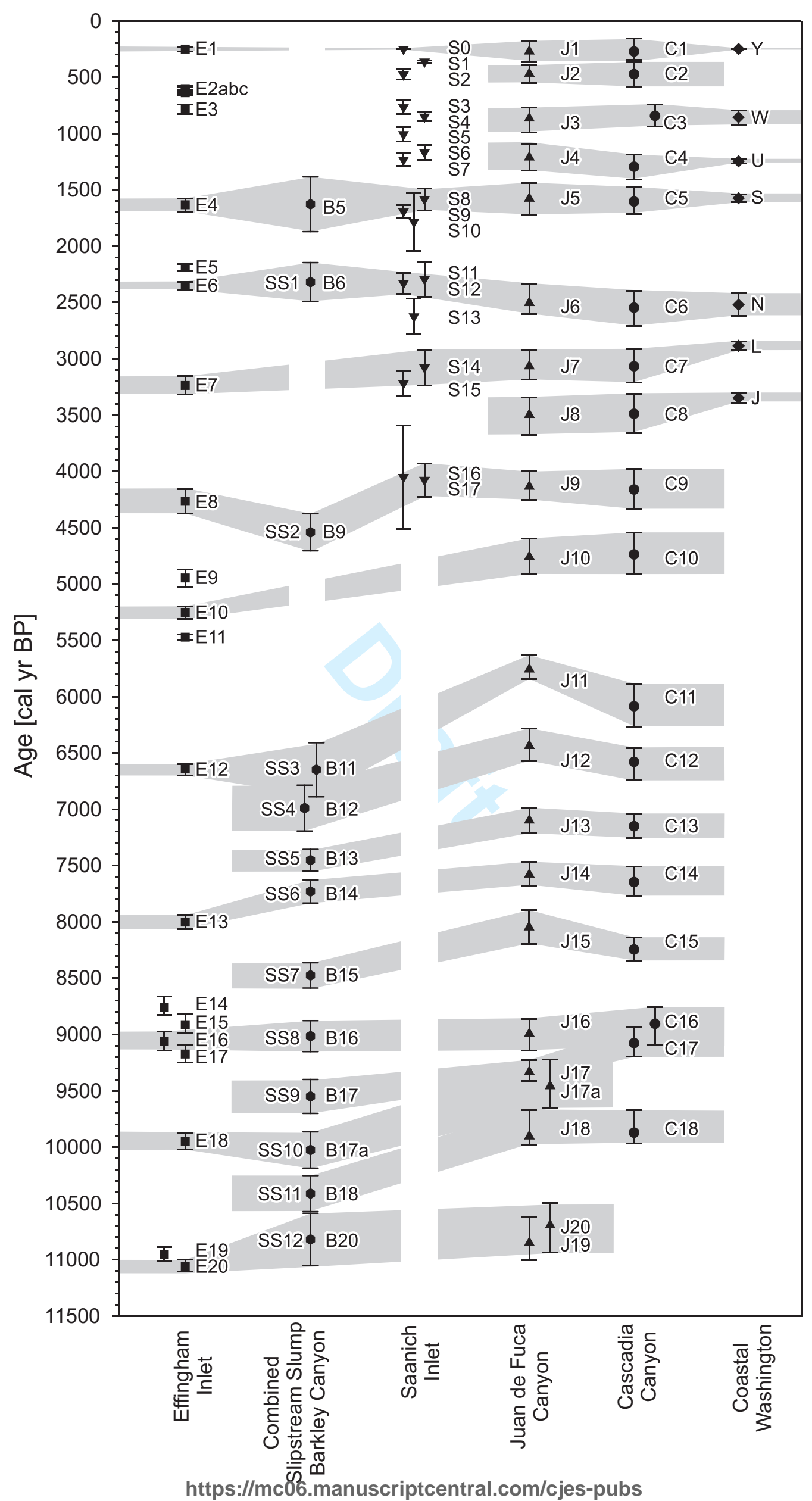


Table 3: Posterior Modelled Dates

\begin{tabular}{|c|c|c|c|c|c|c|c|c|c|c|c|}
\hline \multirow{3}{*}{$\begin{array}{l}\text { Sample or Horizon } \\
\begin{array}{l}\text { Top (AD2008 } \pm 2001 \sigma) \\
\text { E4-B5 }\end{array}\end{array}$} & \multirow{2}{*}{$\begin{array}{c}\text { EFD } \\
{[\mathrm{cm}]}\end{array}$} & \multicolumn{2}{|c|}{$\begin{array}{l}\Delta \mathrm{R}=0 \pm 50 \\
\text { Slipstream } \\
95 \% \mathrm{Cl} \\
{[\mathrm{cal} \mathrm{yr} \mathrm{BP]}}\end{array}$} & $\begin{array}{c}\Delta \mathrm{R}=420 \pm 84 \\
\text { Slipstream } \\
95 \% \mathrm{Cl} \\
\text { [cal yr BP] }\end{array}$ & \multicolumn{2}{|c|}{$\begin{array}{c}\Delta \mathrm{R}=0 \pm 50 \\
\text { Barkley-Slipstream } \\
95 \% \mathrm{Cl} \\
\text { [cal yr BP] }\end{array}$} & \multicolumn{2}{|c|}{$\begin{array}{c}\Delta \mathrm{R}=420 \pm 84 \\
\text { Barkley-Slipstream } \\
95 \% \mathrm{Cl} \\
\text { [cal yr BP] }\end{array}$} & $\begin{array}{c}\text { Effingham } \\
\text { Prior Age } \pm 1 \sigma \\
{[\text { cal yr BP] }}\end{array}$ & \multicolumn{2}{|c|}{$\begin{array}{c}\Delta \mathrm{R}=0 \pm 50 \\
\text { Effingham-Barkley- } \\
\text { Slipstream } 95 \% \mathrm{Cl} \\
{[\text { cal yr BP] }}\end{array}$} \\
\hline & & $-461-$ & 203 & $-677--51$ & -527 & -141 & -715 & $\begin{array}{ll}-91 \\
- & -91\end{array}$ & & -495 & -115 \\
\hline & 40 & & & & & & & & $1633 \pm 30$ & 1578 & - 1694 \\
\hline 07-DE111-109 & 52 & $1990-$ & 2322 & $1475-1790$ & 2029 & -2304 & 1492 & -1756 & & 2119 & -2290 \\
\hline E6-B6-SS1 & 55 & & & & & & & & $2353 \pm 18$ & 2316 & -2389 \\
\hline 09-EF38-34 & 71 & $2883-$ & 3272 & $2355-2701$ & 2941 & -3234 & 2372 & - 2681 & & 2980 & - 3223 \\
\hline E8-B9-SS2 & 100 & & & & & & & & $4265 \pm 55$ & 4259 & - 4457 \\
\hline 07-DE44-42 & 102 & $4440-$ & 4828 & $3844-4220$ & 4506 & - 4779 & 3880 & -4150 & & 4472 & - 4710 \\
\hline 09TC-CASC52 & 107 & & & & 4806 & -4975 & 4160 & -4366 & & 4832 & - 4971 \\
\hline 08TC-CASC243 & 109 & & & & 4836 & -5020 & 4228 & - 4413 & & 4874 & - 5018 \\
\hline 09PC-CASC240 & 110 & & & & 4843 & -5030 & 4236 & - 4419 & & 4885 & - 5030 \\
\hline E12-B11-SS3 & 145 & & & & & & & & $6637 \pm 23$ & 6594 & - 6684 \\
\hline 09-DE44-40 & 161 & $7285-$ & 7535 & $6796-7071$ & 7319 & - 7509 & 6834 & - 7057 & & 7386 & - 7526 \\
\hline 07-CD61-59 & 168 & $7462-$ & 7711 & $7036-7269$ & 7507 & - 7675 & 7076 & -7250 & & 7544 & - 7691 \\
\hline 08TC-CASC239 & 170 & & & & 7586 & - 7758 & 7171 & - 7331 & & 7630 & - 7785 \\
\hline 09-DE32-28 & 171 & $7571-$ & 7840 & $7168-7400$ & 7630 & -7829 & 7225 & -7403 & & 7695 & - 7925 \\
\hline E13-B14-SS6 & 171 & & & & & & & & $8000 \pm 33$ & 7885 & - 8017 \\
\hline 09TC-CASC55 & 174 & & & & 7995 & -8184 & 7565 & - 7699 & & 8033 & - 8202 \\
\hline 09-DE22-18 & 179 & $7965-$ & 8275 & $7547-7799$ & 8113 & -8316 & 7661 & - 7841 & & 8158 & - 8340 \\
\hline 07-CD22-20 & 186 & 8291 - & 8588 & $7844-8115$ & 8360 & - 8581 & 7885 & - 8100 & & 8401 & - 8601 \\
\hline 09-DE4-0 & 189 & $8421-$ & 8760 & $7982-8269$ & 8501 & -8744 & 8005 & -8205 & & 8548 & - 8756 \\
\hline 09PC-CASC237 & 196 & & & & 8816 & - 9031 & 8267 & - 8424 & & 8902 & - 9053 \\
\hline E16-B16-SS8 & 197 & & & & & & & & $9062 \pm 41$ & 8984 & - 9119 \\
\hline 09PC-CASC241 & 203 & & & & 9370 & - 9519 & 8744 & - 8986 & & 9409 & - 9519 \\
\hline 09PC-CASC238 & 208 & & & & 9830 & - 10155 & 9284 & - 9490 & & 9904 & - 10159 \\
\hline 09PC-CASC24 & 215 & & & & 10223 & - 10511 & 9569 & - 9889 & & 10301 & - 10567 \\
\hline E20-B19-B20-SS12 & 224 & & & & & & & & $11060 \pm 29$ & 10991 & -11105 \\
\hline 09PC-CAS2 & 257 & & & & 12302 & -12651 & 11369 & -11943 & & 12440 & -12666 \\
\hline
\end{tabular}

EFD: Event-free depth; $\Delta R$ : Marine reservoir correction; Cl: Confidence interval. Poisson Process k-value=2/cm. The preferred model is the combined Barkley Canyon - Slipstream Slump age model using $\Delta R=0 \pm 50$ years. Horizons are labelled as the turbidite identifiactions from each stratigraphy, e.g., E8-B9-SS2 from Effingham, Barkley Canyon and Slipstream Slump respectively. Radiocarbon samples from Slipstream Slump are labelled by StationSection-Depth range, e.g., 07-DE44-42. Radiocarbon samples from Barkley Canyon are labelled by Core-Sample number, e.g., 09TC-CASC52. These notations are the original sample identifiers from the source databases. 
Table 4: Turbidite Ages based on Combined Slipstream Slumo and Barkley Canyon Dates

\begin{tabular}{|c|c|c|c|c|c|c|c|c|c|c|}
\hline \multirow{3}{*}{$\begin{array}{c}\text { Slipstream } \\
\text { Slump } \\
\text { Event } \\
\end{array}$} & \multirow{3}{*}{$\begin{array}{c}\text { Core } 7 \text { depth } \\
{[\mathrm{cm}]}\end{array}$} & \multirow{3}{*}{$\begin{array}{c}\text { Core } 9 \text { depth } \\
{[\mathrm{cm}]}\end{array}$} & \multirow{2}{*}{\multicolumn{2}{|c|}{$\begin{array}{c}\text { Slipstream } \\
95 \% \mathrm{Cl} \\
\text { [cal yr BP] }\end{array}$}} & \multirow{3}{*}{$\begin{array}{c}\begin{array}{c}\text { Correlated } \\
\text { Barkley Canyon } \\
\text { Event }\end{array} \\
\text { B5 }\end{array}$} & \multirow{3}{*}{$\begin{array}{c}\text { Correlated } \\
\text { Effingham Inlet } \\
\text { Event } \\
\end{array}$} & \multicolumn{3}{|c|}{ Combined Age } & \multirow{2}{*}{$\begin{array}{c}\text { Interval } \\
\text { Mean } \pm 95 \% \\
{[\mathrm{yr}]} \\
\end{array}$} \\
\hline & & & & & & & \multirow{2}{*}{$\begin{array}{c}\text { Mean age } \pm 95 \% \\
{[\text { cal yr BP] }}\end{array}$} & \multicolumn{2}{|c|}{$\begin{array}{c}95 \% \mathrm{Cl} \\
{[\mathrm{cal} \mathrm{yr} \mathrm{BP]}}\end{array}$} & \\
\hline & & & & & & & & 1381 & 1866 & $1819 \pm 322$ \\
\hline SS1 & $51-59$ & $58-78$ & 2101 & 2506 & B6 & E6 & $2318 \pm 172$ & 2145 & 2489 & $690 \pm 236$ \\
\hline SS2 & $104-113$ & $120-140$ & 4326 & 4756 & B9 & E8 & $4539 \pm 162$ & 4373 & 4701 & $2222 \pm 204$ \\
\hline SS3 & $158-199$ & $186-198$ & 6397 & 6925 & B11 & E12 & $6649 \pm 242$ & 6405 & 6886 & $2109 \pm 272$ \\
\hline SS4 & $206-225$ & $206-220$ & 6765 & 7214 & B12 & & $6990 \pm 204$ & 6782 & 7187 & $341 \pm 170$ \\
\hline SS5 & $235-242$ & $229-231$ & 7311 & 7562 & B13 & & $7452 \pm 90$ & 7345 & 7536 & $462 \pm 190$ \\
\hline SS6 & $251-272$ & $242-243$ & 7573 & 7842 & B14 & E13 & $7730 \pm 102$ & 7630 & 7835 & $278 \pm$ \\
\hline SS7 & $287-307$ & $256-264$ & 8291 & 8590 & B15 & & $8475 \pm 112$ & 8360 & 8585 & $745 \pm 118$ \\
\hline SS8 & $318-336$ & $273-279$ & 8704 & 9226 & B16 & E16 & $9014 \pm 130$ & 8884 & 9154 & $539 \pm 138$ \\
\hline SS9 & $343-50$ & $285-286$ & 8967 & 9612 & B17 & & $9549 \pm 150$ & 9416 & 9716 & $535 \pm 172$ \\
\hline SS10 & $355-364$ & $292-293$ & 9156 & 9884 & B17a & & $10025 \pm 154$ & 9886 & 10206 & $476 \pm 174$ \\
\hline SS11 & $371-392$ & $301-302$ & 9426 & - 10262 & B18 & & $10411 \pm 166$ & 10256 & 10577 & $386 \pm 158$ \\
\hline \multirow[t]{3}{*}{ SS12 } & $400-426$ & $310-318$ & 9739 & - 10694 & B19+B20 & E20 & $10818 \pm 234$ & 10589 & 11054 & $407 \pm 186$ \\
\hline & & & & & B21 & & $12040 \pm 244$ & 11790 & 12275 & $1222 \pm 254$ \\
\hline & & & & & B22 & & $12648 \pm 216$ & 12410 & 12860 & $607 \pm 230$ \\
\hline
\end{tabular}

Poisson-process k-value $=2 / \mathrm{cm}$. Combined Slipstream Slump and Barkley Canyon age model, with marine reservoir $\Delta R=0 \pm 50$ based on age of top of core and correlation with Effingham Inlet events. 